\title{
Movimento social quilombola de Santa Rita do Bracuí: aprendizados na militância e a urgência de um currículo diferenciado
}

\author{
Dissertação de Mestrado
}

Dissertação apresentada como requisito parcial para obtenção do grau de Mestre em Ensino de História (opção profissional) pelo Programa de Pós-Graduação stricto sensu em Ensino de História - ProfHistória - do Departamento de História da PUC-Rio.

Orientador: Prof. Sérgio Hamilton da Silva Barra 


\title{
Maurício Adelino da Silva
}

\section{Movimento social quilombola de Santa Rita do Bracuí: aprendizados na militância e a urgência de um currículo diferenciado}

\begin{abstract}
Dissertação apresentada como requisito parcial para obtenção do grau de Mestre em Ensino de História (opção profissional) pelo Programa de Pós-Graduação stricto sensu em Ensino de História - ProfHistória - do Departamento de História do Centro de Ciências Sociais da PUC-Rio. Aprovada pela Comissão Examinadora abaixo assinada.
\end{abstract}

\author{
Prof. Sérgio Hamilton da Silva Barra \\ Orientador \\ Departamento de História - PUC-Rio
}

Prof ${ }^{a}$ Martha Campos Abreu Departamento de História - UFF

Prof ${ }^{\text {a }}$ Ivana Stolze Lima

Setor de História - Fundação Casa de Rui Barbosa

Prof. Augusto César Pinheiro da Silva

Vice-Decano de Pós-Graduação do Centro de Ciências Sociais - PUC-Rio

Rio de Janeiro, 21 de novembro de 2018 
Todos os direitos reservados. É proibida a reprodução total ou parcial do trabalho sem autorização da universidade, do autor e do orientador.

Maurício Adelino da Silva

Graduou-se em História pela PUC-Rio em 2008. Cursou especialização em História da África e do Negro no Brasil pela Universidade Cândido Mendes em 2014. É professor de História no Município de Angra dos Reis desde 2011.

Ficha Catalográfica

Silva, Maurício Adelino da

Movimento social quilombola de Santa Rita do Bracuí: aprendizados na militância e a urgência de um currículo diferenciado / Maurício Adelino da Silva ; orientador: Sérgio Hamilton da Silva Barra. - 2018.

137 f. : il. color. ; $30 \mathrm{~cm}$

Dissertação (mestrado)-Pontifícia Universidade Católica do Rio de Janeiro, Departamento de História, 2018.

Inclui bibliografia

1. História - Teses. 2. Quilombo. 3. Educação quilombola. 4. Currículo. 5. Identidade e memória. I. Barra, Sérgio Hamilton da Silva. II. Pontifícia Universidade Católica do Rio de Janeiro. Departamento de História. III. Título. 
A todos os profissionais de Educação e do Movimento Negro Quilombola que lutam por uma educação pública emancipatória. 


\section{Agradecimentos}

A minha amada esposa, Thaysa, que ao longo dessa jornada foi fundamental, sempre me apoiando, revisando meus trabalhos e discutindo ideias. Sem sua parceria não conseguiria chegar ao final do mestrado.

A minha pequena Maysa que não nasceu ainda, mas já está presente em nossas vidas e irá compartilhar desse momento tão especial.

Aos meus pais, Severino (Biu) e Terezinha (Tereza), que sempre me incentivaram a estudar mesmo não tendo muita escolaridade. Eles perceberam na dificuldade da vida que o conhecimento pode abrir portas para uma vida mais digna. Sempre terei muito orgulho de vocês. Ainda lembro do meu pai chorando e da minha mãe contando, toda orgulhosa, para os amigos e familiares que seu filho havia passado no vestibular. Fui o primeiro da família por causa de vocês, meus amados. Obrigado!

As lideranças quilombolas e educadores que concederam as entrevistas. Esse trabalho é mais de vocês do que meu.

Ao orientador, Sérgio, que foi muito paciente ao ler meu trabalho. As observações sempre foram muito pertinentes e acrescentaram bastante na minha formação.

Aos professores que tive aula ao longo do Mestrado. Os dias de discussões e leituras foram inesquecíveis.

Aos colegas do mestrado que sempre deram força, carinho, compartilharam vivências e conhecimento.

Aos amigos Thayene e Guilherme, pelos dias de encontros e conversas descontraídas.

Ao amigo Paulo que não ficou insistindo para sair.

Aos meus irmãos (Christiano, Crislaine, Micael e Jhonny) pelo carinho e amizade. Vocês são meu orgulho.

A Nayara pela revisão do trabalho.

Ao amigo Felipe pelo resumo em inglês.

Aos amigos que não citei, vocês fazem parte disso, as conversas e conselhos vão nos marcando e formando nossas identidades. Grande abraço em todos e muito obrigado! Amo vocês! 


\section{Resumo}

Silva, Maurício Adelino da; Barra, Sérgio Hamilton da Silva. Movimento social quilombola de Santa Rita do Bracuí: aprendizados na militância e a urgência de um currículo diferenciado. Rio de Janeiro, 2018, 137p. Dissertação de Mestrado - Departamento de História, Pontifícia Universidade Católica do Rio de Janeiro.

Esse trabalho está inserido na linha de pesquisa Saberes Históricos em Diferentes Espaços de Memória, do Programa de Pós-Graduação em Ensino de História (ProfHistória). Tem como objetivo principal identificar caminhos para um possível currículo para uma educação escolar quilombola, em especial de História, na Escola Áurea Pires da Gama. É importante partir da compreensão de que o movimento social quilombola, de uma forma geral, e o movimento social de Santa Rita do Bracuí, em particular, têm uma dimensão pedagógica que demanda uma educação diferenciada: uma educação quilombola. Esse tema se torna urgente no tempo presente onde as burocracias educacionais buscam uniformizar os espaços escolares com a justificativa de estarem democratizando o acesso ao conhecimento. Por outro lado, vários grupos sociais, dentre os quais os quilombolas, exigem uma educação diferenciada que atenda às suas demandas sociais. Uma Educação quilombola pressupõe pensar um currículo quilombola, ou seja, um currículo que leve em consideração interesses e saberes da comunidade quilombola de Santa Rita do Bracuí.

\section{Palavras-chave}

Quilombo; Educação quilombola; Currículo; Identidade e Memória. 


\section{Abstract}

Silva, Maurício Adelino da; Barra, Sérgio Hamilton da Silva (Advisor). The Quilombola Social Movement of Santa Rita do Bracuí: learning in militancy and the urgency of a differentiated curriculum. Rio de Janeiro, 2018, 137p. Dissertação de Mestrado - Departamento de História, Pontifícia Universidade Católica do Rio de Janeiro.

This work is part of the Historical Knowledge in Different Spaces of Memory research line of the Post-Graduate Program in Teaching History (ProfHistória). Its main objective is to identify ways for a possible curriculum for quilombola school education, especially of History, at the Áurea Pires da Gama school. It is important to start from the understanding that the quilombola social movement, in general, and the social movement of Santa Rita do Bracuí, in particular, has a pedagogical dimension that demands a differentiated education: a quilombola education. This issue becomes urgent in the present time when the educational bureaucracies seek to standardize school spaces with the justification that they are democratizing the access to knowledge. On the other hand, several social groups, among which the quilombolas, require a differentiated education that meets their social demands. A quilombola Education presupposes thinking of a quilombola curriculum, a curriculum that takes into consideration the interests and knowledge of the quilombola community of Santa Rita do Bracuí.

\section{Keywords}

Quilombo,; Quilombola education; Curriculum; Identity and Memory. 


\section{Sumário}

$\begin{array}{ll}\text { Introdução } & 9\end{array}$

Capítulo I - Entre o passado e o presente: "Velhas lutas, jovens

histórias." 22

1.1 Trajetória dos remanescentes de Santa Rita do Bracuí 22

1.2 As disputas pela terra: A sobrevivência do território 30

1.3 "Quilombo, o que é isso?" 41

Consideração finais $\quad 51$

Capítulo II - Dimensão Pedagógica do Movimento Social 52

2.1 Movimento Negro e Movimento Quilombola 58

2.2 Aprendizados na Militância negra e quilombola 61

2.3 Memória e Identidade 69

Considerações Finais $\quad 82$

Capítulo III - Áurea Pires da Gama: Educação Escolar Quilombola e um Currículo em Construção 84

3.1 Escola Áurea Pires da Gama e Educação Escolar Quilombola $\quad 87$

3.2 Desafios para uma Educação Quilombola na Escola Áurea Pires da Gama 95

3.3 Urgência de um Currículo Diferenciado 109

$\begin{array}{ll}\text { Considerações Finais } & 127\end{array}$

$\begin{array}{ll}\text { Conclusão } & 128\end{array}$

$\begin{array}{ll}\text { Referências Bibliográficas } & 131\end{array}$ 


\section{Introdução}

Em 2011 iniciei minha primeira experiência como professor de História na Escola Municipal Áurea Pires da Gama. Essa escola fica dentro do território do Quilombo Santa Rita do Bracuí, no município de Angra dos Reis. Assim que cheguei à escola fiquei sabendo dessa peculiaridade do espaço escolar e social no qual estava me inserindo. Essa situação aumentou minha apreensão quanto à nova experiência de, finalmente, me tornar um professor. Por outro lado, estava muito curioso de compreender o contexto social, cultural e escolar desse novo universo. Em outras palavras, meu espaço de futura experiência escolar ampliava o meu horizonte de expectativa.

Após o primeiro ano de experiência e de adaptação à nova rotina de docente, passei a refletir acerca das problemáticas que tornavam a escola Áurea Pires da Gama um espaço tão difícil de trabalhar. Um local com uma grande rotatividade de professores e onde tudo parece chegar por último e em menor número. Inaugurada em 1972, com o objetivo de atender aos moradores locais, que, na sua maioria, eram quilombolas e caiçaras, ou seja, alunos de camadas populares. A escola fica localiza na Rodovia Governador Mário Covas (RioSantos), Km 500, no Bairro Santa Rita do Bracuí, um bairro pobre e afastado do Centro do município de Angra dos Reis.

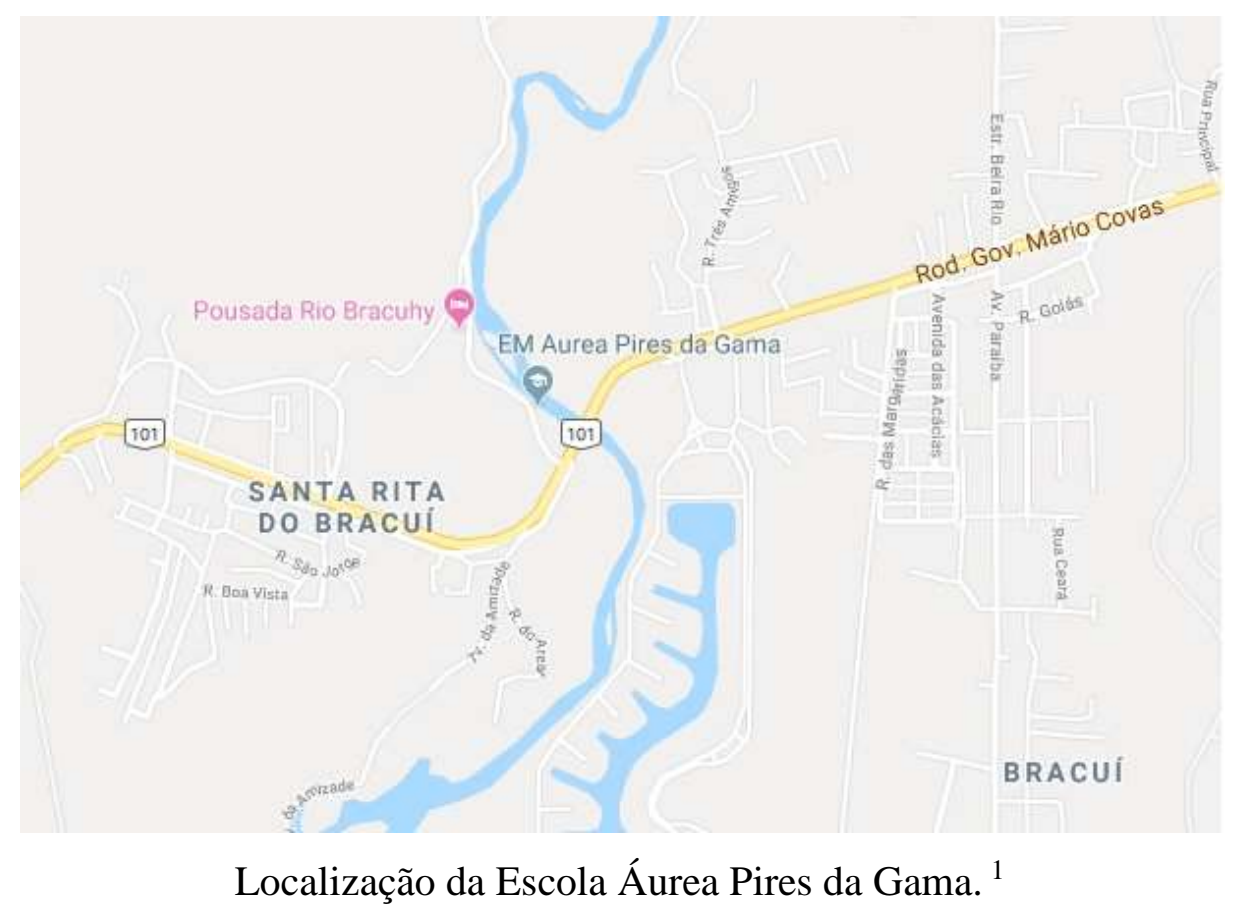

${ }^{1}$ https://www.google.com.br/maps/@-22.934386,-44.3965863,15z - acessado em 22/11/2018. 
Inicialmente, a escola começou com uma sala e aos poucos foi sendo ampliada na medida em que a população da cidade foi crescendo em função dos inúmeros trabalhadores que migraram para a região nos últimos 40 anos em busca de emprego no estaleiro Brasfels, na Usina Nuclear, na Petrobrás, na construção da Rio-Santos e nos empreendimentos ligados ao turismo. Esse crescimento do bairro mudou completamente o perfil da escola que antes, como já mencionado, atendia a comunidades tradicionais, ligadas ao trabalho no campo. A mesma não possuía muros e era comum o espaço da escola ser cedido para as famílias fazerem festas familiares ou do bairro em seu interior. Além disso, a ampliação se realizou ao longo de vários governos, isto é, sem projetos, com adaptações e improvisos. Por consequência desse processo de crescimento e adaptações, a escola sofre com problemas na parte elétrica, na captação do seu esgoto, dentre outros tantos problemas estruturais. Atualmente, segundo informações da direção, a escola tem 596 alunos frequentando, dentre os quais 39 são oriundos do quilombo. Esse número de alunos quilombolas não é preciso, já que se baseia no quantitativo de crianças que usam o ônibus escolar do quilombo para a escola, pois existem crianças no quilombo que não usam o ônibus escolar. Segundo dados informados no Projeto Político Pedagógico (PPP), que ainda está sendo discutido na escola, havia 95 alunos quilombolas em 2017. A escola está distribuída entre vinte turmas, em treze salas de aula (duas sem condições de uso) e em dois turnos (manhã e tarde). Importante salientar que o número de alunos já foi até maior, assim como o de turnos, uma vez que no ano passado (2017) havia a modalidade de Educação de Jovens e Adultos (EJA) que funcionava no noturno. Segundo o Censo de 2017 havia 118 alunos matriculados no EJA. ${ }^{2}$

A ausência de políticas públicas de inúmeros governos levou ao crescimento desordenado e ao aumento da violência na cidade de Angra dos Reis. Esse aumento afetou profundamente os moradores do bairro do Bracuí que sofrem com guerras do tráfico. A violência levou à construção de um muro na escola, porém, essa medida não foi suficiente para inibir as inúmeras invasões de criminosos que, todos os anos, furtam os poucos objetos da escola e vandalizam o espaço com ameaças e depredações, sempre à noite, após o fechamento da escola. Recentemente, em um intervalo de dois meses, uma professora teve dois carros

\footnotetext{
${ }^{2}$ Disponível em: https://www.qedu.org.br/escola/171567-em-aurea-pires-da-gama/censo-escolar. Acesso em: 14/10/2018.
} 
roubados na porta da escola. Após esse problema, a Secretaria de Educação se reuniu com a escola e tomou a decisão de transferir o EJA para um bairro vizinho. Também recentemente a diretora da escola pediu afastamento do cargo após ser ameaçada de morte por pichações feitas na última invasão.

Os problemas ocorridos na escola Áurea Pires da Gama, são recorrentes nas escolas públicas do Brasil. Uma escola sucateada não condiz com a ideia de transformar os alunos para a cidadania, mas tem um efeito negativo nesse processo de ensino-aprendizagem, uma vez que aos alunos, cotidianamente, é ofertado um local com sujeira, sem funcionários, sem professores, sem materiais, etc. Isto é, espaços e situações cotidianas que acabam por reforçar e aprofundar desigualdades. As camadas populares continuam sendo lesadas em um de seus direitos básicos, uma educação de qualidade que atenda às mais variadas demandas da sociedade e dos diversos grupos sociais. Sendo assim, se torna imprescindível entender essa realidade social e pensar em políticas públicas adequadas à realidade desses alunos tão diretamente atingidos pelo processo de desigualdade social.

Além da questão estrutural, uma das problemáticas que mais me chamou a atenção na Escola foi o desconhecimento dos alunos sobre a história local, em especial, a luta do negro no bairro do Bracuí. Soma-se a isso o fato de boa parte negar qualquer identidade negra em função do racismo tão incrustado em nosso tecido social. Há uma luta do movimento quilombola do Bracuí pela titulação de suas terras, por políticas voltadas para os negros, e de uma escola quilombola que atenda às suas demandas, como a construção de uma história que possibilite a valorização da memória, identidade e cultura dos povos negros.

Ao mesmo tempo, sentia a necessidade de aprofundar meus conhecimentos para pensar em estratégias de intervenção no espaço escolar que possibilitassem um aprendizado para um despertar crítico. Nesse sentido, o mestrado profissionalizante trouxe a oportunidade de produzir um trabalho voltado para pensar a realidade escolar em que estou inserido, de compreender a trajetória do movimento quilombola do Bracuí e sua luta por uma educação quilombola.

Essa temática se fez ainda mais presente quando a escola Áurea Pires da Gama passou a ser caracterizada no último Censo, ao final de 2015, como Escola Quilombola. Isso ocorreu após um longo debate de seus funcionários junto à Secretária Municipal de Educação. Essa questão surgiu após o movimento 
quilombola ter oferecido um curso de formação continuada junto a professores da Universidade Federal Rural do Rio de Janeiro - UFRRJ, com duração de aproximadamente dois anos, para os professores da escola Áurea Pires da Gama. Esses temas serão retomados nos capítulos que se seguem com mais detalhes. Nesse momento é importante seu conhecimento para nos situar quanto ao interesse pelo tema.

Daí surgiu com grande força a necessidade de compreender, também, o que significa ser uma escola quilombola para os agentes envolvidos nesse processo, seja por parte dos movimentos quilombolas, dos agentes construtores de normatizações, ou por parte dos professores, que na sua maioria, não tem nenhuma relação com o movimento negro quilombola local. Essa questão fez emergir o tema dessa dissertação. Tendo como principal objetivo identificar caminhos para a construção de um currículo escolar quilombola, em especial, o de História, na Escola Áurea Pires da Gama. É importante deixar claro que nesse trabalho não tenho como pretensão propor um currículo para a escola em questão.

Outras questões também se fazem importantes devido à estreita relação entre passado e presente: de que maneira se constituiu o movimento negro dos remanescentes da comunidade quilombola de Santa Rita do Bracuí? Como a comunidade resiste territorialmente e culturalmente nesse município? Como esse movimento ressignificou a identidade coletiva e individual de seus membros, na medida em que começaram a participar do movimento negro quilombola? Como a Escola Áurea Pires da Gama se torna um espaço importante na luta pela demarcação de suas terras, por uma educação quilombola e por uma memória pública?

Outra questão, que foi se delineando a partir de leituras e discussões do Profhistória, foi a dimensão pedagógica da comunidade e do movimento social quilombola. Ou seja, os conhecimentos da comunidade e da militância são fundamentais para se pensar uma educação diferenciada. Nesse sentido, é importante compreender como os saberes na militância política se constituem na vida em comunidade. Saberes esses, que servirão como elementos de empoderamento para a reivindicação de uma educação diferenciada. Portanto, para alcançar esse objetivo, analisarei trabalhos acadêmicos no campo da educação diferenciada, em especial, os que tratam da educação quilombola. 
Torna-se importante para a pesquisa, ainda, na identificação das especificidades de uma educação quilombola e no entendimento da documentação que normatiza e, portanto, abre precedentes à luta por políticas públicas para a implementação desta modalidade, a leitura das Diretrizes Curriculares Nacionais para a Educação Escolar Quilombola na Educação Básica (BRASIL, 2012). Soma-se à pesquisa, a realização de entrevistas com militantes do quilombo do Bracuí e de professores da Escola Municipal Áurea Pires da Gama para compreender as singularidades, as convergências e as divergências no processo de construção de uma educação quilombola na escola mencionada.

Esse trabalho tenta elaborar um conhecimento alinhado ao pensamento do sociólogo Boaventura de Souza Santos, de produzir uma epistemologia que se contraponha as exclusões sociais. É caracterizada pelo autor como uma epistemologia do Sul. O autor chama a atenção para o fato de essas exclusões estarem alicerçadas no pensamento moderno ocidental, denominada pelo autor de epistemologia do Norte ou de pensamento abissal. O pensamento abissal é, segundo o autor, um sistema de distinções visíveis e invisíveis que atravessam todo o tecido social. A construção de um pensamento pós-abissal é fundamental para desconstruir essa epistemologia do Norte e, assim, abrir precedentes para um mundo alicerçado em uma ecologia de saberes. O movimento quilombola, quando lança o projeto de uma educação quilombola, passa a propor uma nova epistemologia educacional.

Nesse sentido, o meu trabalho se torna importante porque busca contribuir para estudos que pretendam dar visibilidade à história do negro no Brasil, mostrando seu protagonismo, suas tradições, suas lutas, conquistas e seus aprendizados na militância política. Poucos trabalhos vão na direção de compreender a participação no movimento social como uma dimensão importante do processo educacional. Diversos aprendizados são adquiridos na militância, como o político, social, cultural, ético, dentre outros. Estes aprendizados da militância política possibilitam um empoderamento importante na luta por uma sociedade multicultural e menos desigual.

A história do Brasil é marcada por um projeto de Nação branca, explícito na política de incentivo do governo à imigração de brancos para o Brasil. O objetivo era embranquecer a população. Na década de 1930, cientistas afirmam não haver inferioridade biológica entre negros e brancos. Cabe lembrar que nunca 
foi comprovada, cientificamente, superioridade dos brancos em relação aos negros. Esses estudos fazem suscitar um forte discurso antirracialismo, porém, não houve uma política antirracista. A não adoção de políticas antirracistas se deu com base no argumento de que o Brasil era uma sociedade miscigenada, onde todos conviviam de forma harmoniosa, não havendo, por isso, necessidade de políticas de reparação. A condição social era associada às capacidades e não às desigualdades provocadas pelo preconceito racial. O mito da democracia racial de Gilberto Freyre ainda é invocado por muitos indivíduos, pois suas visões são formatadas pela sociedade historicamente racializada em que vivem. Embora a branquitude não seja mais uma política oficial de Estado, ela ainda permanece permeando as relações sociais e visões de mundo. Os contextos sociais racializados impõem uma visão de mundo que precisa ser combatida para pôr fim ao mito da democracia racial e à preponderância da branquitude.

A história de exclusão e exploração do negro abre precedente para embates em torno da responsabilidade desses atos. Alguns opositores às políticas de reparação partem do pressuposto de que esse cenário racista diz respeito ao passado, ao firmarem que somos socialmente iguais e casos de racismo são casos isolados. No entanto, o movimento negro e quilombola evocam a memória da escravidão, da exclusão do negro no Brasil e de sua militância, para demonstrar não se tratar de algo pretérito, tendo em vista que suas mazelas, dentre elas o racismo, ainda estão no tempo presente. Há nessa discussão uma disputa em torno dos usos da memória da escravidão e do negro no Brasil. Essa disputa esconde relações de poder e de dominação de grupos que sempre foram beneficiados em detrimento de minorias.

Pelos motivos expressos, se faz extremamente necessário fazer uma reflexão acerca das motivações e implicações da exigência do movimento quilombola por uma escola diferenciada. Estudos que reflitam acerca de uma educação escolar quilombola são muito recentes, assim como a implementação de escolas quilombolas. Desconheço escolas quilombolas que tenham um currículo estabelecido, boa parte delas ainda está gestando seus currículos. Nesse sentido, é interessante para o desenvolvimento de uma educação inclusiva, democrática e multicultural a reflexão das especificidades de um currículo para uma educação quilombola no Bracuí, em especial, o de História. 
Pereira (2012) chama a atenção para o fato da história do Brasil ser marcada pelo papel ativo dos negros por escolarização, ou seja, pelo domínio da escrita e leitura, além da participação de negros letrados no processo abolicionista e pós-abolicionista, ainda que tais assuntos sejam silenciados nos currículos prescritivos. Essa luta não se restringiu apenas ao direito ao acesso dos negros à educação, mas, em especial, à história ensinada nas escolas como uma ferramenta importante para a revisão do papel do negro ao longo da história do Brasil. A história do movimento negro demonstra a importância dada à educação para alcançar essa reavaliação do protagonismo negro na história.

Bem antes, a Frente Negra Brasileira (FNB), criada em São Paulo em 1931, e o Teatro Experimental do Negro (TEN), criado na mesma cidade em 1944, duas das mais importantes organizações do movimento negro na primeira metade do século XX, já contavam com escolas em suas dependências para alfabetizar e instruir pessoas negras. (PEREIRA, 2012, p. 114)

A constituição de 1988 estabelece que o Ensino da História do Brasil tenha como referência as contribuições das diferentes culturas e etnias para a formação do povo brasileiro. Ao longo da década de 1990, começam a aparecer nas normatizações do MEC as noções de cultura, diversidade cultural, identidade e relações étnico-raciais. Isso não seria possível sem o protagonismo do movimento negro que parece ter percebido que as normatizações são campos de disputa importantes para a adoção de possíveis políticas educacionais inclusivas. O processo de construção do currículo, principalmente o de História, passa a ser para o movimento negro um instrumento importante de revisão do papel do negro na História do Brasil. O movimento quilombola vai além da inclusão da História da África e das relações étnico-raciais no Brasil, pois passa a exigir uma educação quilombola.

Um dos instrumentos importantes para a realização da pesquisa foi o arcabouço teórico da História Oral, que é “[...] é um ramo da história pública, gênero que se compromete com a comunidade que gera e consome a própria história. História oral, portanto, tem um fundamento político exposto em sua razão de ser." (MEIHY, 1994 p. 55). Está fortemente ligada à memória coletiva de grupos historicamente marginalizados no Brasil e tem sido uma ferramenta importante na luta por um dever de memória. Nesse sentido, tem uma dimensão 
de produzir uma história pública como sendo um direito que por tanto tempo foi negado às minorias, aqui em especial, aos quilombolas.

Segundo Meihy (1994), a História Oral pode ser dividida em história oral híbrida, que combina depoimento com outras fontes e história oral pura que cuida apenas dos testemunhos. Essa pesquisa pretende navegar de acordo com as necessidades, seja pela híbrida ou pura. Também pretendo me utilizar da história oral temática, pois os testemunhos terão o objetivo de desenvolver o tema. A história oral temática passa por uma dimensão individual, mas com o objetivo de pensar questões relacionadas à trajetória do grupo e suas demandas do tempo presente, como a educação quilombola e seus desdobramentos, em especial no campo do currículo de história para uma educação quilombola.

Para mim não há diferença fundamental entre fonte escrita e fonte oral. A crítica da fonte, tal como todo historiador aprende a fazer, deve, a meu ver, ser aplicada a fontes de tudo quanto é tipo. Desse ponto de vista, a fonte oral é exatamente comparável à fonte escrita. Nem a fonte escrita pode ser tomada tal e qual ela se apresenta. (POLLAK, 1992, p.207).

As fontes materiais e orais não serão utilizadas como meios de acessar o passado diretamente, mas como meios de buscarmos indícios para se representar esse passado. Esta futura narrativa não tem pretensão de apresentar esse passado como uma realidade inquestionável ou verdadeira. Por outro lado, tentarei produzir uma narrativa que se pautará na análise crítica da realidade social estudada.

A compreensão das diversas aprendizagens construídas na militância política do quilombo passa pela análise de trabalhos nessa perspectiva, mas, fundamentalmente, por entrevistas. Além disso, ela se faz também necessária quando adentramos nas análises do que se entende como educação escolar quilombola, para os quilombolas e para os docentes. As entrevistas são importantes para diagnosticar conflitos, resistências e se há, ou não, políticas públicas na escola Áurea Pires da Gama com base nas diretrizes para uma educação escolar quilombola. As entrevistas realizadas se caracterizam como semi-estruturadas, ou seja, tiveram um roteiro com o objetivo de sistematizar a pesquisa, porém, o entrevistado não foi tolhido de um diálogo mais aberto, ficando à vontade para dialogar no desenrolar da entrevista. 
Foram entrevistadas dez pessoas, dentre as quais estão três lideranças do movimento negro quilombola do Bracuí e sete profissionais da Escola Áurea Pires da Gama. As lideranças foram escolhidas levando em consideração a participação na militância por uma educação quilombola. As entrevistas das lideranças ocupam um papel extremamente importante para compreender como se constituem as aprendizagens no movimento negro quilombola, como, por exemplo, a percepção da necessidade de uma educação diferenciada, ou melhor, de uma educação quilombola. Entrevistar os professores nos permitiu adentrar nos muros da escola e compreender como vem se dando esse processo de tentativa de construir uma educação escolar quilombola. Os depoimentos de lideranças negras no livro "História do Movimento Negro no Brasil" 3 trarão para a discussão elementos importantes na compreensão do caráter pedagógico do movimento negro, como a ressignificação das suas identidades, o estabelecimento de estratégias na luta contra o racismo, por igualdade e justiça social.

Dentre os profissionais da educação foram escolhidos membros da equipe gestora que acompanharam e participaram ativamente dos momentos de discussão acerca da temática. Alguns critérios foram utilizados para a escolha dos professores, dentre os quais o fato de ser professor de História ou de disciplinas de humanas, a postura de questionamento ao processo que levou a escola a se tornar quilombola e a disponibilidade do professor para conceder a entrevista. Além disso, um dos educadores entrevistados começou a trabalhar na escola após a caracterização da mesma no Censo como quilombola. Enfim, o objetivo é dar voz a esses atores e identificar caminhos a seguir nessa empreitada de construção de uma educação quilombola. "Uma das principais riquezas da história oral está em permitir o estudo das formas como pessoas ou grupos efetuaram e elaboraram experiências, incluindo situações de aprendizado e momentos estratégicos". (ALBERTI e PEREIRA, 2007, p.17).

Esse trabalho também tem como um dos seus referenciais teóricos a história local. Essa abordagem foge à visão macrossocial totalizadora. O Brasil é marcado por uma historiografia nacional que se impõe desde o século XIX até o período da ditadura militar brasileira. Essa perspectiva nacional por muito tempo soterrou e apagou as possibilidades de uma história local. Reznik afirma que "não

\footnotetext{
${ }^{3}$ ALBERTI, Verena e PEREIRA, Amilcar Araujo. História do Movimento Negro no Brasil: depoimentos ao CPDOC. Rio de Janeiro: Pallas; CPDOC-FGV, 2007.
} 
podemos, contudo conceituar o que é local pela mera oposição com o nacional." (REZNIK, 2002, p. 3). O micro e o macro se entrecruzam nas redes do tecido social, ora negando, ora se aproximando um do outro. Essa relação permite pensar as diferentes éticas de pertencimento. O local seria um recorte temático dentro de uma escala construída pelo historiador.

Em particular, consideramos a abordagem sob o recorte da história local um campo privilegiado de investigação para os diversos níveis em que se trançam e constituem as relações de poder entre indivíduos, grupos e instituições. Acreditamos também que é no traçado local dessas redes e efeitos de poder que conseguimos construir outras interpretações para os complexos processos de sedimentação de identidades sociais. (REZNIK, 2002, p.4).

A história local possibilita compreender como se constitui o movimento quilombola do Bracuí dentro de suas redes de relacionamentos, tanto entre seus indivíduos, quanto com outros grupos, instituições e governos. Ainda dentro dessa perspectiva de rede, podemos tentar compreender como essas relações estão associadas, ou não, à resistência cultural do grupo em contraponto a uma sociedade global que impõe uma desterritorialidade e homogeneização cultural.

Gonçalves destaca a importância do conceito de escala de observação, empregado na história local, o qual "nos insere no entendimento de que uma fronteira não é o ponto onde algo termina, mas, como os gregos reconheceram, a fronteira é o ponto a partir do qual algo começa a se fazer presente." (GONÇALVES, 2001, p.2). Essa dimensão de escala de observação nos permite conhecer e fazer conhecer o outro, ou seja, atravessar a fronteira para desvelar aquilo que foi silenciado, inferiorizado e esquecido pela historiografia nacional.

Pensar a identidade desse grupo é compreender suas especificidades culturais e suas demandas por políticas de inclusão e de uma memória pública. Reznik aponta para a importância de políticas da memória para a valorização e empoderamento das identidades locais: “A sedimentação de valores identitários nesse sentido, depende de políticas da memória, através dos quais o que é lembrado e o que é esquecido retroalimenta a preservação ou o deslocamento desses mesmos valores." (REZNIK, 2002 p. 4)

Na primeira parte do Capítulo 1 pretende-se compreender a trajetória de luta pela posse da terra e como esses sujeitos se constituíram enquanto quilombolas. Os moradores do quilombo do Bracuí têm nas memórias dos seus antepassados o alicerce que os credenciam à posse sobre a terra e também de suas 
identidades. A apresentação se faz necessária para compreendermos esses sujeitos enquanto atores importantes na luta pela terra, valorização de seus aspectos culturais, contra o racismo e por políticas educacionais adequadas à sua realidade. A história desses sujeitos nos coloca um microcosmo da luta contra o racismo e pela posse da terra, algo tão caro para o Brasil. As trajetórias nos mostram a importância de compreendermos o presente como o desdobramento de outras tantas histórias e tempos. Sem esse pressuposto não há como compreendermos a importância de uma Educação Quilombola para as lutas desses povos, sobretudo, do quilombo de Santa Rita do Bracuí. Cabe ressaltar a relevância do Relatório Antropológico de Caracterização Histórica, Econômica e Sócio-cultural do Quilombo de Santa Rita do Bracuí ${ }^{4}$ na elaboração deste capítulo.

$\mathrm{Na}$ segunda parte do capítulo objetiva-se apresentar o processo de ressemantização do conceito de quilombo. Compreender a disputa em torno deste conceito é compreender as disputas políticas e as relações de poder tão presentes em nossa sociedade. Esse conceito pode abrir novos horizontes de expectativas coletivas às comunidades quilombolas e para o resto do tecido social. A desnaturalização da experiência temporal histórica abriu precedente para novos questionamentos, como os referentes à luta por uma política de reparação aos negros que sofrem com as mazelas do passado escravo. A derrubada desse paradigma é fundamental para compreendermos esses atores como sujeitos históricos que se apropriam e ressignificam suas experiências sociais.

No Capítulo II a discussão parte do pressuposto de que a educação escolar não se limita apenas ao universo escolar, ou seja, à educação formal. $O$ movimento social negro e quilombola, assim como as vivências em comunidades, possibilitam diferentes tipos de aprendizagens e saberes que fazem parte do processo de formação desses sujeitos, individual e coletivamente. É de suma importância identificar os saberes e aprendizados do movimento quilombola para se pensar um currículo diferenciado. Há uma educação não formal nos movimentos sociais tão importante quanto a formal, pois ela configura identidades

\footnotetext{
${ }^{4}$ MATTOS, Hebe e ABREU, Martha e SOUZA, Mirian Alves de e COUTO, Patrícia Brandão. Relatório Antropológico de Caracterização Histórica, Econômica e Sócio-cultural do Quilombo de Santa Rita do Bracuí. Niterói: Universidade Federal Fluminse (UFF)/INCRASRRJ, 2009.
} 
e lança, por muitas vezes, os sujeitos no engajamento da luta por uma sociedade mais justa.

Cada comunidade quilombola tem práticas educacionais tradicionais próprias que permeiam suas organizações sociais. As tradições ou processos de aprendizagem ocorrem na experiência cotidiana com os mais velhos, tendo a oralidade como umas das principais ferramentas da transmissão do conhecimento. A Educação Quilombola propõe uma aprendizagem que leve em conta esses saberes como importantes para uma educação transformadora da realidade social e política. Daí a relevância desses conhecimentos da comunidade e do movimento quilombola de Santa Rita do Bracuí serem incluídos no currículo de uma escola quilombola. Uma educação libertadora, na medida em que não visa uniformizar, mas valorizar esses saberes como algo a ser ensinado e ser aprendido. Portanto, um aprendizado que agrega sentidos, valorização e pertencimento à identidade. A Educação escolar "tradicional" não dá conta dessas demandas porque nega a necessidade de um currículo diferenciado, exigindo um conhecimento distante da realidade social dos quilombolas, e ainda, em alguns casos, reforçando o preconceito sobre os saberes tradicionais e silenciando outros saberes.

No Capítulo III há a tentativa de compreender o processo de construção de uma educação quilombola na Escola Áurea Pires da Gama, apontando possíveis caminhos para um currículo quilombola. As entrevistas corroboram para identificar o que esses sujeitos entendem por educação quilombola, as dificuldades de construção de uma educação diferenciada e as sugestões para um currículo quilombola. As diretrizes para uma educação escolar quilombola compreendem o currículo como uma construção da comunidade escolar, centrado no pluriculturalismo. O currículo de história, segundo as diretrizes quilombolas, exige uma pedagogia centrada nas memórias, nas experiências, nos saberes tradicionais, no movimento e para o movimento, em uma ecologia de saberes, dentre outros tantos elementos que façam parte da experiência das comunidades quilombolas, dos alunos, dos negros e de tantas outras minorias excluídas dos currículos escolares. O currículo de história para uma educação quilombola deve ser norteado pela ideia de positivação das culturas que por tanto tempo foram negadas e silenciadas, em especial, dos negros, e, em particular, dos quilombolas.

Os currículos não são neutros, mas oriundos de relações de força, capazes de criar e recriar identidades e interpretações sociais de acordo com interesses de 
grupos ou particulares. Sendo assim, é urgente a construção de um currículo democrático, capaz de atender às diferentes matrizes culturais formadoras da sociedade brasileira, sem hierarquias e eurocentrismo. Um currículo que contribua para a construção de uma sociedade que aprenda a respeitar e valorizar as diferenças e a pluralidade cultural. O movimento quilombola é contra esse sistema escolar que visa uniformizar, pois luta por uma educação que pensa as especificidades de um povo, não nega a diversidade cultural e nem hierarquiza as diferenças. 


\section{Capítulo I - Entre o passado e o presente: "Velhas lutas, jovens histórias. 95}

Nesse trabalho, contextualizar - ainda que de forma sucinta - torna-se primordial para a compreensão da trajetória de resistência e luta pela posse da terra e, ainda, para o entendimento da constituição desses sujeitos enquanto quilombolas a partir da configuração do território, isto é, do Quilombo. Os moradores do Quilombo do Bracuí remetem-se a seus antepassados para reafirmar a posse sobre a terra e também suas identidades. A compreensão desse contexto de luta é fundamental para a apreensão dos diversos saberes e dos impactos sobre a construção de suas identidades negra e quilombola.

\subsection{Trajetória dos remanescentes de Santa Rita do Bracuí.}

O território hoje propriedade dos descendentes de escravos pertenceu, até o final do século XIX, à renomada e conhecida Família Breves, ou melhor, a José Joaquim de Souza Breves que a adquiriu em maio de 1829 e a nomeou Fazenda Santa Rita do Bracuí. Joaquim José de Souza Breves era irmão de José Joaquim de Souza Breves e tornou-se conhecido como o "Rei do Café" por sua fortuna adquirida no cultivo desse grão no Vale do Paraíba e, pelo comércio ilegal de escravos, no final da primeira metade do século XIX.

No início da década de 1860, 1,5\% de todo o café brasileiro foi produzido em terras da Família Breves. Motivada pela alta lucratividade do comércio de escravos, após a lei brasileira de proibição do tráfico, de 1831, a família Breves entrou nesse comércio e o exerceu por um longo período de tempo. Com a proibição do comércio transatlântico de escravos, os pequenos comerciantes foram impedidos de participarem do negócio devido aos altos custos e riscos que apresentava. Uma reorganização do tráfico ocorreu e nessa nova organização os africanos passaram a ser desembarcados em praias distantes, em locais que não possuíam o controle do Estado, como ocorria anteriormente.

\footnotetext{
5 "Velhas Lutas, jovens histórias" é inspirado no documentário: Bracuí: velhas lutas, jovens histórias. Um documentário produzido pelo "Observatório Jovem do Rio de Janeiro", do Programa de Pós-Graduação em Educação da Universidade Federal Fluminense - UFF, 2007. Direção: Paulo Carrano. O documentário relata a luta da comunidade quilombola de Santa Rita do Bracuí através de entrevistas de jovens e de lideranças experientes da comunidade.
} 
Nas fazendas dos Breves as estruturas para receber recém-escravizados do tráfico ilegal de seres humanos foram recriadas. Os "pretos novos" eram desembarcados às margens das fazendas pertencentes aos Breves em Angra dos Reis e Mangaratiba. Essas fazendas eram organizadas em função do tráfico de escravizados. Provavelmente, suas estruturas ocuparam o lugar do antigo Cais do Valongo como principal porta de entrada de negros escravizados no Rio de Janeiro. A seguir, encontra-se um trecho da entrevista do senhor Manoel Moraes ${ }^{6}$, morador de Santa Rita do Bracuí, no qual ressalta ter sido a fazenda Santa Rita local de desembarque ilegal de africanos escravizados:

\begin{abstract}
Mas aqui era o ponto de embarque e desembarque do Comendador Sousa Breves quando saía e chegava (...). Aqui é um ponto que existia também, além de ser de desembarque, era de engorda também, sabe? Tinha um lugar aí, que eu não posso dizer, onde os escravos quando chegavam, pelos tempos que eles viviam no mar, eles não comiam bem, então perdiam o valor, ficavam magros, emagreciam, ficavam abatidos. Então ficavam sem valor. Então eles escondiam por aqui, não sei aonde é aí, né? Passavam ali uns vinte dias. Quando eles chegavam a (...), carne de novo, aí subia para Santa Rita.

A história que eu sei, (...) que (...), proibiram a venda dos escravos para cá, né? Mas, não sei como é que fizeram, que ainda roubaram lá oportunidade e arrumaram uns escravos para trazer pra cá, para vender novamente, né? Raptaram escravos lá, encheram o navio e trouxeram pra cá. Mas veio até aqui, numa ilha com um nome... Como é? Ilha Cunhambebe. Uma ilha que tem pra trás (...) $\mathrm{O}$ barco entrava lá, passava pertinho (...) para entrar e trazia as pessoas para cá, né? E ali quando observaram, que vinha uma escolta atrás deles, pra prender eles, né? (...) Diz que o navio tem um buraco, tinha um buraco que batia (...) a água, aquele pino saia, né? Saia e abria um buraco e a água invadia. Então foi assim, alguns caiam na água, outro jogava lancha n'água, então salvou bastante e morreu bastante e o barco afundou na ponta da ilha. (LOURENÇO, 2010, p. 125).
\end{abstract}

Os trabalhos de Lourenço (2010) e Mattos, Abreu, Souza e Couto (2009) ${ }^{7}$ associam o depoimento citado acima, como uma possível fonte oral daquilo que ficou conhecido na época como o "Caso do Bracuí" de 1852. Segundo os autores citados, o "Caso do Bracuí" trata-se, possivelmente, do navio negreiro Brique Camargo que foi incendiado pelos traficantes, ainda com escravizados, para evitarem o flagrante do patrulhamento contra o tráfico de escravos. Os traficantes

\footnotetext{
${ }^{6}$ A entrevista faz parte do Acervo Petrobrás Cultura, Memória e Música Negra, Arquivo Audiovisual do Laboratório de História Oral e Imagem do Programa de Pós-Graduação em História da Universidade Federal Fluminense (APCMMN/LABHOI/UFF). Ver também www.historia.uff.br/jongos/acervo.

Esse material deu origem ao documentário "Memórias do Cativeiro" que pode ser encontrado nas páginas http://www.labhoi.uff.brehttps://www.youtube.com/watch?v=_Hxhf $7 \mathrm{wzk} 0$ Acesso: 16/06/2018

${ }^{7}$ MATTOS, Hebe; ABREU, Martha; SOUZA, Mirian Alves e COUTO, Patrícia Brandão. Relatório Antropológico de Caracterização Histórica, Econômica e Sócio-cultural do Quilombo de Santa Rita do Bracuí. Niterói: SE, 2009.
} 
fugiram com os escravizados que já haviam desembarcado. Os irmãos Breves eram os principais responsáveis por abastecerem os fazendeiros da região com o tráfico negreiro. Cabe explicitar que as mortes narradas pelo Sr. Manoel Moraes podem ter sido confundidas com outros casos de navios negreiros na região do Bracuí.

Escravizados pelo comendador José de Souza Breves, os avós maternos e paternos do Sr. Manoel Moraes foram um dos responsáveis por difundirem as histórias do tráfico ilegal de escravos ao longo dos anos na comunidade negra de Santa Rita do Bracuí. Este processo de rememoração confunde a história da fazenda e suas próprias trajetórias. Tal memória circula no imaginário do coletivo quilombola. Dentro da comunidade é recontada para os mais jovens e ainda em apresentações e encontros fora dela. Em consonância com a história dita oficial, porém, contada a partir de outro prisma, daqueles que sofreram e sofrem por conta deste processo tão violento, esse relato se coloca como essencial ao registro histórico dessa comunidade. Nele, seus atores ganham voz e agregam elementos que até então não eram percebidos ou até ocultados pela história "oficial".

Não como meros coadjuvantes, mas como os organizadores e operadores dessa nova e grande estrutura do tráfico ilegal de escravos que funcionava em suas fazendas no litoral Sul Fluminense, esse depoimento, bem como outros existentes na comunidade, confirma a presença dos senhores Breves no tráfico de escravos no Rio de Janeiro. Ponto clandestino de desembarque de escravos e também local onde se preparava os escravos para serem vendidos a altos preços a fazendeiros da região Sul Fluminense caracteriza, portanto, a história do Bracuí e da família escravista que lá vivia. Muitos escravos abatidos, magros e até doentes chegavam e ficavam na fazenda Bracuí, para engordarem, se recuperarem após as longas viagens a que eram submetidos. Somente posteriormente, após se recuperarem, eram enviados para a venda.

Encarregado do engenho da fazenda Santa Rita do Bracuí, portanto, ocupando cargo de extrema importância para o funcionamento dessa rede comercial, Antônio Joaquim da Silva (avô do Sr. Moraes) conheceu de perto o funcionamento do tráfico e presenciou a chegada e a partida de vários desses escravizados. Antônio tinha como função organizar a produção de cachaça que seria trocada no continente africano por novos escravizados. Assim sendo, sua produção estava em função do tráfico negreiro. A associação dessa fazenda ao 
tráfico era tamanha que após o fim deste, a mesma entrou, na década de 1870, em decadência. Nas proximidades de onde foi construída a sede do quilombo do Bracuí as ruínas do antigo engenho ainda podem ser vistas. A escolha do local para construir a sede da comunidade demonstra o quanto a mesma valoriza seu passado histórico.

Contribuindo para a percepção da participação dos Breves no tráfico de escravos, o trabalho de Lourenço (2010) ilustra as várias vezes que os Breves são citados nos autos de investigação, principalmente após a Lei Eusébio de Queiroz de 1850 que proibiu o tráfico de escravos. Evidenciam, ainda, que os comendadores foram os últimos a deixarem o comércio de escravos desembarcando, no período de 15 anos, aproximadamente 4.388 africanos. Os autos em questão mostram, em consonância com o depoimento do Sr. Moraes, as várias investidas do governo contra o tráfico, com destaque para o caso do Brique Camargo de 1852, acontecimento esse que virou notícia dos jornais da época. O caso ganhou tanta repercussão que talvez tenha ficado de maneira mais incisiva na memória dos que a presenciaram ou pode estar associada a outro fato similar.

Em uma avaliação do patrimônio de José Breves, realizada em 1881, a fazenda apareceu em situação de abandono quando comparada a outras fazendas: "Somado o engenho, com os carros de bois e seus respectivos semoventes, destinados ao transporte da cana e seus derivados, chegamos a quase $50 \%$ do valor de referência da propriedade" (LOURENÇO, 2010, p. 137). Tal fato demonstra que a fazenda possuía como principal produção o aguardente, preferência no mercado de escravos africanos, e que ela estava preparada para o recebimento dos escravizados recém-chegados do continente africano. Enfim, ao longo da segunda metade do século XIX, com a proibição do tráfico em 1850, aliada ao fato de que a fazenda Santa Rita do Bracuí havia se especializado em tal comércio, a região entrou em declínio. Somou-se a isso, o crescimento da produção de café no Vale do Paraíba, na qual os Breves passaram a conduzir toda a sua força produtiva e econômica. Esse abandono se deu de forma gradual, à medida que o tráfico ia se tornando inexequível.

Uma tentativa de desmoralização da lei de 1850 foi realizada juridicamente pelos comendadores. Diante do insucesso desse feito, os mesmos optaram, até quando foi possível, pela clandestinidade do comércio. Com grande influência no meio político, José Breves, talvez por isso, não tenha sido tão 
associado, assim como seu irmão o foi, ao tráfico transatlântico. Cabe lembrar que em 1853 foi direcionada, por Breves, uma carta a Euzébio de Queiroz, na qual havia a tentativa de desfazer qualquer relação com o episódio do Brique Camargo em suas terras. Na ocasião, Eusébio de Queiroz afirma que as visitas do conhecido traficante Coimbra à fazenda Santa Rita do Bracuí, realizadas antes do episódio do Brique Camargo, não são suficientes para associar o tráfico de africanos a José Breves, mostrando-se assim bastante inclinado a apoiá-lo. Ofícios chegaram a ser omitidos por ele, em 1853, ao ex-ministro e amigo pedindo o fim das buscas da polícia em fazendas de sua propriedade e também nas de seus pares:

me dirijo a V.Exa. a pedir-lhe por eles, e por mim, sua valiosa proteção vista do estado a que se podem ser levados nossas fazendas (...) vesse essa classe importante [os lavradores] exposta a um domicílio militar, destacamentos invadindo suas propriedades para procurarem africanos boçais: vesse essa classe sujeita a interrogatórios e aos caprichos de uma ou outra tensão (...) a continuar a porem em muito risco nossa segurança, abalará nossas fortunas, e pode acarretar para o país, funestas consequências.” (LOURENÇO, 2010, p. 155).

A preocupação de José Breves se deve ao fato de que as investidas da polícia poderiam levar à certeza de ser ele, Breves, traficante e de estarem dispondo, ele e seus pares, de um grande número de escravizados ilegais nos primeiros anos após 1850 mediante a entrada de um grande número de "pretos novos" em suas fazendas. Além disso, a presença da polícia poderia provocar nos escravos a perspectiva de denunciarem seus fazendeiros e conseguirem a tão desejada liberdade. Após a lei de 1831, aproximadamente meio milhão de escravos havia chegado ao Brasil, o que os tornava, judicialmente livres. Soma-se, ainda, o fato de que uma averiguação da polícia nas fazendas poderia pôr em risco todo o investimento clandestino realizado, uma vez que muitos escravos chegados ao Brasil após 1850 haviam aprendido o português. Esses elementos causavam grande temor nas elites do período.

Os Breves ainda foram acusados, após o caso do Brique Camargo, de outros desembarques na região de Marambaia e Bracuí. O Brique Maria Izabel, de Joaquim Breves, foi suspeito de traficar negros escravizados para o litoral Sul do Rio de Janeiro, em 1853. Além disso, em 1855, tiveram seus nomes associados ao traficante de escravos Francisco Ruviroza. Em outra situação, o Vapor Thetis que patrulhava a região Sul Fluminense afirma, em seus relatórios, o envolvimento de José Breves com o tráfico de escravos. (LOURENÇO, 2010). 
Sem êxito no âmbito legislativo, os irmãos Souza Breves não hesitaram em burlar a lei, mesmo quando o Estado Imperial decidiu deixar de permanecer conivente com o tráfico, em 1850, com a lei Euzébio de Queiroz. Os Comendadores participaram ativamente do comércio de africanos desde a sua primeira proibição, no início da década de 1830, até mesmo depois de 1850. As fazendas dos irmãos Breves, no litoral sul fluminense, dentre elas a do Bracuí, ficaram conhecidas, em diversos documentos do período, como palco dos últimos desembarques de africanos ocorridos na ilegalidade no Império do Brasil. (MATTOS, ABREU, SOUZA E COUTO, 2009, p. 13)

Diante de todo o exposto, é possível concluir que era muito rentável o comércio ilegal de escravizados sob o qual os Breves haviam construído um grande esquema de tráfico: tinham agentes no continente africano; possuíam embarcações próprias para o comércio negreiro; possuíam estrutura para o desembarque e recepção dos escravos em suas fazendas, como na fazenda Santa Rita do Bracuí e Marambaia; e organizavam a distribuição e venda para suas fazendas e de outros fazendeiros. Portanto, mesmo sendo judicialmente e moralmente ilegal para boa parte da sociedade oitocentista, parece que os irmãos Breves não tinham nenhuma pretensão em pôr um fim a tal empreendimento comercial. A fazenda Santa Rita do Bracuí, provavelmente, deixou de ser interessante economicamente após a lei de 1850, uma vez que funcionava em função do tráfico de escravizados.

Já no final do século XIX, mais especificamente no ano de 1877, o Comendador José Joaquim de Souza Breves escreve um testamento no qual doa parte das terras da antiga fazenda de Santa Rita do Bracuí para os seus antigos moradores, formados na sua maioria por escravos e libertos. O testamento também concede alforria aos ainda escravizados, junto com uma parte da terra. Cabe explicitar que o testamento foi escrito em um período de declínio econômico da Fazenda de Santa Rita do Bracuí. Esse testamento foi aberto em 1879, após o falecimento do comendador. Segue um trecho do testamento:

Declaro que a Fazenda de Santa Rita do Bracuí na Comarca de Angra dos Reis, 'tenho conservado de propósito para dela fazer uma aplicação caridosa e com inteira satisfação para a expor o que desejo. Atendendo eu ao lastimável estado de penúria que se observa naquele lugar, deixo em benefício das pessoas ali residentes, e que são meus agregados gratuitos e todos morigerados, para não ficarem privados dos meios de subsistência. (MATTOS, ABREU, SOUZA E COUTO, 2009, p.32). 
Contudo, esse testamento não foi entregue diretamente às famílias libertas da fazenda Santa Rita do Bracuí, o que abriu precedentes para sucessivas investidas de grileiros e posseiros. A articulação dos registros históricos do passado com as tradições orais e memórias dos descendentes de escravos nos permite repensar a história dos últimos anos da escravidão e do tráfico negreiro internacional. Mesmo em meio às diversas ameaças de expulsão desde o século XIX, a memória passada dos mais velhos para os mais jovens possibilitou uma identidade de pertencimento, de valor e de incentivo para permanecerem no Bracuí:

No Bracuí, memória e história aproximam-se para acertar as contas com o passado. Um passado marcado pelo tráfico de escravos, pela escravidão e pela luta pela terra, que até então não havia alcançado a historiografia, nem os livros didáticos; um processo que havia sido sepultado pela história, embora nunca tenha morrido na tradição oral de seus protagonistas negros e descendentes de escravos. (MATTOS, ABREU, SOUZA E COUTO, 2009, p. 7).

Cabe explicitar que a abolição da escravidão não foi seguida de políticas de inclusão social do negro ou de reparação da violência física e social sofrida. Assim como a maioria dos negros, os negros da comunidade de Santa Rita do Bracuí não sabiam ler. As memórias contadas sobre a doação das terras, portanto, serviu como estratégia de difundir esse passado e assegurar o direito sobre a propriedade da terra e herança recebida. Sobretudo, por ser no passado uma população não letrada cuja tradição oral era de extrema importância para sobreviver no presente, em diversos conflitos, esse passado foi recordado visando à garantia de direitos frente aos invasores de suas terras.

As relações sociais estabelecidas entre os moradores da fazenda de Santa Rita do Bracuí nos permitem pensar, mais uma vez, que tal doação de terras se deu não por bondade do fazendeiro, mas por ter sido uma conquista dos que ali viviam, visto que os moradores nos momentos que antecedem a doação de terras, já gozavam de certa liberdade de produção de gêneros para a subsistência e para o pequeno comércio local. Se por um lado, José Breves pode ter doado as terras na intenção das famílias continuarem a residir e a retirar seu sustento delas, por outro lado, pode ter sido motivado pelo desejo de manter sob controle seus subordinados em uma possível abolição da escravidão no Brasil, assim como fizeram outros fazendeiros. Nessa perspectiva é que podemos entender, ainda que com ressalvas, essa doação como uma conquista negociada no dia-a-dia, de 
maneira direta ou indireta, pelos moradores da comunidade. Distinto de outras comunidades quilombolas, essa doação tem um elemento peculiar, uma vez que foi registrada em testamento e não realizada em palavras, como na maioria dos casos. Em comum com outras comunidades, contudo, está o fato de que a posse da terra não foi regularizada.

A fazenda, por ter sido um local de desembarque de escravos, acabou contribuindo para um processo de realimentação da cultura de origem africana, uma vez que nela eram renovados os elementos de resistência cultural. Moradores da fazenda continuaram trabalhando em suas lavouras e em tarefas comunitárias. O reparo das máquinas ficava por conta de um homem que morava fora da fazenda e que recebia produtos como forma de pagamento por seus serviços. Esses equipamentos eram utilizados por todos os moradores da comunidade.

Não houve, imediatamente, grandes mudanças na organização da vida na fazenda logo após a doação das terras. Seus ocupantes permaneceram, basicamente, com a mesma ordem econômica e social. Resultado de negociação, resistência e luta, as conquistas dos escravizados e trabalhadores da fazenda do Bracuí se prolongaram e são compartilhados até os dias atuais. As relações sociais foram fortalecidas para que a vida comunitária se perpetuasse. Nesse histórico de existência, a comunidade do Quilombo de Santa Rita do Bracuí acaba por tornar a tradição oral "patrimônio cultural e base identitária do próprio grupo, definindo sua presença na região e o direito à terra de todos que partilham das narrativas e heranças culturais e materiais recebidas." (MATTOS, ABREU, SOUZA E COUTO, 2009, p. 8).

Os moradores quilombolas têm um grande respeito pelas tradições e formas de se viver dos "mais velhos" (expressão que usam ao se referirem aos seus antepassados e aos de idade maior da comunidade). Maneira de pensar distinta da sociedade contemporânea, na qual idosos são compreendidos como atrasados ou ultrapassados, sem nenhuma contribuição para os jovens. Sua função assemelha-se a dos Griots na África, que são contadores de histórias, cuja memória e a oralidade são suas principais ferramentas. Nas comunidades quilombolas os mais velhos ocupam papel central, pois seus conhecimentos são de extrema importância para o funcionamento do grupo. São considerados guardiões da tradição, como o uso coletivo do território e suas práticas culturais, como por exemplo, o Jongo. 
A comunidade Quilombola de Santa do Bracuí vivencia direta ou indiretamente esse passado, por isso suas identidades se relacionam com o passado da escravidão, em especial do tráfico ilegal de seres humanos do continente africano para o Brasil, uma vez que narram histórias aos mais jovens sobre o passado escravo, sobre o tráfico ilegal e outras tantas experiências vividas em comunidade. A oralidade ocupa papel central nesse processo, por meio dela, conseguem manter vivas suas trajetórias individuais e coletivas. Em suas narrativas contam histórias que reforçam seu pertencimento coletivo como agentes ativos e transformadores que conseguiram resistir, não deixando ser apagado esse momento tão sombrio da história da humanidade e, ao mesmo tempo, se identificam como guardiões desse passado, guerreiros que, como seus antepassados, precisam manter esta tradição na tentativa de construir um presente e futuro de igualdade.

Desde sua doação, a posse das terras quilombolas de Santa Rita do Bracuí, passou por lutas constantes contra expropriações. Podemos citar como exemplo desses processos, a ação de grileiros e a construção da BR101. Sendo essa última motivada pelo crescimento das áreas adjacentes e a especulação imobiliária. Os processos de expropriação de terras quilombolas estiveram, em várias ocasiões, associados ao "desenvolvimento" orientado por perspectiva de "progresso" construído sem se levar em consideração os interesses desses grupos e até colocando em risco a sobrevivência dos mesmos, ideia que balizou a opressão sobre as sociedades tradicionais, principalmente, as negras.

\subsection{As disputas pela terra: A sobrevivência do território.}

Neste capítulo, pretendo discorrer acerca de alguns conflitos nas terras doadas à comunidade Quilombola do Bracuí. Um dos primeiros conflitos que se tem conhecimento foi com Honório de Souza Lima, procurador oficial da fazenda Santa Rita do Bracuí, que em uma de suas visitas à fazenda, retirou as máquinas do engenho de cana e do monjolo com a desculpa de que seriam trocadas por novos equipamentos, o que nunca aconteceu. O mesmo Honório Lima, por volta de 1921, cadastrou a fazenda em seu nome tendo em mãos uma procuração que lhe permitia representar os moradores da antiga fazenda Santa Rita do Bracuí. Se valendo do fato de que os moradores da comunidade não sabiam ler, Honório 
produziu um documento de compra e venda e informou aos proprietários que se tratava da legalização de suas posses.

Segundo antigos moradores como seu Manuel Moraes, Totonho Seixas e José Adriano, nesta mesma época os moradores de Santa Rita assinaram documentos reconhecendo a venda das terras para Honório Lima, sem, no entanto, tomarem ciência do real conteúdo da documentação por pensarem que estavam assinando a legalização de suas posses. Portanto, inaugura-se um drama social que passa a ser tecido sem que os atores interessados tenham consciência de tais implicações. Em torno de 1921, Honório Lima cadastra as terras da fazenda em seu nome ao pagar os impostos na coletoria de Angra dos Reis. Muitos anos depois, em 1956, seus filhos demarcam os lotes de terra, mas não fazem qualquer tentativa de expulsão dos moradores legatários dos Breves que se mantêm alheios à situação dos tramites da documentação. (MATTOS, ABREU, SOUZA E COUTO, 2009, p. 57).

Outro relato bastante presente na memória de alguns moradores ocorreu em 1956 quando Maurício Pires, fazendeiro vizinho, na tentativa de forçar os moradores a pagarem $30 \%$ da produção das mesmas terras, avançou sobre as terras quilombolas afirmando serem de sua propriedade. As terras da fazenda vizinha, antes de Maurício Pires, haviam pertencido a José de Macedo que as perdeu por conta de dívidas com um Banco. A comunidade de Santa Rita do Bracuí passou a não trabalhar e não vender seus produtos a Maurício Pires. Nessa luta, cabe destacar o papel preponderante das mulheres que com facas e pedras passaram a ameaçar o fazendeiro caso ele não deixasse as terras da comunidade (BRAGATTO, 2000):

Depois que o Macedo morreu, a fazenda ficou com o banco. Foi nessa época, do tal banco que apareceu por aqui este tal de Maurício Pires pra tomar conta da fazenda, mas nós pensávamos que ele era dono. Depois, nós ficamos sabendo que foi um deputado lá de Angra que colocou esse sujeito aqui. (Manoel Moraes; março de 2009. In: MATTOS, ABREU, SOUZA E COUTO, 2009, p. 58).

Ainda segundo Mattos, Abreu e Couto (2009), na década de 1960, muitos moradores se associaram a Sociedade Civil de Proteção aos Lavradores, criada em 1951, com sede em Nova Iguaçu. A sociedade era, no período, presidida por José Correia. Os moradores foram seduzidos pelas promessas do presidente da instituição de regularizarem suas terras. Os camponeses deveriam pagar uma taxa e a cada 10 alqueires de terra regulamentados, os trabalhadores passariam três alqueires para a associação. Somente após dois anos de contribuição, os moradores descobriram se tratar de uma farsa de José Correia, tendo em vista que suas terras permaneciam sem a devida regularização. Por esse motivo, se 
desligaram da sociedade de lavradores, contrataram um advogado de Paraty para anular os acordos com José Correia e o expulsaram. José Correia ainda conseguiu vender alguns lotes para algumas famílias, porém, nem todos ficaram em função das dificuldades de acesso ao local e à resistência dos locais em aceitar os novos moradores trazidos por José Correia:

\begin{abstract}
Nós nunca fomos de muita briga mas esse tal de Zé Correia a gente teve que dar um jeito nele... quem garrou e fez isso foi seu Antonio Seixas, pai do Totonho Seixas. Depois desse homem muito enganar a gente, seu Antonio ajuntou um povo aqui e fomos todos esperar ele lá no porto do Demarães. Ele vinha que vinha, crente que ainda era gente pra nós aqui... chegou, quando foi saltar da lancha, seu Antonio falou pra ele não pisar o pé na praia e nós num deixamos não.Tinha gente esperando com pau, pedra e cacete, todo mundo doido pra dar uma coça nele...Foi indo ele viu que o caldo tinha engrossado e desistiu de saltar da lancha. Foi embora e não pisou mais aqui... Num voltou mas deixou as coisas complicadas pra nós! Tivemos que chamar advogado lá de Parati pra desembaralhar o rolo dele, porque de dez alqueires de cada associado, 3 era para ficar pra ele. Tinha um punhado de associado, então teve que desfazer o rolo todo né. Mas graças a Deus esse daí a gente se viu livre pra sempre! Dele e da confusão dele. (Manoel Moraes: março de 2006. In: MATTOS, ABREU, SOUZA E COUTO, 2009, p.59-60).
\end{abstract}

Tal episódio possibilita pensar como foi importante a manutenção da identidade comunitária na superação de barreiras que seriam impossíveis de serem ultrapassadas dentro de uma lógica individual capitalista, na qual a maioria dos indivíduos, a não ser que seu interesse pessoal seja ameaçado, não se atenta para o interesse coletivo.

Com o golpe de 1964, a crescente repressão da ditadura brasileira significou um retrocesso nos movimentos camponeses que vinham se organizando por reforma agrária e por melhores condições de trabalho. Criminalizando os movimentos sindicais, proibindo qualquer organização de se estabelecer sem o seu consentimento a Ditadura resultou em prisões, mortes e torturas das lideranças e de membros destas organizações. Mesmo nessa conjuntura, os moradores do Bracuí mantiveram sua organização comunitária, embora não institucionalizada, conseguindo resistir à política de fragmentação dos movimentos sociais instituída pelo governo autoritário.

Em 1967 ocorreu outro momento marcante na memória dos moradores relacionado ao conflito das terras. Dessa vez foi com um membro da própria comunidade, o senhor Antônio Azevedo, conhecido na comunidade como Âmbar. Responsável por apresentar o senhor José Correia à comunidade, Âmbar gozava 
de certo respeito por o considerarem um homem com conhecimento e dono de um armazém no qual todos compravam e dependiam. O Sr. Azevedo entrou com uma ação de usucapião para regulamentar 30 alqueires que dizia ocupar por mais de 40 anos, um lote muito maior do que aquele pertencente a ele. Nessas terras, habitavam 20 famílias remanescentes da antiga fazenda do Bracuí. Ou seja, tentou se apropriar de parte das terras da comunidade sem se preocupar com as famílias que ficariam sem seu meio de sustento. A família do senhor Francisco Passos foi uma das enganadas, porém, este foi até a justiça e conseguiu recuperar suas terras. (MATTOS, ABREU, SOUZA E COUTO, 2009).

Via título de propriedade, o Estado deveria legitimar e garantir o direito dos camponeses sobre as terras, assim como meios para que retirassem delas seu sustento. Todavia, não se ocupando dessas demandas, o governo militar colaborou no sentido oposto. Desarticulando o movimento de construção de uma organização de lavradores e, neste engano de progresso, acelerando, por meio da indústria do turismo, o avanço sobre Angra dos Reis. Processo no qual os camponeses ficaram descobertos perante tamanha pressão dos agentes invasores respaldados pelo próprio Estado. Mais uma vez, assim como nas primeiras décadas após a doação das terras, depois de longos anos de conflitos, os moradores se encontraram totalmente desamparados.

A construção da BR 101, ligando a cidade do Rio de Janeiro à cidade de Santos, em 1972, se constituiu como outro duro golpe desferido pelo Estado contra os camponeses. Também conhecida como Rio-Santos, a construção dessa rodovia pelo Estado não levou em conta o impacto dessa ação sobre a vida das pessoas que tiveram suas terras cortadas por uma rodovia, tampouco houve a realização de uma consulta aos moradores com a intenção de se pensar suas demandas socioeconômicas e, nesse sentido, caracterizou um corte não apenas sobre as terras quilombolas, mas, sobretudo, sobre a vida social e cultural das famílias quilombolas. Uma agressão até os dias de hoje ainda não cicatrizada. Um passeio ao longo da rodovia Rio-Santos deixa a impressão de que houve um projeto orquestrado pelo governo para reservar o lado próximo ao mar à especulação imobiliária. As belezas da Costa Verde são desvendadas para o mundo com a criação desta rodovia, agravando o processo de lutas e, com o passar dos anos, desarticulando o movimento camponês. Houve um processo maior de fragmentação do território tradicional por causa do processo acelerado 
de especulação das terras com o advento da rodovia. $\mathrm{O}$ crescimento da vida urbana seduziu muitos moradores do quilombo que venderam, por valores baixos, parcialmente ou totalmente, suas terras para poderem sobreviver e buscaram o sonho de uma vida melhor em um emprego urbano. Famílias passaram a buscar empregos em condomínios, no comércio e em atividades ligadas ao turismo.

O início da construção da Usina Nuclear, no ano de 1972, e sua posterior inauguração, no ano de 1985, corroboraram a expropriação das terras quilombolas. A exposição de Angra dos Reis devido a essas duas grandes obras mudou drasticamente a fisionomia do município, uma vez que operários de outras cidades que foram trabalhar na construção da Rio-Santos e da Usina Nuclear, passaram a morar em Angra dos Reis por meio da ocupação irregular e pela compra de pequenos lotes de terra. Alguns desses terrenos se encontravam na comunidade quilombola Santa Rita do Bracuí. Pescadores e homens pobres perderam suas casas e viram-se obrigados a se mudarem para favelas no Centro de Angra. Na mesma medida, áreas ambientais, como as praias e mangues, começaram a ser ocupadas por casas, resorts, condomínios de luxo e marinas. Os peixes também desapareceram à medida que rios e mares foram contaminados pelo esgoto oriundo do crescimento urbano desordenado. Legitimada pela EMBRATUR (Empresa Brasileira de Turismo), órgão governamental que apoiava e incentivava projetos turísticos na cidade, a especulação imobiliária foi se estabelecendo. Os moradores do Quilombo do Bracuí não conseguiram escapar dessa onda devastadora, resultado do projeto desenvolvimentista que não levou em conta o cotidiano dos moradores de Angra, principalmente dos mais pobres, que tiveram suas vidas alteradas drasticamente, passando a sofrer um processo de alijamento da vida ligada ao cultivo, cuja propriedade era de uso comunal.

Em 1973, a família de Honório Lima vende as terras fraudadas do território quilombola para Lydia dos Santos, que as repassa para a Casa Construtora e Administração S.A. Em 1975, a Empresa Bracuhy Administração Empreendimentos em Participações Ltda, propriedade de Renato Xavier, as compra com o objetivo de realizar investimentos de condomínios de luxo, chácaras e estruturas turísticas às margens do mar. Em 1978, Xavier também comprou as terras de Antônio Azevedo o que o fez cada vez mais avançar sobre as terras quilombolas. Como forma de inibir questionamentos, a empresa agiu rapidamente na direção de frear qualquer movimento de contestação dos 
camponeses e assegurar o direito sobre as terras compradas. Primeiramente, utilizando-se da violência, e, concomitantemente, em 1981, acionando a justiça local, que emitiu um parecer favorável à empresa. Os moradores, quando tentaram garantir a posse definitiva das terras na justiça, não conseguiram. Em contrapartida, a empresa conseguiu a regularização sem muitos esforços, expressando o caráter elitista da nossa justiça e o descaso com as demandas dos nossos camponeses. O trecho abaixo destaca a violência empregada pela empresa contra os moradores do quilombo:

As tentativas de expulsão foram diversas e conhecidas, entre elas: intimidação aos moradores, inclusive com homens armados andando pelas terras da fazenda; cercas de arames farpados, separando a plantação e mesmo impedindo que se continuasse a cuidar do plantio; implantação de várias barragens ao longo do rio Bracuhy, que impedia os moradores de terem água corrente em suas casas, além de várias investidas junto aos moradores mais influentes, para que vendessem suas posses. (BRAGATTO, 2000, p. 121)

Como outros ocorridos no Brasil, o conflito descrito acima ficou marcado pela ausência de agentes do Estado no impedimento do poder econômico de se sobrepor ao pequeno camponês. Portanto, de certa forma, o Estado se comportou como um parceiro à prática ilegal. Especialmente, por legitimar as agressões ao não averiguar devidamente as proposições colocadas pelos atores envolvidos no processo. Desse modo, mais uma vez, essas populações, muitas expulsas das terras invadidas ou compradas ilegalmente por baixos valores, só puderam contar com a solidariedade de seus pares pedindo abrigo nas terras de seus companheiros que não se encontravam na faixa de terra em disputa. Sem a preocupação de preservar o meio ambiente e as antigas formas tradicionais de vida dos caiçaras, indígenas e camponeses, o dito progresso chegava à região. As antigas formas de vida foram sendo engolidas por essa onda do "progresso". De um dia para o outro, esses grupos se encontraram sem suas terras, suas casas, seu sustento e descamisados dos seus espaços de construção sociocultural.

A chegada dos novos projetos, como o de Furnas, é considerada por alguns como importante, quando julgada a possibilidade da chegada de energia elétrica. Ao mesmo tempo, a abertura de novas vias facilitou o escoamento de produções agrícolas. No entanto, essas ditas benfeitorias acarretaram estragos que jamais serão reparados. Grupos se viram obrigados a venderem ou abandonarem suas terras, tendo que buscar formas de sobrevivência que lhes afastaram, aos 
poucos, das formas tradicionais de convivência e produção. Soma-se a isso a chegada, em busca de trabalho, de novos grupos a Angra, o que generalizou os conflitos pela terra.

Diante de todos os acontecimentos, os moradores da comunidade quilombola, mesmo com todas as ameaças e retaliações sofridas, não se acovardaram diante deste novo invasor. Ao contrário, ainda na década de 1970, buscaram o apoio da Comissão da Pastoral da Terra (CPT) por intermédio do Frei Jorge, que na época atuava na região e reuniram-se para lutar por suas posses. A presença da CPT possibilitou certa proteção, orientação e um maior espaço de visibilidade perante a sociedade e autoridades. $\mathrm{O}$ depoimento de antigas lideranças acerca da importância da atuação da Pastoral da Terra e de Frei Jorge, reafirma essa parceria e atuação:

Acompanhei muito Pastoral da Terra. Frei Jorge era muito bom, na sabedoria dele ensinou muito pra nós. Defendeu muito nós. Falava que nós somos donos da terra porque a terra é toda de um dono só que é Deus. Ele deu a terra pra nós plantar, ele é que é o dono de tudo... Foi muito bom porque era uma gente de ciência muito grande. Fizeram a gente ficar atento nas escrituras, porque nem sempre quem diz que é dono da terra é de verdade. Então explicavam pra gente o que tava na escritura e que era nosso. (Dona Joana: março de 2009. IN: MATTOS, ABREU, SOUZA E COUTO, 2009, p. 67).

No ano de 1978, mediado pela Pastoral e pelo pároco, os moradores da comunidade entraram com uma ação na justiça com o advogado Edival Passos (assessor da Federação dos Trabalhadores da Agricultura do Rio de Janeiro), reivindicando as terras tomadas pela empresa Bracuhy Administração Empreendimentos em Participações Ltda e o restabelecimento das divisões e demarcações originais da antiga Fazenda Santa Rita do Bracuí. O argumento de defesa partia do pressuposto de uma posse imemorial.

A proposição, contudo, esbarrou na falta de provas sobre a afirmação de que os moradores das terras fossem herdeiros de Breves. Neste período não havia mecanismo jurídico que estabelecesse o direito coletivo sobre as terras. O advogado da empresa apresentou uma escritura com 320 alqueires comprados dos herdeiros do testamenteiro (Honório Lima) do comendador Breves. Cabe lembrar que estas terras foram registradas de maneira ilegal no início do século XX. No caso do Bracuí, mesmo ocupando o território por mais de 70 anos, aos moradores não foi permitida nenhuma justificativa de usucapião na obtenção do direito sobre as terras. Na medida em que o "proprietário" estava reclamando a posse das terras 
na justiça, os mesmos não poderiam usar desta possibilidade. As ações movidas pelos camponeses no Brasil, ao longo das décadas de 1960 e 1970, conseguiram, no máximo, prolongar por um período a ocupação das terras. Quando os moradores do Bracuí perdiam ações na justiça, a violência se tornava maior e os mesmos corriam sérios riscos de despejo.

$\mathrm{O}$ advogado dos moradores do quilombo buscou provar a herança das terras por meio do testamento. $\mathrm{O}$ documento que comprovava a doação de terras aos moradores do Quilombo Santa Rita do Bracuí, foi encontrado nos registros da cidade de Barra do Piraí. Esse documento foi entregue ao juiz responsável que autorizou a permanência das famílias no local. O testamento foi aceito como prova da posse, contudo, não se conseguiu provar a ancestralidade desses com aqueles que ganharam as terras de Breves. Os moradores e o advogado começaram a buscar registros em paróquias de cidades vizinhas, visto que em Angra dos Reis não havia cartórios de registros no ano de 1879. Na cidade de Barra Mansa foram encontrados registros de batismos e de casamentos, alguns também foram encontrados no Convento do Carmo em Angra dos Reis. Com essas descobertas, os moradores começaram a traçar paralelos entre os nomes dos atuais moradores e origens familiares. Assim, conseguiram comprovar suas teses e iniciaram uma discussão no sentido de estabelecer uma linha de defesa.

No entanto, esta ação não alterou a perda de grande parte das terras para a empresa citada anteriormente. $\mathrm{O}$ que não levou os moradores a desistirem de resistir e lutar pela posse da terra ao longo desses anos. Na sentença, de 1981, favorável à empresa Bracuí, já mencionada, argumenta-se que não foi provado "nem propriedade nem descendência" (MATTOS, ABREU, SOUZA E COUTO, 2009, p.68). Antes mesmo de uma sentença definitiva, a empresa já começa a fazer pressão para expulsar as 20 famílias que moravam nas terras que ficavam entre a Rio-Santos e o mar. A maioria dos moradores não suportou as ameaças e as pressões e acabou mudando-se para parte mais próxima das montanhas. Outros deixaram a região. Esse conflito se estende para o "sertão" (terras do Bracuí que ficam exprimidas entre as montanhas e a rodovia Rio-Santos), onde a empresa, em 1977, começou um processo de retirar pedras das margens do Rio Bracuí para utilizar na construção do condomínio Bracuí. Os moradores chegaram a fazer uma porteira para impedir, mas a justiça concedeu liminar autorizando a extração pela empresa Bracuí. Os moradores organizaram, ainda em 1981, um cordão humano 
como última alternativa para preservar o Rio Bracuí e, consequentemente, a sobrevivência material da comunidade que dependia do equilíbrio ambiental proporcionado pelo mesmo. Assim, "homens, mulheres e crianças, num total de 51 pessoas, formando um cordão humano, impediram a entrada das máquinas ficando de pé diante delas.” (MATTOS, ABREU, SOUZA E COUTO, 2009, p.70)

É fundamental ilustrar que o protagonismo dos moradores do quilombo do Bracuí também está associado ao contexto histórico do país do final dos anos 1970 e da década de 1980, período de abertura política, no qual surgem vários movimentos sociais imbuídos de uma vontade de mudança social. Muitos com uma relação bastante intensa com grupos de esquerda e de progressistas ligados àIgreja Católica. Tais movimentos, fugindo da política tradicional marcada por um vanguardismo das elites, tinham como objetivo tornar esses homens sujeitos e protagonistas de suas próprias histórias.

Podemos enfatizar o papel da Pastoral da Terra como agente importante na fomentação, entre os moradores quilombolas do Bracuí, de um sentimento maior de autonomia e identidade coletiva, passando essa última a ser compreendida como um elemento importante na luta contra a expropriação de suas terras. O CPT colaborou, portanto, para uma participação maior destes sujeitos no embate político, uma vez que os mesmos passaram a se perceber como principais responsáveis neste processo de luta por terras e melhores condições de vida. O estreitamento da relação entre comunidade e CPT tem como um dos seus marcos o ano de 1975 quando ocorreu, em Goiânia, a 1a Assembleia Nacional da Pastoral da Terra, da qual participaram alguns moradores do Bracuí, tendo o primeiro contato com o Estatuto da Terra. A apropriação do conhecimento formal acerca da regulamentação das terras do campo torna-se importante de ser ressaltada, uma vez que foi por meio dela que os moradores puderam estabelecer estratégias de como encaminhar as problemáticas do seu cotidiano e ainda dialogar com seus mediadores sem serem enganados por aproveitadores.

O CPT concedia apoio jurídico, religioso e dava visibilidade por conta das diversas relações da Igreja junto à sociedade. Se por um lado os trabalhadores gozavam do apoio da CPT, por outro a Prefeitura de Angra dos Reis, o Ministério da Agricultura e o judiciário tinham maior simpatia pela causa dos fazendeiros, empresários e grileiros. Outra dificuldade era de ordem religiosa. Grupos ligados 
a outras religiões, em especial a protestante, que eram críticos à presença do CPT. No entanto, conseguir manter o homem no campo ainda se colocava como o maior desafio, devido às grandes dificuldades, o fascínio das cidades e à ausência do Estado como parceiro. O texto abaixo, de 1976, elucida as preocupações do CPT em relação à luta pela terra:

\begin{abstract}
A defesa e a luta pela terra é um momento pastoral de emergência e extrema urgência. Pode envolver decisões à atividades imediatas, sem poder contar com o devido preparo de pessoas envolvidas. (...) Corre-se o risco, porém, desenvolver um trabalho unilateral e paternalista, sem que isso leve a atitudes maduras e conscientes nas pessoas envolvidas. (...) Sem uma visão mais ampla a Pastoral pode resultar, de um lado, num derrotismo (no caso quando não se consegue o objetivo imediato) e, de outro lado, num cobiço desenfreado de posse da terra (no caso de uma vitória). Assim o povo teria a oportunidade de descobrir que a terra é 'emprestada' ao homem, para que ele possa produzir para o bem de todos. (BRAGATTO, 1996, p. 154).
\end{abstract}

A prerrogativa de estabelecer uma consciência acerca do uso da terra para o bem de todos está em acordo com os laços de solidariedade e de uso comunal das terras da comunidade quilombola do Bracuí. Essa orientação do CPT foi importante, visto que orientou, concedeu suporte e, especialmente, ajudou a reforçar sua identidade coletiva. Percebendo que a terra os alimenta e merece ser cuidada, a comunidade a considera como uma mãe. Acrescenta-se o fato desta terra estar ligada à vida de seus ancestrais, como um espaço de sociabilidade daqueles que ali nasceram ou daqueles que vieram como escravos do continente africano. Foi dali que tiraram, totalmente ou parcialmente, sua sobrevivência, ali constituíram suas famílias, mantiveram suas tradições, sua memória, sua identidade.

Decerto, nem todos se mantiveram firmes na luta contra a expropriação de suas terras, contra diversos agentes e em diferentes momentos históricos. Alguns abandonaram suas terras ou as venderam por um preço abaixo do valor de mercado. Os que resistiram conseguriram fortalecer ainda mais essa identidade coletiva e uma maior consciência quanto à importância da terra. O Trabalho de MATTOS, ABREU, SOUZA E COUTO (2009) destaca que no início dos anos de 1990 já havia um grande contingente de invasores, sitiantes e especuladores no território da antiga fazenda de Santa Rita. Atualmente, há dentro do território quilombola do Bracuí pousadas, sítios, restaurantes e casas de veraneio. A maioria dessas propriedades foi adquirida por meio de invasões, compradas de invasores 
ou de antigas famílias de quilombolas que venderam por causa de dificuldades financeiras. Uma parte dessas construções foi feita às margens do rio, impedindo o acesso do restante dos moradores do bairro, desviando seu fluxo e poluindo-o. Tais fatos comprometem a existência da comunidade quilombola uma vez que o rio e a floresta são partes importantes do território, sendo, portanto, fundamentais para a sobrevivência física e material da mesma. Um desses sítios, recentemente, estava organizando festas, causando sérios transtornos aos moradores. As festas deixaram de acontecer após uma liderança acionar a justiça.

O movimento negro do quilombo de Santa Rita do Bracuí surge como um dos desdobramentos dessas inúmeras lutas da comunidade. Sua articulação teve início no final dos anos 1999 e se consolidou em 2005, quando fundaram a AQUISABRA (Associação Quilombola de Santa Rita do Bracuí). No Bracuí é ressaltado o papel de Délcio José Bernardo, militante do movimento negro de Angra dos Reis e membro do grupo Ylá-Dudu, no processo por identificação da comunidade enquanto quilombola e na valorização do jongo enquanto um patrimônio local a ser preservado, praticado e valorizado. Também cabe explicitar o papel do Quilombo do Campinho que ao adentrar na cena pública por suas demandas permitiu que jovens atores do Bracuí se percebessem como parte de uma comunidade quilombola. Isso ocorreu quando alguns membros da comunidade do Bracuí visitaram o Quilombo da Independência em 1999, descobrindo o significado de ser quilombola. Essa visita transformou a percepção da comunidade de Santa Rita do Bracuí, pois seus membros perceberam que boa parte do que caracterizava a comunidade do Campinho como quilombola também fazia parte da experiência da comunidade de Santa Rita do Bracuí. Os jovens retornaram com a convicção de que eram membros de uma comunidade quilombola, começaram a provocar a discussão na comunidade e aos poucos convenceram outros membros. Délcio Bernardo foi um parceiro importante, com sua experiência no movimento negro, na empreitada de ressignificar a identidade local.

A história dos quilombos não faz parte apenas de um setor da história da escravidão: ela é articuladamente, a própria história da pós-emancipação, história agrária, história do trabalho e dos movimentos sociais no Brasil. (GOMES, 2006, p. 307). 
Compreender a trajetória do Quilombo nos permite ter uma visão distinta daquela do discurso hegemônico e dos modelos sacralizados de produção e relações sociais. Nessa perspectiva, é possível caracterizar o quilombo do Bracuí como um espaço de resistência ao sistema social vigente, ao demonstrar sua capacidade de se articular com outros setores sociais e de modificar esse sistema. A história do Quilombo do Bracuí é a história de homens e mulheres que, resistindo a uma imposição social que os via como ultrapassados e um empecilho ao progresso, sem valorizá-los enquanto sujeitos capazes de contribuírem para esse progresso, procuraram se organizar em uma forma de comunidade e cultura.

Comunidades indígenas, Quilombolas, ribeirinhos e outras formas de comunidades tradicionais, além de campesinos e "sem terras"; todos esses exemplos possuem o sentimento que se perdeu na classe trabalhadora do interior das fábricas, esses "descontentes sociais" se veem como parte de um grupo que têm identidade própria e que tal identidade, dialeticamente se fortalece com a luta e respalda a mesma. É por estes casos que a questão da identidade ganha relevância nas lutas sociais. (BARATA, 2013, p. 38).

Comprendidos como entraves para o desenvolvimento da sociedade, como atrasados e ligados a um passado sem espaço no presente, esses grupos tradicionais - na luta para assegurarem seus modos de estarem no mundo - têm a identidade coletiva como combustível para assegurar seu modo de vida tradicional, especificamente, na garantia da regularização de suas terras. O sujeito da sociedade moderna tem sua identidade associada ao particular, e não ao coletivo. A identidade centrada no indivíduo e não no coletivo, tem dificultado a sociedade na organização e na luta por demandas que são do interesse de todos.

\section{3 "Quilombo, o que é isso?"}

Nessa parte, me proponho a discorrer acerca do processo de ressemantização do conceito de quilombo em diálogo com os diversos textos acadêmicos e os depoimentos de lideranças do próprio movimento quilombola. $\mathrm{O}$ conceito de quilombo passa por um processo de ressemantização ao longo da história do Brasil. Os trabalhos que li, até então, não tratam da temática partindo do eixo de como esses atores se apropriam do conceito no seu cotidiano e como ressignificam seu modo de vida, atribuindo novos valores individualmente ou coletivamente. Acentuadas disputas em torno do conceito ocorreram, principalmente, com o advento do movimento quilombola e ainda com a 
promulgação do Artigo 68 do Ato das Disposições Constitucionais Transitóriais (ADCT/CF), de 1988, que trata sobre os direitos territoriais das comunidades quilombolas, afirmando que: "Aos remanescentes das comunidades dos quilombos que estejam ocupando suas terras é reconhecida a propriedade definitiva, devendo o Estado emitir-lhes os títulos respectivos". ${ }^{8}$

A abordagem de tal proposição tem um caráter pedagógico na medida em que ainda há uma compreensão restrita do conceito de quilombo - o senso comum ainda associa quilombo apenas a acampamento de resistência armada, local para onde os escravizados fugiam e formavam comunidades guerreiras sem contato com as áreas urbanas ou subúrbios. Isso ocorre em função da presença tão forte dessa interpretação no imaginário social por meio de livros didáticos, reprodução cotidiana e outros canais de divulgação de informação. Alguns fazem essa apropriação por desconhecimento - como no caso de alguns professores que não querem a implementação de uma educação quilombola na unidade escolar onde trabalham e justificam com base nesse pressuposto - e outros desejam apenas negar o direito à terra ou a qualquer outro direito.

Se estes "remanescentes de quilombos" não são frutos da antiga forma e estrutura que tanto circunscreve o imaginário coletivo, como podemos defini-los? São comunidades formadas por um campesinato negro ou por seus descendentes, seja de colonos ou posseiros, que no pós-abolição não foram incorporados por uma política de reparação que possibilitasse uma inserção social e, por isso, lutam por suas demandas, como a garantia de direitos coletivos sobre a posse das terras.

Cabe ressaltar o trabalho de Arruti (2008) que nos possibilita conhecer algumas representações feitas por autores que se debruçaram sobre a temática dos quilombos no Brasil. Uma das primeiras abordagens foi de Nina Rodrigues, em 1905, que apresenta os quilombos como ligados à ideia de resistência cultural. Nina Rodrigues “caracterizou Palmares como uma forma de persistência da África no Brasil, um retorno à "barbárie africana"." (ARRUTI, 2008, p.5). Enfim, constrói uma narrativa negativando os elementos culturais que os quilombolas, pretensamente, queriam preservar.

Outras interpretações, nesse período, foram influenciadas pelo viés culturalista de Nina Rodrigues. Autores como Artur Ramos, Edison Carneiro e

\footnotetext{
${ }^{8}$ http://www.senado.leg.br/atividade/const/con1988/ADC1988 12.07.2016/art 68 .asp._Acesso em $29 / 06 / 2018$
} 
Roger Batiste partiram da concepção do quilombo como um meio de impedir a aculturação da cultura africana pela cultura do branco, em especial, o europeu. Uma visão um tanto essencialista das culturas dos negros no Brasil permeava essas análises. Além disso, os autores partem do pressuposto de que os quilombos adotam formas de organizações similares às desenvolvidas na África. Ou seja, seriam como uma resistência à segregação cultural oriunda da escravidão.

As pesquisas sobre rebeldia escrava crescem na década de 1950 junto com o movimento negro. Nesse mesmo período crescem as publicações de materiais que combatem a visão harmoniosa de Gilberto Freyre sobre as relações escravistas. No final da década de 1950 surgem estudos que tratam o quilombo como algo inserido dentro de uma luta de classes, isto é, partem de uma perspectiva materialista. Os quilombos seriam fruto de resistência, revoltas e insurreições. Seriam expressões revolucionárias que refletiam consciência, diferente das outras experiências de enfrentamento à escravidão, caracterizadas como de menor valor histórico por serem consideradas passivas. Essas narrativas também expõem a violência vivida pelos escravos na relação com seus senhores, desmitificando as narrativas paternalistas dessa relação: "Surgem, então, os trabalhos de Clóvis Moura e Décio Freitas, entre outros, nos quais os quilombos e revoltas escravas passam a figurar como assunto de destaque." (ARRUTI, 2008, p. 6).

Ao longo dos anos de 1970, o movimento negro ${ }^{9}$ milita na defesa de ter sido o quilombo o bastião da resistência negra. Com isso, passam a agrupar as interpretações culturais e políticas em disputa até então. Essa seria a terceira ressemantização do conceito de quilombo. Nesse período, o movimento negro reivindicava o 20 de novembro, dia da morte do líder Zumbi do Quilombo dos Palmares, como data alternativa ao 13 de maio e que a história do negro no Brasil fosse incluída nos livros didáticos e nas aulas durante o ano letivo das escolas. $\mathrm{O}$ 20 de novembro seria uma data que representaria a liberdade enquanto conquista de uma luta dos escravizados e libertos e não de um ato de generosidade da Princesa Isabel.

O livro "O Quilombismo" de Abdias Nascimento, publicado na década de 1980, converge com a abordagem do quilombo como movimento de resistência

\footnotetext{
9 Segundo Petrônio Domingues, o "Movimento negro é a luta dos negros na perspectiva de resolver seus problemas na sociedade abrangente, em particular os provenientes dos preconceitos e das discriminações raciais, que os marginalizam no mercado de trabalho, no sistema educacional, político, social e cultural." (p. 101, 2007).
} 
cultural e física da população negra. O movimento negro - no qual se inseria nomes importantes como o de Abdias Nascimento - propunha a revisão imediata da memória pública da escravidão e da abolição. (ARRUTI, 2008).

Na Constituição de 1988 emergem várias demandas sociais do movimento negro, dentre as quais a contrução de políticas de reparação em relação à escravidão. A titulação coletiva de terras de comunidades negras tradicionais, assim como o reconhecimento de patrimônio imaterial cultural das heranças afrodescendentes são partes destas conquistas. Como ressaltado anteriormente, o Artigo 68 do Ato das Disposições Constitucionais Transitórias da Contituição Brasileira de 1988 institui os direitos territoriais.

O Artigo 68 não pode ser entendido como uma benevolência das autoridades. Mas sua conquista se deve em parte aos movimentos negros da década de 1980, que lutaram por uma revisão da memória pública da escravidão e da abolição. A maioria das comunidades rurais negras que lutavam pela titulação de suas terras não se identificava com as formas clássicas do conceito de quilombo, abordadas até então, mas sim com o termo "terras de preto". (ABREU E MATTOS, 2011).

Em Julho de 1985, o Movimento Negro realizou o primeiro encontro estadual "O Negro e a Constituinte", junto à assembleia legislativa de Minas Gerais. Esses encontros se desdobraram, depois, para outros estados. Neles, todos visavam discutir a participação do negro na elaboração desta nova Constituição e chamar atenção para a problemática da exclusão do negro e do racismo incutido em todos os espaços sociais, seja de forma direta ou disfarçada:

\begin{abstract}
O processo social de afirmação étnica, referido aos chamados quilombolas, não se desencadeia necessariamente a partir da Constituição de 1988 uma vez que ela própria é resultante de intensas mobilizações, acirrados conflitos e lutas sociais que impuseram as denominadas terras de preto, mocambos, lugar de preto e outras disignações que consolidaram de certo modo diferentes modalidades de territorialização das comunidades remanescentes de quilombos. Neste sentido a Constituição consiste mais no resultado de um processo de conquistas de direitos e é sob este prisma que se pode assegurar que a Contituição de 1988 estabecece uma clivagem na história dos movimentos sociais, sobretudo daqueles baseados em fatores étnicos. (ALMEIDA, 2006, p. 33).
\end{abstract}

Como vimos ao longo deste capítulo, o Quilombo de Santa Rita do Bracuí tem um protagonismo na luta pela posse da terra, na sua organização social e nas suas práticas culturais. Almeida (2006) chama a atenção para um processo social 
de afirmação étnica que vai se desendadeando ao longo dos inúmeros embates sociais, de maneiras diferentes em diversos espaços de territorialização das comunidades quilombolas. Dessa forma, o Quilombo de Santa Rita do Bracuí, assim como demais quilombos, é responsável pela conquista do Artigo 68 que garante o direito coletivo sobre a terra:

A primeira articulação dessas comunidades se deu no Pará, em 1985, por meio dos Encontros de Raízes Negras. No Maranhão, a organização de informações sobre tais comunidades teve início em 1986, por iniciativa de militantes do Centro de Cultura Negra (CCN), que começavam a visitar os agrupamentos negros do interior do estado para articular o I Encontro das Comunidades Negras Rurais do Maranhão, já visando às discussões relativas à redação da nova Carta Constitucional Federal. (ARRUTI, 2008, p.11)

A participação do Movimento Negro também foi de extrema importância nesse contexto de discussão e elaboração da nova Contituição com um caráter mais social, uma vez que tentou influenciar por intermédio dos parlamentares e da opinião pública os trabalhos da Assembléia Nacional Constituinte de 1987. O racismo, a discriminação e várias formas de violência contra o negro foram temas das discussões que nortearam a Constituinte. A Carta Magna promulgada em 1988 estabelece a noção de direitos coletivos, nesse cenário se insere a questão das comunidades remanescentes de quilombos. A aprovação do Artigo 68 está dentro desse cenário da década de 1980 em que o Movimento Negro atuou veementemente por políticas de reparação para os negros, dentre as quais se encontra o direito a uma memória pública, à terra e a uma política de inclusão social.

O Artigo 68 abre, portanto, precedente para nova ressemantização do conceito de quilombo, não mais ligado a um acampamento militar de escravizados ou de libertos em busca de uma nova forma de organização social, mas a um território advindo de posse e/ou doação ocupado por comunidades rurais negras. Assim sendo, território de extrema importância na garantia de sobrevivência física e cultural das comunidades negras. A disputa em torno do conceito de quilombo está em curso na medida em que autoridades e outros agentes questionam o uso do conceito no sentido já exposto. $\mathrm{O}$ credenciamento como comunidade remanescente de quilombo pode gerar a titulação do território ocupado por esses grupos e o desdobramento em outras tantas políticas de inclusão social, como, por exemplo, uma educação quilombola. 
Nesse sentido, é importante o diálogo com as lideranças do movimento do Quilombo de Santa Rita do Bracuí na compreensão de como, individualmente e coletivamente, se apropriaram do Artigo 68 e ressignificaram suas identidades como uma dimensão importante na luta por direitos de reparação. Daí a importância da pergunta: o significa Quilombo para a comunidade e suas lideranças? Segundo a Liderança $\mathrm{B},{ }^{10} \mathrm{O}$ conceito de quilombo está associado ao conceito de território:

É um local. Quando fala de quilombo pra mim vem primeiro o pertencimento à terra, o território. O direito do negro a ter terra, daquela população negra, específica, descendente direta daquelas pessoas que foram trazidas pra cá como escravizados e que de certa forma criaram ligação com esse local, mantendo a cultura, a tradição, uma identidade africana de certa forma. Então, o quilombo é território.

A Liderança $\mathrm{A}^{11}$ segue a mesma linha ao afirmar que "quilombo é o território, é o espaço físico onde as pessoas moram, tem suas casas". O quilombo seria um território no qual populações negras, descendentes de escravizados, produzem e reproduzem relações culturais, econômicas e sociais. Sendo assim, o território personifica o conceito de quilombo contemporâneo. É o território que garante o direito de reparação, o modo de estar nesse território respalda o direito sobre a terra com base no Artigo 68. O direito à terra está atrelado a outros direitos, pois a sobrevivência do modo de viver e agir no mundo passa pelo território na medida em que é nele que se reproduzem:

a regularização das terras de quilombos não é uma questão prioritariamente cultural, já que o seu direito à terra e, por meio dela, à reprodução de sua diversidade enquanto grupos étnicos, não deriva do seu valor enquanto patrimônio cultural e sim dos direitos territoriais garantidos na constituição. A diversidade cultural passa a ser vista como subsidiária dos direitos territoriais, já que o suporte de sua identidade sócio-cultural é justamente o território. (ARRUTI, 2008, p. 12)

O quilombo contemporâneo, segundo a Liderança $C,{ }^{\mathbf{1 2}}$ seria um espaço de resistência: "Eu acho que quilombo é um espaço de resistência (...) espaço de resistência ao mesmo tempo é falar que ainda persisto, insisto e resisto à

\footnotetext{
${ }^{10} 32$ anos, cursando o curso de Educação no Campo na Universidade Federal Rural do Rio de Janeiro (UFRRJ), atual diretor de Educação da ARQUISABRA.

${ }^{11} 55$ anos, funcionária da Escola Áurea Pires da Gama, militante do movimento negro quilombola desde os 15 anos, atual coordenadora da ARQUISABRA.

${ }^{12} 32$ anos, com curso Normal em Nível Médio, atuou como professora no primeiro segmento do Ensino Fundamental em 2007, formada em Educação no Campo pela Universidade Federal Rural do Rio de Janeiro (UFRRJ) desde 2014.
} 
sociedade capitalista". É importante ressaltar que o conceito de quilombo permanece associado à ideia de resistência, não mais associado à luta pela liberdade do cativeiro, mas à resistência cultural, suas tradições, o direito à terra e à luta por políticas de reparação às populações negras, em especial, quilombolas. As sociedades tradicionais resistem à lógica perversa do capitalismo por valorizarem a propriedade comunal e as relações comunitárias, um contraponto à propriedade privada e às relações cada vez mais mercadológicas. O movimento quilombola se lança na luta por cidadania, há tempos negada a essas populações. $\mathrm{O}$ conceito de quilombo nos lança a pensar acerca do que significa ser quilombola. Para a Liderança E ser quilombola significa:

É você fazer parte desse contexto histórico, você ter consciência do que os seus antepassados passaram, da importância daquela terra, do território e das relações sociais que ali foram criadas. Ser quilombola é isso! É você entender o seu meio, não ser uma pessoa alienada nessa cultura eurocêntrica que tem aí, é se entender nessa identidade quilombola, de quilombo, nessa identidade onde o território está como carro chefe. Ser quilombola para mim é isso.

A Liderança B exprime quilombola como um indivíduo consciente da história dos seus antepassados, suas lutas pela sobrevivência física e cultural, se compreendendo como parte desse território. A Liderança A afirma que "são as pessoas que nasceram no território". A mesma nos possibilita compreender melhor quando diferencia um quilombola de um não quilombola: “A tradição, os costumes, os conhecimentos, a família, a descendência de negros que foram escravizados. Isto tudo se refere aos quilombolas”. Com base nessas informações, podemos pensar que quilombola é um sujeito dotado de uma trajetória marcada por um território onde se desenvolveu e se desenvolvem tradições, costumes e conhecimentos peculiares daquele grupo. É importante frisar que cada quilombo tem sua trajetória própria em termos históricos e culturais. Contudo, um dos elementos que os unem é a luta por políticas que garantam cidadania para os negros quilombolas.

Há um alargamento dos direitos de cidadania com a constituição de 1988, pois, até então, imperavam os direitos individuais. Esse reconhecimento cria atores, detentores de direitos culturais, sociais, coletivos e fundiários, que emergem da margem e pressionam na tentativa de ocuparem um papel ainda mais efetivo nas transformações sociais. O Artigo 68 foi imprescindível para futuras conquistas após a Constituição de 1988, dentre as quais podemos mencionar as 
cotas raciais e o reconhecimento das comunidades remanescentes de quilombo seja no âmbito cultural, étnico e da posse das suas terras. Esse artigo, assim como os novos marcos legais que surgiram posteriormente, tiveram grande "impacto na produção de novos atores políticos coletivos a partir da valorização da identidade negra e da memória de antepassados cativos.” (ABREU E MATTOS, 2011, p. $145)$.

A primeira titulação de terras só aconteceu em 1995, no Estado do Pará. ${ }^{13}$ Ao longo dos anos 90 ocorreu pressão, praticada pelo movimento quilombola, no sentido de garantir a regulamentação do Artigo 68 de maneira que reunisse o maior número de comunidades rurais negras. O Artigo 68 não caracteriza o que seria um comunidade remanescente de quilombo, abrindo margem para questionamentos jurídicos. O movimento quilombola pessionou, então, para que fosse regulamentada a lei de forma que prevalecesse a trajetória de resistência cultural e de luta pela terra das comunidades que pleiteiem a titulação. Sendo assim, podemos afirmar, mais uma vez, que há um processo de ressemantização da palavra quilombo. Um processo em aberto no tempo presente, na medida que é questionado por agentes conservadores e/ou agentes de áreas de conflito pelas terras:

Tendo em vista o crescimento do movimento quilombola a partir de final dos anos 1990, passaram a predominar, no campo antropológico e jurídico, as interpretações que consideravam a ressemantização da palavra quilombo para efeitos da aplicação da provisão constitucional, valorizando o contexto de resistência cultural que permitiu a viabilização histórica de tais comunidades (ABREU E MATTOS, 2011, p. 146).

A Constituição de 1988, em seus Artigos $215^{14}$ e $216,{ }^{15}$ assegura a proteção às culturas indígenas e afro-brasileiras. $O$ que caracteriza o estabelecimento do primeiro mecanismo constitucional que valoriza as contribuições dos negros para a sociedade brasileira e amplia a noção de direito, incluindo as práticas culturais. Desse modo, a Constituição de 1988 e o Artigo 68, configuram-se como mecanismos jurídicos que abriram precedentes para duas demandas do tempo presente: a primeira diz respeito ao direito sobre a terra tão

\footnotetext{
${ }^{13}$ Disponível em: http://www.cpisp.org.br/terras/ASP/tituladas.asp. Último acesso em 29/06/2018.

${ }^{14}$ https://www.senado.leg.br/atividade/const/con1988/con1988_15.12.2016/art_215 asp - visto em 23/11/2018.

${ }^{15}$ https://www.senado.leg.br/atividade/const/con1988/CON1988_05.10.1988/art_216_asp - Visto em 30/06/2018.
} 
cara para os camponeses negros que há muito tempo sofrem com o processo de grilagem e ação de posseiros e o segundo, diz respeito à luta por valorização de suas especificidades culturais. Portanto, tais mecanismos constitucionais fizeram com que diversas comunidades acionassem suas memórias e reivindicassem a identidade de remanescente de quilombola.

O Decreto abriu a possibilidade para o surgimento de novos canais de expressão cultural e luta política para grupos da sociedade civil. Antes silenciados, esses grupos são detentores de práticas culturais imateriais, avaliadas como tradicionais, o que tem sido fundamental para o processo de reconhecimento das comunidades remanescentes de quilombo (ABREU E MATTOS, 2011, p. 148).

Em 2000 é criado o Decreto 3.551 que assegura às manifestações culturais imateriais o status de Patrimônio Brasileiro. No seu "Art. $1^{\text {o }}$ Fica instituído o Registro de Bens Culturais de Natureza Imaterial que constituem patrimônio cultural brasileiro." ${ }^{16}$ Esse decreto foi fundamental para a luta do movimento quilombola que, com base em pressupostos culturais, também reivindicava a regulamentação do Artigo 68. O decreto $4.887^{17}$, de 2003, regulamenta o Artigo 68 , contribuindo para uma ampliação do sentido de comunidade de remanescentes de quilombolas, na medida em que possibilita a auto-atribuição:

Art. $2^{\circ}$ Consideram-se remanescentes das comunidades dos quilombos, para os fins deste Decreto, os grupos étnico-raciais, segundo critérios de auto-atribuição, com trajetória histórica própria, dotados de relações territoriais específicas, com presunção de ancestralidade negra relacionada com a resistência à opressão histórica sofrida. (BRASIL, 2003).

Cabe destacar que o decreto 4.887 propõe a titulação das terras de todas as comunidades que tenham sua história marcada por uma memória da escravidão e pela posse coletiva dessas terras, e não apenas dos remanescentes dos quilombos guerreiros. Além da origem étnica e posse da terra, a história dos conflitos enfrentados pela comunidade nesses processos também seria relevante para o uso do Artigo 68.

O reconhecimento da experiência da escravidão e da memória da África ou do tráfico como patrimônios culturais passou a validar as reivindicações das comunidades pela posse dos territórios ocupados coletivamente pelos mesmos. De

16 Disponível em: http://www.planalto.gov.br/ccivil_03/decreto/d3551.htm - Último acesso em 23/11/2018

${ }^{17}$ Disponível em: http://www.planalto.gov.br/ccivil_03/Decreto/2003/D4887.htm - Último acesso em $23 / 11 / 2018$. 
maneira geral, todos os sujeitos que residem nas terras dessas comunidades quilombolas são procedentes de um campesinato que surge no período da desagregação do escravismo no Brasil. Quando comparado ao período anterior àregulamentação do Art. 68, o reconhecimento da trajetória permite uma aceleração do processo de titulação e um aumento das comunidades que passam a reivindicar tal direito.

No ano de 2003 é fundada a AQUISABRA (Associação Quilombola de Santa Rita do Bracuí) com a intenção de estabelecer caminhos a serem percorridos pela comunidade, seja no tocante à sua organização interna ou no diálogo com as autoridades públicas para a certificação junto a Fundação Cultural Palmares (FCP) - responsável por identificar e conceder a certificação de comunidades quilombolas. Até 15 de dezembro de 2017 haviam 2.547comunidades certificadas pela FCP como remanescentes de quilombo, ${ }^{18}$ deste número, contudo, apenas 175 comunidades receberam o título de suas terras pelo INCRA. ${ }^{19}$

Cabe enfatizar que o crescimento do reconhecimento do número de comunidades quilombolas não foi acompanhado pelo aumento de terras tituladas. Esse procedimento esbarra, cotidianamente, na burucracia e na pressão do agronegócio, de grileiros e da especulação imobiliária. Em 1999, a comunidade de Santa Rita do Bracuí foi reconhecida como quilombola pela FCP. Entretanto, só foi certificada pela mesma no dia 24 de fevereiro de 2012 e, até o momento, não recebeu a titulação de suas terras. Uma busca na página eletrônica da Prefeitura de Angra dos Reis permite ter acesso à fala do presidente, à época, da AQUISABRA, Emerson Ramos, sobre a temática em questão "Esta certificação reforça toda a luta da comunidade, para a preservação de sua história e sua cultura, sendo um passo importante para conseguir a titulação das terras". ${ }^{20}$

Esse depoimento expressa a consciência dos agentes públicos em relação ao valor da comunidade quilombola como elemento importante da cultura brasileira e, ainda, como a comunidade se apropria disto para dialogar com o Estado, em especial com os Decretos 3.551 e 4.887, já citados acima. Esse conhecimento também está associado à presença de mediadores que se colocaram

\footnotetext{
${ }^{18}$ Disponível em: http://www.palmares.gov.br/file/2018/01/QUADRO-GERAL-29-01-2018.pdf Último acesso em 30/06/2018.

${ }^{19}$ Dado tirado de Quilombos e Legislação - Comissão Pró-Índio de São Paulo - Disponível em: http://www.cpisp.org.br/terras/asp/terras tabela.aspx - Último acesso em 30/06/2018.

${ }^{20}$ Disponível em: https://www.angra.rj.gov.br/noticia.asp?vid noticia=25241\&IndexSigla=imp. Último acesso em 30/06/2018.
} 
em defesa da causa quilombola e de pesquisadores de universidades cujo diálogo com a comunidade tem contribuído para a formação de novas lideranças, na produção de material sobre sua história e de maior visibilidade social.

\title{
Consideração finais:
}

Há uma dívida histórica com as populações negras que sofreram com o processo de escravização e com todas as suas mazelas, dentre as quais o racismo. Esse capítulo tentou cumprir o papel de demonstrar o protagonismo do Quilombo do Bracuí na luta por seu território e por políticas de reparação, ao lutar pela titulação de suas terras. A realidade social do Bracuí é apenas um microcosmo social da luta por terra e por cidadania de várias comunidades quilombolas e de tantas outras camponesas que sofrem com o processo de espoliação de suas terras por meio de posseiros e grileiros e o abandono das autoridades que ignoram suas demandas sociais básicas.

A história do Quilombo do Bracuí e de seus antepassados, antigos escravizados, chega ao tempo presente por meio da tradição oral. Essa mesma tradição possibilita a reconstrução de suas identidades como remanescentes de quilombo. Por meio da oralidade e de outros registros do passado é possível construir outra história sobre os últimos anos da escravidão e do pós-abolição, na qual esses atores aparecem como protagonistas na luta pelo direito a seus territórios e por políticas de reparação que garantam a plena cidadania.

\begin{abstract}
A tradição oral, transmitida através de muitos "causos" - como definem os moradores do Quilombo do Bracuí - constitui uma das mais importantes bases da identidade do grupo e de manutenção de seu território. Contar "causos" de antepassados escravos para os filhos, sobrinhos e netos foi, sem dúvida, uma estratégia dos mais velhos de uma comunidade não letrada para que o passado permanecesse no presente, para que não se esquecesse, especialmente, o direito à propriedade da terra e à herança recebida. (ABREU e MATTOS, 2011, p. 151).
\end{abstract}

Ao fazer uma breve análise do conceito de quilombo tentei mostrar a importância de desvendar os diferentes extratos de tempo e diferentes interpretações existentes. Há um campo de disputa narrativo que implica em relações de poder. Essas perspectivas contribuem para entendermos o processo histórico como mutável e, também, desnaturalizá-lo, uma vez que tais concepções estão associadas a experiências históricas que implicam na construção de memórias, de identidades e de direitos. 


\section{Capítulo II - Dimensão Pedagógica do Movimento Social}

De pronto, esclareço: para nós, a educação não se resume à educação escolar, realizada na escola propriamente dita. Há aprendizagens e produção de saberes em outros espaços, aqui denominados de educação não formal. Portanto, trabalha-se com uma concepção ampla de educação. Um dos exemplos de outros espaços educativos é a participação social em movimentos e ações coletivas, o que gera aprendizagens e saberes. Há um caráter educativo nas práticas que se desenrolam no ato de participar, tanto para os membros da sociedade civil, como para a sociedade mais geral, e também para os órgãos públicos envolvidos - quando há negociações, diálogos ou confrontos. (GOHN, 2011, p.333).

Esse capítulo tem como principal objetivo identificar os aprendizados e saberes do movimento negro, em especial, quilombola, partindo do pressuposto que esses grupos produzem conhecimentos importantes para a construção de um currículo escolar quilombola. Na sociedade contemporânea ainda é muito comum a ideia, equivocada, de que a educação é realizada apenas no espaço escolar. Os educadores são constantemente responsabilizados pelo dito "fracasso escolar" dos alunos, ou seja, na maioria das vezes o debate acerca da qualidade da educação só passa pela questão da formação dos professores. A educação não é discutida de forma ampla, e assim, cria-se uma cortina de fumaça para esconder os sérios problemas da educação pública no Brasil, na qual o professor é visto como o maior "vilão". Uma parte da sociedade acredita ser apenas a educação formal a responsável pelo processo de formação dos alunos, não compreendendo que a educação se estende para outros espaços e ainda, que a educação está para além dos muros da escola. O ser humano está em um processo contínuo de aprender, sua educação acontece na vivência cotidiana, nesse sentido, há outros espaços de formação além dos escolares a serem considerados, dentre os quais se encontram os movimentos sociais.

Além disso, a ausência de um debate acerca da dimensão da educação não formal tem prejudicado a construção de um sistema educacional que seja pensado de forma compartilhada, no qual todos os cidadãos sejam vistos, também, como responsáveis pela formação dos mais jovens, considerando que outros grupos e experiências sejam compartilhados e compreendidos como elementos chaves para a construção de uma educação de qualidade. Nessa perspectiva, a qualidade não está associada ao desempenho em avaliações padronizadas, mas à construção de 
cidadãos conscientes, solidários e críticos. Nesse sentido, esse trabalho tem por objetivo discutir como se edificam aprendizagens e saberes na militância política do movimento social, em especial, no movimento negro e quilombola. Dentre esses saberes e aprendizagens, cabe explicitar o papel que a memória social, coletiva e política desempenha nesse processo de construção de suas identidades enquanto movimento social e individual.

O estudo da relação entre educação e movimentos sociais ainda é relativamente recente. No final dos anos de 1970, esse estudo começa a ganhar espaço nas associações e entidades científicas que passaram a discutir o papel dos movimentos sociais no enfrentamento dos problemas socioeconômicos e políticos, ou seja, deram destaque aos agentes que vinham apontando os problemas e exigindo soluções para as mazelas sociais. Como exemplos mais atuantes, cito a Associação Nacional de Pós-Graduação e Pesquisa em Educação (ANPED), a Sociedade Brasileira de Sociologia (SBS) e as Conferências Brasileiras de Educação (CBEs). O trecho a seguir enfatiza o papel educativo do movimento social ao demonstrar como seus membros, por meio de ações coletivas, demandam do poder público políticas públicas:

A relação movimento social e educação foi construída a partir da atuação de novos atores que entravam em cena, sujeitos de novas ações coletivas, [...] demandando ao poder público o atendimento de suas necessidades para sobreviver no mundo urbano. Os movimentos tiveram papel educativo para os sujeitos que o compunham. (GOHN, 2011, p. 334)

Mas, afinal, o que são movimentos sociais? A autora Gohn afirma que são "ações sociais coletivas de caráter sócio-político e cultural que viabilizam formas distintas de a população se organizar e expressar suas demandas." (GOHN, 2011, p. 335) Nessa perspectiva, dentre as estratégias adotadas pelos movimentos sociais para expressar suas demandas podemos destacar as passeatas, as negociações, as mobilizações, os encontros, as denúncias, dentre outros. Os movimentos sociais têm em suas redes de relacionamento, aliados importantes para se pensar soluções de problemas, compartilhar experiências e pensar em novas estratégias. As redes podem ser locais, regionais, nacionais e internacionais, nelas fazem parte movimentos sociais em geral, mas também universidades e outros tantos colaboradores. A internet tem sido importante para a divulgação, denúncia e articulação dos movimentos. Essa comunicabilidade também produz 
novos saberes na medida em que suas ações e discussões acabam circulando por outros espaços.

Para analisar esses saberes, deve-se buscar as redes de articulações que os movimentos estabelecem na prática cotidiana e indagar sobre a conjuntura política, econômica e sociocultural do país quando as articulações acontecem. Essas redes são essenciais para compreender os fatores que geram aprendizagens e os valores da cultura política que vão sendo construídos no processo interativo. (...) Ocorre de duas formas: na interação dos movimentos em contato com instituições educacionais, e no interior do próprio movimento social, dado o caráter educativo de suas ações. (GOHN, 2011, p.333-334).

Os movimentos sociais são inspirados pelas memórias das experiências passadas, porém suas experiências cotidianas também moldam seu modo de agir no presente: "Eles expressam energias de resistência ao velho que oprime ou de construção do novo que liberte. Energias sociais antes dispersas são canalizadas e potencializadas por meio de sua prática em fazeres propositivos." (GOHN, 2011, p.336). Sendo assim, o movimento social consegue aglutinar lutas que antes estavam dispersas, dissipando certa fragilidade frente às forças opressoras.

Os movimentos sociais constroem ações coletivas, que se estendem em uma rede com outros grupos, com o objetivo de resistirem contra a desigualdade imposta por esse modelo de sociedade excludente. Os movimentos sociais empoderam atores da sociedade civil, possibilitando a esses sujeitos atuarem por melhores condições de vida e de se perceberem como parte orgânica de uma luta por uma sociedade mais justa. O diálogo com outros grupos e movimentos permite a esses sujeitos perceberem a dimensão da importância da sua ação coletiva. "Ao realizar essas ações, projetam em seus participantes sentimentos de pertencimento social. Aqueles que eram excluídos passam a se sentir incluídos em algum tipo de ação de um grupo ativo." (GOHN, 2011, p.336). Portanto, os movimentos sociais criam representações simbólicas, muito mais representativas que muitos políticos eleitos. Essas lideranças e movimentos afirmam sua representatividade por meio de ações, discursos e práticas. Alguns grupos sociais consolidam identidades, antes desordenadas ou dispersas, por meio dos movimentos sociais.

Além disso, esses movimentos são movidos por uma demanda socioeconômica - podendo esse ser de caráter variado como: a fome, a casa, o trabalho, a saúde e tantas outras - e ainda por respeito à diferença e à multiculturalidade. Isso pode ser percebido junto às lutas dos movimentos 
quilombolas, indígenas, de mulheres, LGBTs, negros, etc. Diante disso, esses movimentos podem ser percebidos como formadores não apenas de seus membros, mas, sobretudo, da sociedade como um todo na medida em que buscam organizar e conscientizar a população.

O conhecimento do movimento social se estende para além da organização e consciência de grupo, carregando ensinamentos em vários campos. Como exemplo desses ensinamentos, podemos citar o caso do movimento quilombola no qual em sua participação se aprende saberes sobre economia solidária, respeito aos mais velhos, respeito ao meio ambiente, as diferenças culturais, etc.

A autora Gohn chama a atenção para a educação ser constituída por três dimensões: “formal (escolas), não formal (práticas educativas de formação voltadas para a construção da cidadania) e informal (socialização dos indivíduos no ambiente de origem).” (GOHN, 2011, p.346). Em outras palavras, a educação, segundo a autora, compreende outros espaços (não formais ou informais) e não unicamente o formal, caracterizado pelo espaço da escola. A educação ocorre cotidianamente em sociedade, o indivíduo aprende saberes que não são escolares, esses saberes, por sua vez, ao entrarem em contato com a educação formal nos espaços escolares podem ser reforçados, valorizados ou caracterizados como inferiores e/ou negligenciados.

As lutas por direitos, fundamentais para a conquista da cidadania, são partes do processo educativo. Isto é, os movimentos sociais corroboram para a formação educacional dos sujeitos envolvidos no processo por mudanças sociais. O tema dos direitos é central porque possibilita a compreensão das diversas demandas (econômica, política, cultural, etc.) como essenciais para a emancipação ou construção de uma cidadania plena. As leis são compreendidas pelos movimentos sociais como algo mutável, não como algo petrificado, mas como uma construção permanente que deve estar a serviço da justiça social. Esses aprendizados no campo do direito são adquiridos na luta cotidiana dos movimentos sociais. Os direitos, como a educação, são pensados pelos membros do movimento social não com base na ótica do mercado, mas de acordo com as necessidades e experiências históricas dos povos ou grupos sociais. A valorização da cultura local por determinados movimentos sociais, como o quilombola, se contrapõe à lógica do mercado que é de massificar a sociedade com seus produtos culturais. O crivo do direito pode permitir a compreensão das conquistas como 
políticas emancipadoras e não como compensação, compaixão, caridade ou privilégio. A consciência do direito abre brechas para novos movimentos se insurgirem contra a ordem posta como algo natural. $\mathrm{O}$ direito permite desnaturalizar convenções postas para beneficiar determinados grupos sociais.

Movimentos sociais pela educação abrangem questões tanto de escolas como de gênero, etnia, nacionalidade, religiões, portadores de necessidades especiais, meio ambiente, qualidade de vida, paz, direitos humanos, direitos culturais etc. Os movimentos sociais são fontes e agências de produção de saber. $\mathrm{O}$ contexto escolar é um importante espaço para participação na educação. A participação na escola gera aprendizado político para a participação na sociedade em geral. (GOHN, 2011, p. 347).

A autora contribui para a discussão ao mencionar a quantidade de temas tratados pelos movimentos sociais em suas vivências cotidianas. Vale lembrar que alguns desses temas encontram grande resistência por parte de vários setores conservadores da sociedade. Os ambientes escolares também são sufocados por uma onda conservadora que na sua maioria controla as políticas educacionais. Cabe lembrar os inúmeros projetos políticos de grupos conservadores que visam restringir a liberdade de expressão dos professores em sala de aula, como, por exemplo, o recente projeto intitulado "Escola Sem Partido" ${ }^{21}$ que tramita no Congresso Federal. O projeto apresenta uma falsa dicotomia ao se intitular "Escola Sem Partido", pois defende que os professores só poderiam tratar de temas que não sejam contrários à moral dos pais. A pergunta que se coloca é: Como tratar da diversidade religiosa e cultural em um país marcado por uma cultura eurocêntrica, racista, machista e homofóbica?

A articulação dos movimentos sociais organizados (por meio de discussões sociais através de ações, seja via apresentações, protestos ou fóruns) acaba por driblar os mecanismos de controle desses grupos conservadores, propondo discussões contra esse modelo social que aprofunda a desigualdade pelo mundo. Portanto, os movimentos sociais são fontes e agências de produção de saber. Os mesmos estão participando de maneira não formal do processo educacional, seja via ações reivindicativas ou formativas, seja pela exigência de um novo modelo de educação (uma educação outra). A participação na educação por via direta ou

\footnotetext{
${ }^{21}$ Mais informações sobre o debate travado acerca do tema podem ser encontradas nos endereços https://professorescontraoescolasempartido.wordpress.com/https://www.youtube.com/watch?v=J2 v7PA1RNqk
} 
indireta se desdobra em aprendizados políticos que engendra engajamentos de participação na sociedade, por mudanças sociais.

A relação entre movimento social e educação é antiga. Na década de 1960 os ensinamentos de Paulo Freire, apropriados pelas Ligas Camponesas e as Comunidades Eclesiais de Base da Igreja (CEBs) forneciam instrumentos para uma visão crítica da sociedade e, portanto, já formavam sujeitos engajados politicamente em lutas sociais. Na década de 1980, os movimentos sociais ganham maior projeção ao exigirem, no contexto do fim da ditadura militar no Brasil, uma pauta com temas que foram silenciados nesse período, dentre os quais podemos citar a questão étnico-racial, a demarcação de terras indígenas e quilombolas, a democratização da educação, etc.

$\mathrm{Na}$ educação tradicional o aprendizado estava concluído quando o indivíduo conseguia reproduzir o visto em aula, mesmo que essa reprodução fosse desprovida de qualquer sentido para o alunado. "Segundo Vygotsky, o aprendizado ocorre quando as informações fazem sentido para os indivíduos em um dado contexto social." (GOHN, 2011, p. 352). Os movimentos sociais permitem aos seus militantes e à sociedade, de maneira geral, uma maior compreensão das relações de poder que estão em disputa na sociedade. Assim, as informações começam a fazer sentido no momento em que são oferecidos elementos para compreender sua realidade social. Nesse processo, os sujeitos passam a desnaturalizar sua condição social, se percebendo como agentes históricos, isto é, os movimentos sociais podem propiciar uma consciência histórica a seus participantes. $\mathrm{O}$ autor Jörn Rüsen afirma que a "consciência histórica é a realidade a partir da qual se pode entender o que a história é, como ciência, e por que ela é necessária" (RÜSEN, 2001, p. 56). ${ }^{22}$ Essa consciência histórica é importante para poder compreender o passado como um campo de experiência e projetar o presente e futuro enquanto projeto. ${ }^{23} \mathrm{~A}$ militância no movimento social possibilita a compreensão da experiência do processo histórico

\footnotetext{
${ }^{22}$ A consciência histórica não se limita a conhecer todas as experiências históricas, mas contribui para articular passado, presente e futuro. Com base na experiência do presente, os indivíduos buscam compreender o passado em articulação com o presente e, assim, projetar o seu futuro. "É este o caso quando se entende por consciência histórica a suma das operações mentais com as quais os homens interpretam sua experiência da evolução temporal de seu modo e de si mesmos, deforma tal que possam orientar, intencionalmente, sua vida prática no tempo.” (Rüsen, 2001, p. 57)

${ }^{23}$ Segundo Reinhart Koselleck, a "experiência é o passado atual, aquele no qual acontecimentos foram incorporados e podem ser lembrados." (KOSELLECK, 2006, p.310).
} 
de luta das minorias e, com isso, abre caminhos para se pensar em estratégias à construção de um presente e um futuro melhores.

\subsection{Movimento Negro e Movimento Quilombola}

É importante começar explicitando que o movimento quilombola também faz parte do movimento negro. Porém, com a especificidade de ser quilombola, ou seja, de ser constituído na sua maioria por negros oriundos do meio rural. Revisitando a história de articulação entre o movimento negro e o quilombola, é conhecido o fato de que o movimento negro apresentou uma proposta de norma para a Constituinte de 1988 na tentativa de garantir o direito das comunidades negras rurais do Brasil sobre as terras que ocupam há décadas. Como já mencionado no primeiro capítulo, ${ }^{24}$ muitos debates ocorreram até a aprovação do Art. 68 do Ato das Disposições Constitucionais Transitórias (ADCT) na Constituição de 1988.

A pressão do movimento negro possibilitou outras conquistas para os negros, dentre as quais a criminalização do racismo, a criação da Fundação Cultural Palmares (1988), a elevação de Zumbi ao status de herói nacional, a criação do Grupo de Trabalho Interministerial para valorização da População Negra (1995), a criação da Secretaria Especial de Políticas de Promoção da Igualdade Racial (SEPPIR, 2003), dentre outras tantas conquistas. (CARDOSO e GOMES, 2011)

Uma das principais demandas do movimento negro é a ampliação das políticas afirmativas. Cabe destacar que as cotas raciais ainda são questionadas com o argumento de que aos negros são dadas as mesmas condições materiais e sociais para conseguirem ascender socialmente. Isso expõe a máxima social de que vivemos em uma democracia racial, na qual basta que o sujeito se esforce para superar todas as suas dificuldades. A ideia de harmonia racial também é outro obstáculo à aceitação da desigualdade sofrida pelos negros. A perspectiva de harmonia racial tem suas raízes em 1933, quando Gilberto Freyre (2006) publica a obra "Casa Grande e Senzala", na qual descreve as relações entre senhores e escravos como próximas. Segundo o autor, essas relações teriam um caráter benigno, pois impediu grandes divisões raciais no Brasil, se utiliza da mestiçagem

\footnotetext{
${ }^{24}$ Página 19.
} 
como um dos elementos para ratificar tal teoria. Tal fato colaborou para se negar os direitos aos negros por políticas de reparação, esse objetivo é mascarado na ideia de construir uma sociedade sem fissuras sociais, em outras palavras, uma comunidade imaginada, ${ }^{25}$ porém, não condizente com a realidade brasileira.

O direito quilombola deve ser situado dentro de um contexto de pluralização de demandas sociais na cena pública brasileira que emergiram ao longo dos anos de 1980. Nesse contexto de efervescência, por liberdades e direitos, vários atores e grupos se lançam no espaço público desvelando suas angustias, suas singularidades e saindo da invisibilidade. Os quilombolas fazem parte desse grupo que vivia à margem da sociedade, ignorados pelas autoridades por serem negros e por simbolizarem o atraso personificado na imagem do meio rural.

Zélia Amador ${ }^{26}$, militante do movimento negro, expõe a seguir o papel inicial do movimento negro na articulação para construir um movimento dos trabalhadores rurais negros, o que posteriormente, veio a se configurar como movimento quilombola:

Só o fato de tirar essas comunidades da invisibilidade secular já foi um grande avanço. Não foi uma tarefa fácil. Eu sempre digo que o movimento negro tem sido muito generoso com a sociedade brasileira. Tu já imaginaste o que é trazer para a sociedade diversas comunidades, no país inteiro, que estavam invisíveis para ela durante séculos? Isso vai ser de uma importância muito grande para a própria sociedade brasileira começar a rediscutir a sua identidade. E não foi fácil trazê-las à tona. Foi muito difícil, mas agora estão aí, organizados, lutando, os quilombolas." (ALBERTI e PEREIRA, 2007, p. 321).

O movimento negro quilombola possibilitou que muitos trabalhadores negros do campo tivessem suas demandas alçadas para o debate público, saindo, dessa maneira, da invisibilidade na qual se encontravam. Além das demandas sociais, os quilombolas surgem na cena política como sujeitos detentores de saberes e culturas que se querem valorizar. Ao mesmo tempo o movimento quilombola passa a afirmar suas especificidades enquanto movimento negro, ou seja, se afirmam negros e quilombolas.

\footnotetext{
${ }^{25} \mathrm{O}$ autor Benedict Anderson (2008) define nação como uma comunidade política imaginada, ou seja, uma construção que, por muitas vezes, ignora as diferenças, hierarquias e desigualdades sociais.

${ }^{26}$ Participou do Grupo de Trabalho Interministerial para a Valorização da População Negra, formado em 1995 pelo governo federal. Ela foi propositora do sistema de cotas na UFPA, professora do Departamento de Artes da mesma instituição desde 1978.
} 
Pode-se verificar uma tendência no interior do movimento quilombola, tanto nacional (CONAQ) quanto nas entidades estaduais (ACONERUQ, ACQUILERJ e Federação N'Golo), de busca de autonomia em relação ao movimento negro. Duas explicações apareceram de modo mais recorrente e foram utilizadas para justificar a necessidade dessa autonomia. A primeira liga-se ao fato de este grupo étnico ter uma pauta específica, qual seja, a luta por território para grupos que estão em sua maior parte no meio rural, sendo necessário construir um movimento que atenda a essas especificidades. A segunda explicação está relacionada ao temor de que o movimento quilombola ficasse subsumido à ampla pauta do movimento social negro, sendo tutelados demais, fazendo com que os quilombolas ficassem submetidos a uma agenda e pauta definidas pelos movimentos sociais negros. (CARDOSO e GOMES, 2011, p.11).

As diferentes lideranças do movimento quilombola conduziram o processo de discussão, fomento e embates com as autoridades públicas e outros agentes sociais pela demarcação de suas terras. O movimento quilombola colhe os aprendizados do movimento negro e segue em frente com suas peculiaridades na luta contra o racismo e todas as suas mazelas. Nesse sentido, já começam a redefinir seu horizonte de expectativa (Koselleck, 2006), pois são compelidos a compreenderem os diversos meandros da luta política e a lutarem por seus direitos, dentre eles o da terra. É importante destacar que o surgimento do movimento quilombola em diálogo com o movimento negro em geral potencializa as lutas negras no Brasil.

A visibilização pública do direito quilombola se intensificou com as articulações com os mais variados setores sociais, como as ONGs, Universidades e outros movimentos sociais. Assim o movimento foi tecendo relações e aumentando sua capilaridade social e política. O movimento se fortaleceu e se ramificou para outras frentes de luta que não apenas a posse da terra, dentre elas podemos citar: uma educação diferenciada, a valorização da história e da memória dos negros e da África, de uma agricultura sustentável, do combate ao racismo e de políticas afirmativas.

A organização em torno da luta por direitos foi fomentada em várias partes do Brasil por entidades do movimento negro, como: o Centro de Cultura Negra (CCN/MA), no Maranhão; o Centro de Defesa do Negro (CEDEN/PA), no Pará; e o grupo Ylá-Dudu, de Angra dos Reis.

A partir da década de 1990 configura-se uma articulação própria quilombola com contornos nacionais. Em 1995, data emblemática na qual se comemorava os 300 anos da morte de Zumbi dos Palmares, foi realizado, em Brasília, de 17 a 20 de novembro o $1^{\circ}$ Encontro Nacional de Comunidades Negras Rurais. Em maio do ano seguinte, foi criada a Coordenação Nacional de Articulação das Comunidades 
Negras Rurais Quilombolas (CONAQ), em Bom Jesus da Lapa (BA). Pode-se dizer que, desde a criação dessa instância nacional, esse movimento está em processo de articulação. Dois aspectos podem ser indicados como dificultadores para a articulação nacional dessa luta. Um primeiro elemento seria a dificuldade de comunicação, pois qualquer tipo de movimento nacional no Brasil enfrenta essa dificuldade dada à vasta dimensão territorial do Brasil. No caso das comunidades negras de quilombos, esse elemento é agravado pelo fato desses grupos estarem em sua maioria nas zonas rurais. Um outro aspecto está relacionado à ausência de recursos econômicos para que o movimento quilombola consiga intensificar a mobilização nacional. (CARDOSO e GOMES, 2011, p.7)

É importante ressaltar que essa articulação a nível nacional só foi possível devido ao papel das associações de cada comunidade. Sem a organização dos coletivos locais, não seria possível todo esse movimento nacional. Cabe destacar, ainda, o papel de atores com experiência no movimento negro na organização e identificação das comunidades quilombolas. Alguns militantes do movimento negro levaram a discussão do Artigo 68 para as comunidades negras, contribuindo para a organização e autodefinição da comunidade como quilombola.

Enfim, podemos afirmar, com base nessa experiência narrada, que o movimento social produz aprendizados que se estendem para além de seus militantes e territórios. $\mathrm{O}$ conhecimento se propaga à medida que seus indivíduos circulam e trocam experiências sociais: "Quando a produção teórica educacional desconsidera os saberes produzidos pelo Movimento Negro enquanto tais, ela possibilita o desperdício da experiência desse movimento social.” (GOMES, 2017, p. 53). A trajetória dos movimentos sociais, aqui, em especial, o movimento negro e quilombola, é marcada por saberes que foram sendo construídos ao longo da história de luta. No caso do movimento negro, adquiridas no processo de luta contra as desigualdades oriundas do racismo. Esses saberes são compartilhados junto à sociedade, em especial, pelos próprios militantes do movimento negro. Porém, ainda há a necessidade de serem compreendidos como conhecimentos ou saberes a seres ensinados nas Escolas e Universidades.

\subsection{Aprendizados na Militância negra e quilombola}

As leituras realizadas no decorrer dessa pesquisa indicam o quanto as experiências do movimento negro e quilombola são importantes para a construção de uma epistemologia educacional mais democrática. Nilma Lino Gomes (2017) caracteriza o papel educador do Movimento Negro, afirmando que há saberes 
construídos nas lutas por emancipação que, inclusive, deveriam fazer parte do universo escolar. Segundo Santos (2006), há um epistemicídio dos saberes das “minorias". Seus saberes são, por muitas vezes, tratados como inválidos e/ou não científicos, como superstições, desqualificados e até invisibilizados. Diante dessas constatações, na tentativa de identificar alguns dos aprendizados adquiridos na luta por emancipação nesse subcapítulo, utilizarei como instrumento os depoimentos de lideranças quilombolas, do movimento negro no geral e os diálogos com alguns autores. Mas antes, é necessário fazer uma breve consideração sobre as fontes orais. Alessandro Portelli chama a atenção para a importância de como compreender os conteúdos da fonte escrita e oral:

O conteúdo da fonte escrita é independente das necessidades e hipóteses do pesquisador; é um texto estável, que não pode ser apenas interpretado. O conteúdo das fontes orais, por outro lado, depende largamente de que os entrevistadores põem em termos de questões, diálogos e relações pessoais." (PORTELLI, 1997, p.35).

Além disso, é interessante explicitar que "dados extraídos de cada entrevista são sempre o resultado de uma seleção produzida pelo relacionamento mútuo.” (PORTELLI, 1997 p. 36) Nesse sentido, é possível afirmar o caráter inconcluso de trabalhos com fontes orais, já que é impossível extrair completamente a memória de um indivíduo. Por outro lado, a sacralidade da escrita em nossa sociedade leva ao erro, por muitas vezes, de atribuir objetividade às fontes escritas.

Nas entrevistas realizadas, houve a tentativa de compreender o significado de ser militante do movimento quilombola de Santa Rita do Bracuí:

A militância compreende não querer lutar só para você ou só para sua família. A pessoa na militância quer igualdade para todos, então, eu milito para que esse povo, os quilombolas, tenha uma vida igualitária, melhor para todo mundo. (Liderança A do Quilombo de Santa Rita do Bracuí).

Com base nos depoimentos, é possível chegar à conclusão de que a luta dos militantes quilombolas não se encerra após a demarcação de terra da sua comunidade, ela continua para que outras comunidades também assegurem os seus direitos. Além disso, a demanda não se esgota na questão da terra, é uma luta, como no movimento negro em geral, por inclusão do negro no seu sentido mais amplo. O sentimento de pertencimento a uma luta maior, como a dos negros por direitos, é parte dos aprendizados absorvidos no decorrer da militância 
política. O movimento social tem como uma de suas principais características a ideia de que a luta se constrói no coletivo e para o coletivo. Isso enche o indivíduo de um sentimento de valorização, de pertencimento, no qual, sua participação se torna para o movimento, e para o próprio indivíduo, imprescindível. Esse sentimento de empatia, de acreditar que a luta não termina após a demarcação das terras do seu quilombo gera um engajamento por outras demandas relacionadas à justiça social, em especial, as referentes ao negro.

Esse sentimento de pertencimento ficou bem explícito em uma das minhas visitas ao Quilombo de Santa Rita do Bracuí, quando a Liderança A relatou que seus membros e de outras comunidades, recentemente, foram ao Município de Mangaratiba para tentarem auxiliar um quilombo da região. Os moradores deste quilombo vinham sofrendo perseguições e ameaças de uma empresa. Esta controlava a entrada e saída das terras do quilombo com o objetivo de expulsar os seus moradores e ali construir um empreendimento imobiliário de luxo. Outro acontecimento muito lembrado na comunidade do Bracuí foi quando o governo municipal resolveu asfaltar a principal rua de acesso ao quilombo sem a prévia discussão com seus moradores. Alguns jovens deitaram em frente às máquinas que fariam as obras. As lideranças quilombolas entraram em contato com professores de universidades e com o Quilombo do Campinho de Paraty para que fossem até o local e reforçassem o efetivo contra a passagem das máquinas. Depois de muita resistência conseguiram frear o avanço do asfalto. Esse sentimento de pertencimento a uma causa coletiva, que extrapola os limites do território ao qual fazem parte, configura-se como um dos aprendizados importantes:

Com certeza, a gente conhece outros parceiros, outras pessoas que estão na luta. Às vezes grupos em situação melhor que a nossa, que já fizeram mais coisa, outros em situação pior que a nossa. O legal disso é a gente ter um conhecimento, ter um envolvimento, não é só a gente aqui achando que estamos sozinhos, têm outras pessoas com situações em comum com a nossa também, outros territórios, outros quilombos, outras comunidades tradicionais. Então, isso nos faz até continuar mais fortes nessa luta. (Liderança A do Quilombo de Santa Rita do Bracuí).

A militância faz perceber que a luta está conectada com outras demandas e outros grupos sociais, guardadas, obviamente, as especificidades de cada movimento e grupo. Há a compreensão de que a luta será vencida se for construída dentro de um coletivo formado por outros tantos coletivos, seja o 
quilombola, o ambientalista, o professor, o movimento negro em geral, as feministas e outros tantos movimentos sociais. Um dos pontos ressaltados pelas lideranças quilombolas diz respeito, exatamente, às parcerias que são realizadas com outros grupos, instituições e movimentos sociais. Essas parcerias contribuem para fortalecer o movimento, pois há um compartilhamento de experiências que contribuem em termos de conhecimento, mas, acima de tudo, cria-se uma rede de ajuda mútua, de apoio e incentivo. Além disso, esse somatório de lutas possibilita agregar mais vozes, traçar caminhos em comum e estratégias para cada demanda:

Nos fortalecemos enquanto comunidade, fazemos parcerias, principalmente, quando conhecemos outra comunidade tradicional, seja quilombola, caiçara ou indígena. Conseguimos vê [sic] que nossa luta tem muita coisa em comum, em especial, o território. (Liderança B do Quilombo de Santa Rita do Bracuí)

A autora Gohn (2011) caracteriza esse processo de aprendizagem como prática. Ou seja, os quilombolas na militância aprendem como se organizarem, pensarem em estratégias de luta e caminhos a percorrem. Uma das primeiras ações pensadas pelos grupos que se autodeclaram quilombolas é a fundação de uma associação de moradores na comunidade. Com o objetivo de organizar o grupo, a associação cumpre um papel educativo muito importante que é de organizar as discussões, mas acima de tudo, de educar os moradores na comunidade através de oficinas e encontros na busca de parcerias por melhorias sociais, culturais e até materiais. Cabe destacar o Ponto de Cultura do Bracuí que tinha oficinas para crianças com várias atividades culturais, como a leitura de histórias, Jongo e rodas de conversa.

Além disso, podemos citar os contatos das associações quilombolas com as Universidades e outros parceiros como parte desse processo de formação e fortalecimento. Nos movimentos sociais em geral têm ocorrido o ingresso de muitos jovens em cursos acadêmicos. Na maioria das vezes, esses jovens retornam para a comunidade com o objetivo de continuar lutando pela demanda dos seus grupos. Por muitas vezes, a escolha do curso é influenciada pelas necessidades do grupo. No caso do Bracuí, o curso de Educação no Campo tem sido uma das escolhas dos jovens quilombolas e, na sua maioria, são esses mesmos jovens que participam mais ativamente na militância do quilombo.

A Liderança A destacou em uma conversa a participação do Quilombo do Bracuí nos congressos e fóruns ligados a discussões por mudanças na educação, 
meio ambiente, turismo, etc. Essa participação está muito associada a pressões do próprio movimento que exige sua presença, compreendendo que sua participação é importante e um direito inalienável. A participação no movimento social pode permitir ao cidadão compreender o patrimônio público como público, as políticas públicas são entendidas como direitos e não como benesses do governo. Essa experiência é educativa para seus membros, mas, também, para outros sujeitos e grupos na medida em que circulam e trocam experiências. Cabe ressaltar a participação do Movimento Quilombola do Bracuí no Conselho de Educação do Município de Angra dos Reis. O conhecimento desses códigos é fundamental para se estabelecer estratégias por políticas sociais.

Gohn (2011) caracteriza essa aprendizagem como técnica instrumental, que está ligada à compreensão de como está organizada a burocracia estatal, assim como seus órgãos governamentais, trâmites e leis. Esse conhecimento é adquirido na luta cotidiana do movimento quilombola, uma formação contínua e necessária para os movimentos sociais e para toda a sociedade. A aquisição desse conhecimento empodera os sujeitos envoltos em disputas por melhores condições de vida, por respeito à diferença e valorização cultural. A pressão social do movimento social permite, inclusive, o diálogo com governos e, consequentemente, a influência em decisões políticas dos mesmos, espaços governamentais aos quais antes não tinham acesso.

A Liderança $\mathrm{C}$, quando perguntada sobre os aprendizados adquiridos na militância do movimento quilombola do Bracuí, ressalta o papel das lideranças mais experientes no processo de formação de novas lideranças, enfatizando o empoderamento e/ou autoestima:

Para você ter ideia, eu era muito tímida, não conseguia falar em público. A Angélica era quem falava por todos. Ela quem falou para mim: Olha, você pode! Eu consegui perder a timidez, não totalmente, mas parte. Você precisa de algum conhecimento. Eu conseguia lutar por todos, representar em uma roda de conversa com a participação de professores. Foi muito bom, hoje eu tenho outra visão de sociedade. Como minha mãe falou para mim: Meu Deus, podia desligar a televisão porque eu não consigo assistir o jornal, você não para de falar! Em relação aquilo que a mídia coloca, eu tenho outra visão, você consegue ser mais crítica, mais política, não político partidário, mas o político de outra forma. (Liderança C do Quilombo de Santa Rita do Bracuí)

Uma das principais aprendizagens adquiridas pelo grupo é a política. Por meio dela se adquire a consciência dos direitos e dos atores que dificultam e 
usurpam os direitos. A politização é, provavelmente, um dos aprendizados mais importantes na militância do movimento social, em especial, o quilombola. A consciência política de que as mudanças só ocorrerão por meio de ações coletivas, a identificação e a dedicação por uma causa é um elemento de coesão na medida em que esses sujeitos se percebem como agentes importantes para mudarem a sociedade. A força está na coletividade, na ideia de que juntos somos fortes e separados somos fracos. O sujeito deixa a inércia, ou melhor, a passividade para adentrar no movimento, o indivíduo se vê como importante para frear essa engrenagem social que desqualifica, inferioriza, hierarquiza e marginaliza diversos grupos e sujeitos, em especial, o negro. A Liderança A ressalta como um dos principais aprendizados a consciência do conhecimento e da força que a comunidade tem para o enfrentamento político:

É saber lutar. É saber lutar com as armas que temos. Não é arma de fogo não. Mas as armas da própria força! Às vezes as pessoas se acham muito fracas, digo fraco em conhecimento, mas aí com os encontros, com o movimento a gente vai vendo que a gente tem muito conhecimento, muita força, muita sabedoria e as pessoas vão acordando para isso, vão vendo que o que ela antes achava que era coisa banal, na verdade, não é. São as armas bem fortes para que nós continuemos na luta, essa luta que não para, mas que se reforma, vamos dizer assim. Quando você pensa que terminou aquela luta, ela pode reaparecer de outro jeito, com outro modo de lutar. Isso faz com que as pessoas passem a abrir os olhos para isso, elas vão vendo que tem que ir se modificando, e, assim, os conhecimentos também. Nossa grande arma nessa luta é mesmo o conhecimento! (Liderança A do Quilombo de Santa Rita do Bracuí).

Quando perguntado sobre como ocorreu o processo de engajamento na militância do movimento quilombola de Santa Rita do Bracuí, outra liderança afirma que ocorreu de forma natural e processual, ou seja, houve aprendizados que foram se constituindo nas experiências cotidianas da comunidade, como o Jongo que transmite saberes e o passado histórico da escravidão.

Acho que foi um processo muito natural, da própria formação de militância daqui. Se perguntarmos aos mais jovens, acho que eles também não saberão falar exatamente, porque isso é um processo que vai sendo trabalhado na mente dessas pessoas desde cedo, no envolvimento, de certa forma, na própria militância direta ou indiretamente. Por exemplo, pelo Jongo. Então a pessoa está ali no Jongo, ouve falar de quilombo e acaba se envolvendo, quando vê já está lá dentro. (Liderança B do Quilombo de Santa Rita do Bracuí).

Se por um lado, é possível perceber na pesquisa a não existência de apenas um motivo para o engajamento na militância política de um movimento social, uma vez que as experiências coletivas e individuais exprimem as ações dos 
agentes, isto é, "história oral não tem sujeito unificado; é contada de uma multiplicidade de pontos de vista" (PORTELLI, 1997, p. 39), por outro, o depoimento da Liderança B nos permite concluir também que a dinâmica local, as vivências, de forma direta ou indireta, podem ter grande influência no envolvimento, na participação dos sujeitos na militância.

A Liderança B coloca a seguir como aprendizado do movimento quilombola a compreensão do que caracteriza as comunidades tradicionais, como o convívio em comunidade, os aspectos culturais, o pertencimento à terra e ao território, a militância, etc. O movimento quilombola potencializa esse aprendizado ao ressaltar a importância de tal aprendizado em uma sociedade cada vez mais materialista e individualista:

Eu acho que esse convívio de comunidade é um aprendizado. Entender o que são as comunidades tradicionais, entender as manifestações culturais dessas comunidades (inclusive aqui no Bracuí temos o jongo como exemplo de instrumento dessas práticas culturais) para se fazer valer o pertencimento à terra, ao território e à luta de militância quilombola, é muito importante para a comunidade. [...] Quando nos reconhecemos como comunidade tradicional, somos recebidos bem em todos os lugares. Esse conviver em comunidade (que não é só o movimento que ensina) já é uma prática nossa, mas o movimento está ali enfatizando e vivenciando o tempo todo. $\mathrm{O}$ estarmos na casa do outro, colhendo algo na casa do outro, de viver mesmo em comunidade. Mas, obviamente, se formos colocar o movimento como um todo, nós aprendemos a militar, aprendemos a defender o território, a nossa terra. (Liderança B do Quilombo de Santa Rita do Bracuí)

Outro elemento mencionado por Gohn, percebido nos depoimentos, são os aprendizados teóricos, associados a conceitos que são aprendidos na militância política. Segundo a autora, a apropriação desses conceitos é de extrema importância para a construção do movimento social. "Aprendizagem teórica: quais os conceitos-chave que mobilizam as forças sociais em confronto (solidariedade, empowerment, autoestima), como adensá-los em práticas concretas." (GOHN, 2011, p. 352-353). Os conceitos são carregados de significados históricos que possibilitam o entendimento do processo e das disputas em jogo. As apropriações desses conceitos contribuem para o empoderamento dos sujeitos e corroboram para mobilizar forças sociais dos seus membros e de outros grupos. Dentre os conceitos de extrema importância para o movimento quilombola estão: Quilombo, Comunidades Tradicionais, quilombola, Negritude, Território, Ancestralidade, dentre outros. Enfim, a compreensão dos conceitos 
possibilita a ressignificação das identidades locais, a compreensão histórica, o empoderamento e novas adesões.

É interessante mencionar que existem muitas convergências entre os inúmeros quilombos no que diz respeito à organização e aspectos culturais, mas também há divergências que tornam os diferentes espaços singulares. A compreensão dos aspectos culturais como algo positivo pode lançar o sujeito na compreensão de sua realidade. Mas, sobretudo, possibilitar maior valorização da cultura afro-brasileira, ressaltando-a como algo a ser respeitado, como valor social. (PEREIRA E ROZA, 2012).

Esse somatório de lutas nos permite pegar parceiros para trocarmos experiências, saberes. Tem coisas que eu quero saber que minha avó fazia e que eu não consegui pegar, mas na outra comunidade tem gente que faz aquela prática que a minha avó fazia, aí tem como eu pegar lá e trazer para cá. Enfim, é essa revitalização de saberes e agregar mesmo, porque sozinho a gente não chega a lugar nenhum. (Liderança B do Quilombo de Santa Rita do Bracuí).

Como a liderança B afirma no trecho acima, há uma "revitalização de saberes" que ocorrem na troca. Algo que foi esquecido ou perdido em um determinado grupo pode ser lembrado na troca com outros grupos tradicionais quilombolas, caiçaras e indígenas. Isso vai ao encontro do que Boaventura (2010) chamou de "ecologia de saberes" que seria a valorização dos diversos conhecimentos, dentro de uma relação horizontal. As comunidades quilombolas não hierarquizam seus aspectos culturais ou inferiorizam outros grupos, mas sim, tentam estabelecer uma relação de respeito à pluralidade cultural dentro do movimento e também fora dele.

A Liderança B coloca a seguir suas demandas no campo dos direitos, suas especificidades, trajetórias, exigem políticas específicas:

Porque existe muita gente que tem dinheiro e que comanda esse país desde quando o Brasil era colônia, desde quando escravizavam os nossos, que não quer que a gente tenha direitos e quer nos diluir nessa sociedade, trazendo uma falsa democracia. Nós batemos o pé e dizemos que não, que somos populações específicas e que queremos os nossos direitos específicos, de fazer práticas específicas no nosso território! O nosso território é específico, cada comunidade tem a sua especificidade. (Liderança B do Quilombo de Santa Rita do Bracuí).

O conceito de comunidade quilombola está associado, em especial, ao de comunidade tradicional. Uma comunidade tradicional tem um conjunto de vivências e práticas culturais que exigem, por parte do poder público, políticas 
diferenciadas. Nesse sentido, os aspectos culturais da comunidade são de suma importância para a conquista de direitos. Isso permitiu a essas comunidades um olhar diferenciado sobre suas próprias vivências, referenciais culturais, histórias e sobre sua identidade negra.

\subsection{Memória e Identidade:}

Um dos importantes aprendizados, identificados ao longo da pesquisa, do movimento quilombola está ligado aos usos da memória como um elemento político importante na luta por suas demandas. Nesse sentido, cabe destacar a discussão em torno do "dever de memória", expressão construída ao longo dos anos 1980, associada à obrigação do Estado e da sociedade para com os detentores de memórias de sofrimento e opressão. Essa questão acerca de passados sensíveis tem colocado a estreita relação entre história e memória no centro de debates recentes. A evocação do dever de memória teria começado nos anos de 1970 quando houve uma ressignificação da memória do Holocausto. Nesse sentido, "o dever de memória seria não apenas o dever de manter vivo o passado, mas, fundamentalmente, a ideia de que um reconhecimento é devido àqueles que sofreram”. (HEYMANN, 2006, p. 7). A memória, algo até então particular de um indivíduo ou grupo, ganharia uma maior projeção e/ou um valor social que deveria ser compartilhado e reconhecido. Os sujeitos que tiveram suas vidas marcadas por esse passado deveriam ser reconhecidos e suas memórias preservadas.

A luta do movimento quilombola não é apenas pela terra, mas por uma memória pública que tire o negro de uma condição de subalternidade e passe a encará-lo pela valorização de sua história e cultura, em especial, do quilombola. Uma história que por muito tempo foi silenciada ou negativizada. A memória coletiva e individual dos quilombolas é potencializada pelo movimento quilombola na comunidade e na sociedade em geral.

É importante explicitar que a memória ocupa um papel importante na construção de identidades pessoais e sociais. A memória está associada à maneira como nos relacionamos com o nosso passado, como construímos nossa identidade e nos diferenciamos dos outros. 
Radicam da subjetividade, embora cada eu só ganhe consciência de si em comunicação com os outros, pelo que a evocação do que lhe é próprio tem ínsitas as condições que a socializam. A memória individual é formada pela coexistência, tensional e nem sempre pacífica, de várias memórias (pessoais, familiares, grupais, regionais, nacionais, etc.) em permanente construção devido à incessante mudança do presente em passado e às conseqüentes alterações ocorridas no campo das re-presentações do pretérito. (CATROGA, 2001, p. 16).

As memórias dos quilombolas emergem da subjetividade, mas é na relação com o outro que se ganha consciência de si. A identidade e a memória são temas recorrentes em função do lugar de destaque que ocupam, pois muitos grupos fundam, também, sua existência em uma memória compartilhada. A ascensão dessas identidades no cenário público traz em seu âmago uma urgência por reconhecimento de sua memória. Ou seja, a luta por direito abrange o reconhecimento dessa memória, um reconhecimento que passa pela necessidade de revisão das interpretações históricas:

entre as lutas por direitos, ganha lugar a luta por manter viva essa memória, mas também por conquistar espaço no discurso histórico a partir de uma revisão das interpretações sobre o passado, por figurar nos livros e manuais escolares, por ver-se incluído no calendário oficial de comemorações, reivindicações que têm como objetivo reparar o silêncio e a invisibilidade que, muitas vezes, marcaram a vida dessas coletividades, e promover a sua integração à história da nação a partir de uma nova perspectiva. (HEYMANN, p. 3, 2006).

Não se trata do uso da memória quilombola que faça referência ao sofrimento da escravidão, mas, sobretudo, no tocante ao processo de luta e resistência do negro no Brasil. O acionamento da memória foi o que garantiu a sobrevivência das suas trajetórias individuais e coletivas. A manutenção dessa memória, transmitida dos mais velhos para os mais jovens, assegurou, além da sobrevivência cultural, a sobrevivência material. Ou seja, a memória foi um elemento de extrema importância no processo de elaboração dos relatórios antropológicos para a titulação como comunidade quilombola pela fundação Palmares e, consequentemente, a possibilidade de lutar pela demarcação de suas terras, por políticas de salvaguarda cultural e por uma educação escolar quilombola. Então, podemos afirmar que a memória é um elemento fundamental para o currículo de uma educação quilombola, tendo em vista que os saberes e tradições locais foram garantidos pela memória via oralidade. Dessa forma, como afirma em depoimento a liderança A do Quilombo do Bracuí: "a história local deve 
ser repetida várias vezes porque a história oral funciona assim, é de tanto repetir que se aprende."

Essa compreensão do conceito de história oral ajuda a sistematizar a memória local no sentido de compreender aquilo que há muito tempo seus antepassados já faziam, isto é, transmitir, perpetuar a história da comunidade por meio da oralidade em função da pouca valorização de suas histórias pela história oficial. Portelli enfatiza a seguir a relevância da história oral para esses sujeitos:

Fontes orais são condição necessária (não suficiente) para a história das classes não hegemônicas, elas são menos necessárias (embora de nenhum modo inúteis) para a história das classes dominantes, que tem tido controle sobre a escrita e deixaram atrás de si um registro escrito muito mais abundante. (PORTELLI, 1997, p. 37).

Desta maneira, seus membros, assim como os membros de outros grupos tradicionais, encontraram na história oral o meio para manterem vivo o seu passado, suas memórias. Enfim, suas histórias de luta e resistência, fazendo da oralidade sua arma de resistência pela posse da terra e por uma narrativa que valorize sua cultura e história. O movimento quilombola tem em suas memórias e nas suas vivências o combustível que alimenta o seu horizonte de expectativa, isto é, o seu projeto de uma sociedade menos desigual. As trajetórias de resistência contra a escravidão, de luta pela terra e por suas memórias são sempre utilizadas como elementos pedagógicos contra o racismo e suas mazelas sociais.

A Liderança C do movimento quilombola de Santa Rita do Bracuí resume tais ideias ao afirmar que: "a gente tem que aprender que muitos morreram lutando [...] a nova geração tem que se manter na luta, apesar das dificuldades." Os quilombolas destacam a importância da valorização dos antepassados e do legado deixado. Dentre os quais, podemos destacar o respeito aos mais velhos, a valorização do Jongo, da vida em comunidade, do respeito à terra, da solidariedade, etc. Essas memórias estão sendo recordadas na comunidade para demonstrar o quanto suas trajetórias e lutas atuais estão ligadas ao passado de seus antepassados negros. É importante destacar que o presente é um ponto de encontro entre a recordação e a esperança, a recordação seria o campo de experiência e a esperança o horizonte de expectativa ou de projeto (Kosseleck, 2006). Por isso, a memória tem a ver com passado, presente e futuro, ou seja, a memória deve ser pensada sempre dentro dessa tridimensionalidade. 
O movimento quilombola compreende que o esquecimento de suas memórias na história oficial faz parte de um projeto político racista. O esquecimento não foi acidental, mas parte de um plano de dominação, hierarquização e branquitude. Nesse sentido, Andreas Huyssen afirma que o esquecimento precisa ser compreendido não apenas como complemento ou deficiência da memória, mas como um "fenômeno de múltiplas camadas que serve como a própria condição de possibilidade da memória." (HUYSSEN, 2014, p.155). Sendo assim, “a política da memória não pode prescindir do esquecimento." (HUYSSEN, 2014, p.160). Esse aprendizado nutriu no movimento negro o desejo por reparações, como o direito de que suas memórias submersas venham à tona, sejam estudadas e valorizadas. Huyssen entrelaça essa relação entre o esquecido e o lembrado: “O esquecimento precisa ser situado num campo de termos e fenômenos como silêncio, desarticulação, evasão, apagamento, desgaste, repressão - todos os quais revelam um espectro de estratégias tão complexo quanto à própria memória." (HUYSSEN, 2014, p. 158).

O esquecimento fez parte da história do Brasil e do mundo como uma política deliberada. A história está marcada por censuras, apagamentos, destruição de documentos, alteração de fontes, etc. Esse apagar está associado a projetos políticos de grupos ou de Estado. A História do Brasil é marcada por essas práticas, em especial, no que diz respeito ao negro. Não apenas sua cultura negra sofreu um processo de apagamento, mas a própria existência física do negro esteve ameaçada com a política do Estado brasileiro de embranquecer a população. É mais difícil construir uma narrativa de algo apagado do que se lembrar do esquecido.

É importante ressaltar que na comunidade do Quilombo do Bracuí, mesmo antes da identificação como quilombolas, já havia práticas que visavam "dar futuros ao passado, numa atividade de re-presentificação.” (CATROGA, 2001, p.23). Tais expressões se materializavam por meio do Jongo, da contação de histórias, das festas e dos traços do passado via monumentos erguidos na comunidade. Esses reavivamentos estão presentes até os dias de hoje nas memórias locais, funcionando como suportes materiais, sociais e simbólicos das memórias. As memórias e seus suportes podem servir como fronteiras que separam e hierarquizam, mas, também, como um espaço de trocas socioculturais, reforçando o sentimento de pertencimento: "uma memória estruturada com suas 
hierarquias e classificações, uma memória também que, ao definir o que é comum a um grupo e o que o diferencia dos outros, fundamenta e reforça os sentimentos de pertencimento e as fronteiras sócio-culturais." (POLLAK, 1989, p.3).

Cabe mencionar nesse trabalho o exemplo de um importante projeto intitulado Passados-Presentes, em desenvolvimento atualmente na comunidade de Santa Rita do Bracuí, que caminha na direção de manter viva e conhecida a memória local dessa comunidade. Esse projeto foi criado pela Universidade Federal Fluminense (UFF) em parceria com os quilombolas do Bracuí e caracteriza-se como um roteiro de lugares de memória local. Suas lideranças, compreendendo esses lugares como monumentos importantes para a compreensão da história local, partiram do pressuposto de que sua manutenção é fundamental para que a recordação não seja apenas imaginação. Os traços organizam e dão sentido para a vida dos indivíduos e do grupo, funcionam como um elemento pedagógico para a comunidade e para o grande público. O projeto, inclusive, foi utilizado no ano de 2017 pela Prefeitura de Angra, que passou a enviar turmas de escolas do Ensino Fundamental para conhecerem a comunidade quilombola e parte do roteiro do Projeto Passados-Presentes. É importante frisar que essa iniciativa da prefeitura não contou com nenhum financiamento. As lideranças questionavam o fato de não haver uma verba para o projeto e a prefeitura afirmava que não havia recursos para isso. A Liderança A, contrariando a opinião de alguns colegas de militância, resolveu receber as turmas mesmo sem nenhuma ajuda financeira. Essa liderança relata que tomou tal iniciativa em nome da educação e da história local, compreendendo que o esquecimento seria muito pior. Segundo essa liderança, sua história precisava ser compartilhada. Somente recordando e divulgando as suas memórias seria possível construir e reconstruir outras referências de monumentos e, consequentemente, afirmar suas memórias na sociedade.

A divulgação abre margem para a dialética daquilo que é lembrado e esquecido pela "memória oficial". Os alunos ao se depararem com essas memórias subterrâneas podem perceber as ausências e, assim, refletirem acerca das problemáticas que circunscrevem a temática da história negra no Brasil. Os indivíduos, ao conhecerem essas memórias locais, podem compreender que o ato de escolher é também um ato de esquecer, silenciar e excluir. É nesse sentido que a história oral cumpre um papel importante na resistência contra essa "memória 
oficial”, por cumprir um papel de salvaguarda dessas memórias subterrâneas: “A história oral e as memórias, pois, não nos oferecem um esquema de experiências comuns, mas sim um campo de possibilidades compartilhadas, reais ou imaginárias.” (PORTELLI, 1996, p.8).

Ao privilegiar a análise dos excluídos, dos marginalizados e das minorias, a história oral ressaltou a importância de memórias subterrâneas que, como parte integrante das culturas minoritárias e dominadas, se opõem à "memória oficial", no caso da memória nacional. [...] essas lembranças durante tanto tempo confinadas ao silêncio sobre o passado, longe de conduzir ao esquecimento, é a resistência que uma sociedade civil impotente opõe ao excesso de discursos oficiais. Ao mesmo tempo, ela transmite cuidadosamente as lembranças dissidentes nas redes familiares e de amizades, esperando a hora da verdade e da redistribuição das cartas políticas e ideológicas. (POLLAK, 1989, p.4-5).

Essa dialética entre o recordar e o esquecimento pode contribuir para os pesquisadores das ciências sociais entenderem que não existe memória dos indivíduos com esquecimentos absolutos e nem passados inteiros. Além disso, o estudo das memórias dos quilombolas, por meio da história oral, possibilita perceber os limites de uma história nacional, ou seja, evidencia "os limites desse trabalho de enquadramento". ${ }^{27}$ Sendo assim, "novos traços podem despertar lembranças esquecidas, e novas alterações situacionais do evocador podem levar a "reescrever o que nunca se esqueceu" (CARTROGA, 2001, p. 30). Nada está petrificado no ato de recordar ou de esquecer. A memória é projetiva e mutável. A memória tem o poder de recriar futuros para o passado e futuros para o presente. O fato de boa parte da sociedade atual viver em um presente contínuo, sem nenhuma relação orgânica com o passado, impede de perceber o tempo presente enquanto processo histórico. A historiografia deveria cumprir o papel de contribuir para a desconstrução da concepção de um passado petrificado e de um presente acabado

O passado não pode ser acessado como realmente foi, pois não há como voltar no tempo. O que existem são representações desse passado, marcados por relações de poder, negociação e resistência. A lembrança é uma construção

\footnotetext{
${ }^{27}$ Michael Pollack (1989, p.12), ao estudar a memória das minorias, percebeu haver uma tentativa de "enquadramento da memória", ou seja, um projeto de criar uma memória coletiva nacional por meio de relações desiguais de poder. Esse processo de enquadramento, por muitas vezes, esconde projetos de poder e dominação de determinados grupos ou indivíduos. Ao mesmo tempo o autor identifica que há, por parte dos marginalizados, uma resistência ao enquadramento de suas memórias.
} 
permanente, banhada na experiência presente, ou seja, a memória é trabalho. Daí a necessidade de fornecer materiais que possibilitem outras representações do passado acerca da história do negro no Brasil. O movimento quilombola expõe suas memórias como parte de materiais que possam contribuir para a construção de uma memória pluricultural. Dito em outras palavras, para fomentar representações que estavam ou estão restritas a memórias de grupos, por muitas vezes, esquecidas em função de memórias concorrentes com maior poder social. A Liderança B chama a atenção para a importância da compreensão histórica oriunda do processo de participação no movimento quilombola:

A gente passa a entender o processo histórico do país. A gente passa a se vê [sic] como uma pessoa negra. Quando eu morava no Morro da Caixa d'água o meu pai sempre teve a afirmação de dizer que eu era uma pessoa descendente de pessoas que foram escravizadas dentro dessa fazenda de Santa Rita de Bracuí. Naquela situação, eu não tinha a clareza de que fazenda era essa, que era dos Breves, um dos donos das maiores terras do país. Enfim, eu não tinha essa clareza, mas tinha a de que eu era uma pessoa negra, sim, isso eu já sabia desde quando eu tinha uns 5 ou 8 anos de idade. Saber que sou negro era uma coisa, outra coisa é você ter uma identidade quilombola, isso eu não tinha (embora o termo quilombola seja um termo novo, porém, de uma identidade de práticas que são, digamos, milenares. Porque o quilombo não é uma coisa do Brasil ou foi inventado com a escravidão na América, isso já era coisa que veio desde o próprio continente africano). (Liderança B do Movimento Quilombola de Santa Rita do Bracuí).

Tal participação pode permitir ao sujeito desnaturalizar sua condição e perceber-se como um agente importante para mudar sua condição e da sociedade. A liderança B afirma, no trecho citado anteriormente, que já se reconhecia como negro por conhecer a história de escravização de seus antepassados. O processo histórico quando conhecido pode contribuir para o sujeito afirmar sua negritude e sua identidade quilombola. A Liderança B também enaltece a importância dos aprendizados da militância do movimento quilombola nesse processo de consolidação, ressignificação e valorização da identidade negra e da cultura afrobrasileira:

Essa identidade negra que a gente adquire com a militância no movimento, nos leva a desconstrução de diversas coisas. Por exemplo, eu mesmo era um cara que nasci em uma família cristão-católica e hoje eu sou candomblecista. Isso eu adquiri ao longo do movimento, até porque eu tinha um senso comum, como todo mundo tem que demonizava o Candomblé. Hoje eu estou dentro daquilo que me tinha sido negado e que só tive acesso, de verdade, na atuação no movimento quilombola. 
A Liderança B menciona abaixo como o movimento quilombola vem contribuindo para uma positivação da história do negro no Brasil, se distanciando das representações tradicionais que colocam o negro em uma condição de subalternidade e contribuindo para uma positivação e, consequentemente, uma maior afirmação da identidade negra e quilombola:

\begin{abstract}
Essa identidade quilombola, que de certa forma a gente precisa assumir como quilombola que é para garantir direitos, é muito legal por esse quesito de você afirmar uma identidade negra onde ela é vista de uma forma em que o negro é tido como quem teve como, ou que contribuiu, nessa sociedade para a construção do Brasil, na construção das Américas. Não apresentando a representação do negro de forma negativa, como as escolas fazem, como submisso. Na verdade, não somente as escolas, mas os filmes, onde os negros são chicoteados no pelourinho, são submissos, estão sempre servindo ao senhor. A identidade quilombola te fortalece com um pensamento de que foram as mãos negras que construíram o Brasil que hoje a gente tem, até porque eram os nossos antepassados que plantavam, construíam as coisas. A influência linguística, assim como dos povos originários, os indígenas. Há muitas contribuições fortes que nos são negadas o tempo todo, como se a gente não tivesse feito nada. É sempre estávamos ali servindo, acabou a escravidão, viramos marginais e hoje a gente vende droga. Um contexto histórico onde até a venda de drogas foi, de certa forma, imposta por uma visão eurocêntrica, uma prática bem excludente dessas minorias, onde as oportunidades faltam. (Liderança B do Movimento Quilombola de Santa Rita do Bracuí).
\end{abstract}

O depoimento da liderança $\mathrm{B}$ nos permite pensar sobre como as identidades entram em constante mudança, na medida em que as pessoas agregam novas experiências às suas vidas. Nesse sentido, cabe ressaltar, mais uma vez, o fato das comunidades negras rurais passarem a redefinir suas identidades com o advento do Artigo 68, que estabelece o direito sobre as terras ocupadas aos remanescentes dos escravizados que ainda ocupem as mesmas terras de seus antepassados negros. Esse novo espaço de experiência das comunidades negras ressignifica suas identidades individuais e coletivas. Não se trata mais, exclusivamente, de uma comunidade negra, mas de uma comunidade de negros quilombolas. A autora Heymann expressa como os mecanismos jurídicos mencionados ao longo do capítulo I (Artigos 68, 215, 216 e os Decretos 3.551 e 4.887) fizeram emergir novos sujeitos políticos que passam a se apoderar de identidades que, por muitas vezes, foram silenciadas e negadas, ressignificando com isso suas identidades individuais e coletivas:

centenas de comunidades negras rurais, em pouco tempo, solicitaram sua identificação como remanescentes de quilombos, deixando entrever como o reconhecimento jurídico pode estar na base de processos de ressurgência de 
identidades ocultadas ou desaparecidas, sendo importante fator na constituição de novos sujeitos políticos. (HEYMANN, p. 22, 2006).

Estão em disputa novas formas de auto-identificação, de valorização de histórias particulares que rivalizam com narrativas nacionais e homogeneizadoras. O contexto atual é marcado por lutas de grupos que desejam o reconhecimento público da importância de suas histórias e culturas para a nação, mas, sobretudo, que esse reconhecimento das suas singularidades, seja acompanhado de direitos. Esse processo de ressignificação das identidades das comunidades quilombolas é caracterizado por Gohn como uma aprendizagem cultural:

Aprendizagem cultural: quais elementos constroem a identidade do grupo, quais suas diferenças, sua diversidade, as adversidades culturais que têm de enfrentar, qual a cultura política do grupo (seu ponto de partida e o processo de construção ou agregação de novos elementos a essa cultura) etc. (GOHN, 2011, p. 352-353).

Com base nas entrevistas das lideranças, é possível afirmar que a construção de uma identidade quilombola contribuiu para o empoderamento da identidade negra na comunidade de Santa Rita do Bracuí. A Liderança B explicita o papel dessa identidade quilombola na comunidade do Bracuí:

Não somos só negros, somos negros e quilombolas ou quilombolas negros. Enfim, essa identidade fortalece muito. Aqui a comunidade sempre se reconheceu como uma comunidade negra rural, depois desse processo quilombola, ela se reconhece como comunidade negra rural quilombola de Santa Rita do Bracuí. Isso altera porque dá ênfase a uma negritude com outro olhar. Essa negritude precisa ser fortalecida para que a gente consiga ter uma autoestima, consiga se valorizar como pessoas negras. Têm também as questões específicas de território, da ancestralidade, isso é bem específico quando você é um quilombola, pois você passa a se reconhecer não só como negro, mas como um negro quilombola. Isso tem uma influência na nossa própria identidade, até porque o Brasil passou por um processo histórico onde tudo aquilo que é nosso sempre foi negado ou visto como coisa ruim. Um exemplo é o cabelo, cabelo negro, cabelo afro, crespo eram tidos como uma coisa ruim. Eu lembro quando o movimento quilombola explodiu, teve esse "bum" com oficinas, as pessoas visitando mais fizeram com que assumissem mais o seu cabelo "Black". As pessoas começaram a pegar essa identidade quilombola e trazer para elas: Olha, eu sou quilombola sim! As pessoas começaram a ver nas práticas ancestrais coisas boas, positivas, então, viram que ter os traços africanos, negros, era coisa legal. Os próprios meninos passaram a andar de "Black". Meninos que antes só cortavam o cabelo de máquina, ou seja, o corte de negão era careca, mas os meninos assumiram essa identidade negra. Hoje em dia a gente vê as meninas fazendo a transição de cabelo. A questão da cor da pele mesmo: não sou pardo, não sou moreno, nem mulato. Sou negro. Essa identidade negra vai se ressignificando, se fortalecendo através do próprio movimento quilombola, até mesmo quanto ao pertencimento de território. Aqui, como é tido como uma área rural, as pessoas não tinham essa visão de ficar aqui, a ideia era sempre de ir para fora. Os mais novos tinham a visão de sair daqui. Hoje não! Hoje se tem a ideia de que há como viver aqui, 
porque as pessoas conseguem enxergar a beleza desse lugar que foi preservado por esse próprio convívio de centenas de anos da nossa própria família, do nosso núcleo familiar. (Liderança B do Quilombo de Santa Rita do Bracuí).

A identidade quilombola é muito recente. Ela vem se somar à identidade de comunidades rurais negras e descendentes de escravizados com a possibilidade de demarcação de suas terras. Mas até hoje, no Bracuí, nem todos os seus membros se identificam como quilombolas ou aceitam o fato das terras serem tituladas como coletivas e não particulares. Alguns começam, gradualmente, a se reconhecerem como quilombolas, outros renegam porque já julgavam difícil carregar a identidade negra, agora teriam que ser negros e quilombolas. Muitos se distanciavam porque julgavam que tudo associado ao negro era negativizado ou inferiorizado. A Liderança A colocou a dificuldade das pessoas aceitarem sua própria identidade negra e quilombola.

Depende de pessoa para pessoa. Têm uns que é mais rápido, tem uma consciência elevada, aceitam mais rápido. Outros são muito coerentes naquilo que eles acham que deve ficar bem escondido, que ninguém deva saber, apesar de que a cor da pele mostra que a pessoa é negra. Mas a cabeça não quer dizer que a pessoa é negra. Só o tempo... Isso vai mudando com o tempo. Alguns começaram a ver que ser quilombola não é tão negativo assim como via no início. Eles achavam que ser quilombola, para além de ser negro, ia os levar mais ainda para a negatividade. Mas agora as pessoas já aceitam com mais facilidade o fato de ser negro e ser quilombola. (Liderança A do Quilombo Santa Rita do Bracuí).

Na negação da negritude ou da identidade quilombola há o fato de se querer negar toda herança negra com o discurso de que mexer nisso só aumenta o preconceito. Parte-se do pressuposto de que vivemos em uma democracia racial, afirmando que o racismo é algo do passado. A memória dos antepassados permanece viva no mesmo grupo, porém, a apropriação desse passado é completamente diferente de sujeito para sujeito. Nessa direção, podemos afirmar que as diversas memórias nem sempre terão o mesmo significado para diferentes sujeitos. O que ocorre até mesmo dentro do mesmo grupo. No caso do movimento quilombola, há os que irão se afirmar enquanto quilombolas e outros que irão negar tal identidade.

A negação da identidade negra ou quilombola é uma postura compreensível, tendo em vista que a sociedade brasileira é marcada pelo racismo, incrustado em uma mentalidade marcada pela branquitude, na qual ser branco ou adotar uma cultura dita branca é o referencial. (PEREIRA, 2012). Isso fica 
explícito no relato de Frei Davi $^{28}$ quando o mesmo foi alertado de que sofria de uma doença chamada de "ideologia do embranquecimento" (ALBERTI e PEREIRA, 2007 p. 50). Segue um trecho de seu depoimento:

Ali, em 1976, começou o despertar da consciência racial, a leitura crítica das relações raciais no Brasil e o quanto isso estava muito mal resolvido, o quanto isso era uma fonte de estrago de vida, porque o bonito é a pessoa se amar conforme Deus o criou. E se eu vivia aquilo, comecei a me perguntar: "como é que vivem os demais negros?". E descobri que todos os negros do seminário eram poucos, éramos oito, comigo - também negavam sua cultura racial. E comecei, na sociedade, na cidade, em reuniões, aonde eu ia, tentava me aproximar de pessoas negras e puxar o tema do negro. E descobri que, de cada dez, nove não queriam nem papo sobre esse assunto. Então eu percebi que a rejeição estava em grau exageradamente forte, era um problema, um problema nacional. Decidi que a partir dali eu não queria ser franciscano porque São Francisco tem uma proposta de vida e tem um projeto de sociedade. Eu queria ser franciscano porque eu queria botar essa estrutura de Igreja e de franciscano a serviço de um assunto que não é bem trabalhado, que é questão do negro. (ALBERTI e PEREIRA, 2007, p. 51).

Essa ideologia do embranquecimento permeia todo o tecido social até os dias atuais, por isso, se faz necessário o engajamento em trabalhos que façam suscitar a consciência racial na sociedade, em especial, no próprio negro já que boa parte nega sua negritude. Jurema Batista ${ }^{29}$ relata que foi no contato com o movimento negro que começou a compreender a questão racial: "A vida inteira eu bebi na tal história de que no Brasil não tinha racismo..." (ALBERTI e PEREIRA, 2007, p. 54). No trecho abaixo, em depoimento, Magno Cruz ${ }^{30}$ expressa como é complicada a questão da identidade negra no Brasil e como o movimento negro contribuiu para seu engajamento no CCN (Centro de Cultura Negra do Maranhão):

E eu era crente que eu era moreno. Essa questão de identidade é muito complicada, não é? Eu não dizia que não ia porque não me considerava negro. Mas no fundo eu tinha essa resistência. Pensava: como ia participar de uma entidade do movimento negro se eu não me considerava negro? Mas, com os seminários e com as palestras, que houve muito, eu fui mudando. (ALBERTI e PEREIRA, 2007, p. 55).

\footnotetext{
${ }^{28}$ Participou da formação dos Agentes Pastorais dos Negros e do Grupo de União e Consciência Negra, criados nos anos de 1980. Também colaborou para a formação do Pré-vestibular para negros e Carentes (PVNC) e fundou o Educafro (Educação e Cidadania de Afrodescendentes e Carentes) nos anos de 1990.

${ }^{29}$ Participou da fundação do Nzinga (coletivo de mulheres Negras) em 1983.

${ }^{30}$ Foi Presidente do Centro de Cultura Negra do Maranhão (CCN) nos anos 1980.
} 
A rejeição à identidade negra e a preferência pela nomenclatura "moreno" é, até os dias atuais, uma forma de fugir da nomenclatura negro que é carregada de negativização, inferiorização, escravização, subalternização, fealdade e sujeira, etc. A pele mais clara é apresentada quase como um troféu por jovens em escolas e outros espaços sociais. Os relatos de militantes negros demonstram como é arrancada dos negros a sua própria identidade negra de forma muito perversa, um processo histórico de longa data que impregna o imaginário social até os dias atuais. Josilene Brandão, ${ }^{31}$ militante da causa quilombola, mostra no seu depoimento um dos inúmeros aprendizados desse diálogo com o movimento negro. Em sua fala expõe o processo de seu empoderamento negro e de autoestima enquanto negra, em especial, enquanto mulher negra:

Em meados dos anos de 1980, o Centro de Cultura Negra do Maranhão, CNN, realizava os primeiros encontros de comunidades negras... E foi um momento marcante, porque era eu me descobrindo enquanto negra. Porque tinha a coisa de ser "morena" na família, mesmo sendo negra... Quando entrei naquele auditório, tudo era negro, eram negros e negras. Era como se eu tivesse entrado e me visto. Foi a sensação, que eu guardo até hoje: de ter me visto ali. Eu digo que foi o lugar em que eu me achei, porque me vi igual àquelas pessoas. É a questão da autoestima: era como se eu tivesse me encaixado naquele lugar muito bem... E também é a primeira vez que eu me sentia uma mulher negra e bonita, porque eu olhava as mulheres parecidas comigo e muito bem arrumadas... É o momento em que descubro a minha própria identidade, de saber de onde eu vim e tal. Então foi o momento mais bonito da minha vida de militância, porque ali conheci pessoas, conheci o movimento e aprendi muitas coisas da vida que tinha diferente, como, por exemplo, "ser morena". O que era isso? Havia muitos debates sobre "ser negro". (ALBERTI e PEREIRA, 2007, p.57).

O movimento negro ocupa um papel central nesse processo de conscientizar e problematizar a questão racial. O movimento negro e o quilombola foram felizes na sua estruturação porque propuseram o debate acerca do que é "ser negro" e "ser quilombola". O racismo foi estruturado dentro de um pensamento hegemônico e, por isso, só pode ser combatido com um pensamento contrahegemônico. O movimento negro e o movimento quilombola partem dessa proposição contra-hegemônica ao construírem agendas de debates, cursos, encontros e manifestações aos seus membros e à sociedade em geral. Eles empoderam seus membros com o discurso antirracista, com autoestima e outros tantos saberes e aprendizados. Essa inter-relação entre os movimentos acabou por

\footnotetext{
${ }^{31}$ Foi assessora da Associação das Comunidades Negras Rurais Quilombolas do Maranhão (Aconeruq), criada em 1990. Integrava a Coordenação Nacional de Quilombos (Conaq) em 2005, época da entrevista. A Conaq foi fundada em 1996.
} 
possibilitar o que Boaventura vem a chamar, e defender como necessário, um diálogo intercultural:

O trabalho de tradução visa esclarecer o que une e o que separa os diferentes movimentos e as diferentes práticas, de modo a determinar as possibilidades e os limites da articulação entre eles. Dado que não há uma prática social ou um sujeito coletivo privilegiado em abstrato para conferir sentido e direção à história, o trabalho de tradução é decisivo para definir, em concreto, em cada momento histórico, quais as constelações de práticas com maior potencial contrahegemônico. (SANTOS, 2006, p.118).

O autor tem por objetivo incentivar a tradução intercultural, que seria a construção de diálogos em torno de pontos comuns entre os diferentes movimentos. As demandas dos movimentos são muitas, cabe aos atores sociais identificarem, no seu tempo, quais são as ações e as demandas com maior urgência, ou seja, com maior potencial contra-hegemônico. No caso do movimento quilombola e do movimento negro, em geral, seria o estabelecimento de uma agenda de lutas comuns. Uma luta pautada em temas com maior potencial contra-hegemônico. Um desses pontos mais agudos seria o combate ininterrupto contra o racismo:

Logo, os ativistas negros e quilombolas estariam colaborando conjuntamente para construção de uma sociedade que valorize personalidades históricas negras da mesma maneira que valoriza seus heróis "não-negros". Uma frase conhecida diz o seguinte: "bom seria uma sociedade que não necessite de heróis". Reelaboramos da seguinte forma: "bom seria uma sociedade em que todos são heróis", no entanto, enquanto houver pessoas transformadas em "heróis" "igualmente bom seria" uma sociedade que valorize o herói negro da mesma maneira que o branco. (CARDOSO e GOMES, 2011, p. 13).

Os autores chamam atenção para a necessidade de refletir acerca da questão de Stuart Hall (2003): Que cultura negra é essa? Essa questão se torna importante para refletirmos acerca da cultura quilombola, mas, em especial, compreender a diversidade dentro dessa "unidade". É importante estar atento a essa questão para não cair em essencialismos ou em homogeneidades. Nesse sentido, cabe mencionar o projeto de uma escola quilombola que não se pauta em ensinar uma cultura genuína, mas de mostrar a diversidade da cultura, dando voz aos silenciados e marginalizados.

Enfim, essas aprendizagens dependem do envolvimento nas demandas sociais do grupo. É preciso estar envolvido e conhecer a realidade social de maneira crítica. Esse envolvimento exige uma ética que é construída na vivência 
em comunidade, centrada no bem comum, ou seja, em valores comunitários. É importante ressaltar ser essa uma relação de "mão dupla", isto é, a comunidade alimenta o movimento social com seus saberes e, ao mesmo tempo, o movimento leva seus aprendizados adquiridos na militância para a vivência em comunidade. Em suma, tudo se configura como um vasto conhecimento que se adquire na vivência da comunidade que, no entanto, só é potencializado, sistematizado e consolidado na participação e envolvimento no movimento social.

\section{Considerações Finais:}

O silêncio em torno do passado negro pode ser um obstáculo epistemológico, mas também pode ser um elemento problematizador para a pesquisa historiográfica e para a reflexão em geral, pois o silêncio está ligado a relações de poder, a enquadramento de memórias e silenciamentos. Sendo assim, “... memória e historiografia se encontram com a consciência da dívida (Paul Ricouer), isto é, com o imperativo de também dar a palavra aos que, quando vivos, já estavam condenados ao silêncio" (CATROGA, 2001, p.49). Quanto maior for a dimensão da memória social, maior serão os esquecimentos. A memória dos oprimidos exige que se confronte os consensos das memórias coletivas, há a necessidade da descontinuidade para que memórias submersas possam emergir. As recordações são apenas a ponta do "iceberg" das inúmeras memórias que poderão surgir a qualquer momento. Catroga expressa à importância da historiografia para valorizar e determinar o devido lugar das inúmeras memórias das minorias (negros em geral, negros quilombolas, mulheres, homossexuais, indígenas, caiçaras, etc.) que foram esquecidas em detrimento dos projetos de nação constituídos ao longo da história do Brasil.

a historiografia, com suas escolhas, valorizações e esquecimentos, também gera a "fabricação" de memórias, pois contribui, através do seu cariz narrativo e da sua cumplicidade, direta ou indireta, com o do sistema educativo, para o apagamento ou secundarização de memórias anteriores, bem como para a refundação, socialização e interiorização de novas memórias. (CATROGA, 2001, p.57).

No caso específico dos quilombolas, é importante destacar o papel das memórias quilombolas para o processo de ensino aprendizagem como elemento importante para suas lutas, mas, também, para a cultura histórica em geral, uma vez que contribuem com saberes que não são encontrados na história oficial, 
muito menos em outros meios difusores dessa mesma cultura histórica, principalmente se considerarmos o processo de exclusão histórica sofrido pelos negros quilombolas. Com base nesse pressuposto de consciência histórica, podemos afirmar que o movimento quilombola compreende a educação escolar quilombola como necessária para o processo de democratização e valorização dos seus saberes e da cultura negra. A luta por uma educação escolar quilombola foi uma decisão política importante, pois o movimento negro percebeu que o espaço escolar também é importante na luta por uma cultura histórica que respeite e valorize a cultura negra e o negro, em especial, o quilombola. Sendo assim, é possível afirmar que a luta do movimento quilombola por uma educação escolar quilombola se constitui como um dos aprendizados desenvolvidos na militância política. Além disso, é interessante perceber que esses aprendizados do movimento negro e quilombola podem e devem fazer parte dos currículos escolares, em especial, das escolas quilombolas.

É importante destacar a importância do currículo de história nesse processo de tomada de consciência histórica. Segundo Frei Davi: "a consciência histórica é o primeiro passo para o despertar de consciência" (ALBERTI e PEREIRA, 2007, p.191). Frei Davi afirmava que o movimento negro se preocupava em utilizar como prática pedagógica o processo histórico do negro no Brasil. Para ele, didatizar tal processo era municiar os negros e a população para um despertar da consciência da questão racial no Brasil. O movimento negro, de maneira geral, também reconhece a importância de didatizar os aprendizados do movimento negro e quilombola para a consciência histórica e, consequentemente, para a construção de uma sociedade mais justa. Daí a luta do movimento quilombola e negro por uma educação escolar que incorpore seus aprendizados. 


\section{Capítulo III - Áurea Pires da Gama: Educação Escolar Quilombola e um Currículo em Construção}

Esse trabalho tem como um dos seus compromissos compreender o processo de luta por uma educação quilombola no Quilombo de Santa Rita do Bracuí, entendido como um microcosmo da luta por uma educação emancipatória do movimento quilombola e negro. É interessante explicitar, mais uma vez, que a luta por uma educação quilombola constitui um dos aprendizados do movimento negro, em especial, quilombola. É preciso "reconhecer o papel do Movimento Negro na construção de um projeto educativo emancipatório" (Gomes, 2017, p. 38). Dentro desse processo, há demandas diversas, como a luta do movimento quilombola negro por uma educação diferenciada, ou seja, uma educação associada à realidade de cada território quilombola.

O autor Santomé afirma que "As instituições escolares são lugares de luta, e a pedagogia pode e tem que ser uma forma de luta político-cultural". (SANTOMÉ, 1995, p. 175). Essa ideia despertou o interesse por identificar a importância dos professores participarem no processo de construção de propostas educacionais alternativas, como a elaboração de currículos diferenciados, multiculturais e a construção de materiais escolares. Este capítulo, ao dar voz aos educadores e lideranças, pretende identificar caminhos, possibilidades para a construção de um currículo quilombola para a escola Áurea Pires da Gama a partir das próprias experiências desses sujeitos.

Um currículo para uma educação quilombola deve estar a serviço de desconstruir conceitos que alimentam a desigualdade histórica sofrida pelos negros, quilombolas, indígenas e outros grupos e indivíduos. Se, por um lado, a educação escolar quilombola tem como um de seus objetivos desconstruir o racismo que impregna o imaginário social; por outro, tem a responsabilidade de trabalhar conceitos que se encontram fora dos muros da escola, dentre os quais se encontram as questões do território e dos saberes tradicionais. Portanto, um currículo quilombola tem que cumprir com esse duplo papel, de desconstruir e construir conceitos que possibilitem uma sociedade mais democrática. A luta do movimento negro por educação tem um largo rastro, dentre os quais a educação quilombola e a coloca como um de seus desdobramentos, processo que envolveu diversos atores, em espaços e tempos distintos. 
Ao longo da década de 1990 começa a aparecer nas normatizações do MEC noções de cultura, diversidade cultural, identidade e relações étnico-raciais. Esse novo lugar político e social não seria possível sem o protagonismo do movimento negro, que parece ter percebido que as normatizações são campos de disputa importantes para a adoção de possíveis políticas educacionais inclusivas. O processo de construção do currículo, principalmente o de História, passa a ser para o movimento negro um instrumento importante à revisão do papel do negro na História do Brasil. Pereira chama atenção, no trecho abaixo, para a presença de intelectuais e ativistas negros na elaboração e participação, ao longo da década de 1990, dessas normatizações. Isso explicita o quanto os negros foram atores ativos nesse processo.

Esse novo 'lugar político e social', conquistado pelo movimento, tornou possível até mesmo a participação direta de intelectuais e ativistas negros no processo de construção de novas políticas curriculares no Brasil do final do século XX. Encontramos, por exemplo, lideranças negras atuando como consultores na elaboração dos Parâmetros Curriculares Nacionais (PCNs) de História, que foram divulgados pelo Ministério da Educação em 1998. (PEREIRA, 2012, p. 116)

Sem essa revisão dos conteúdos do currículo tradicional de história seria difícil construir uma sociedade antirracista que valorize a pluralidade cultural. A história ocupa um papel importante nessa luta antirracista, pois deve contribuir à desnaturalização do processo histórico, mostrando que as culturas ditas superiores estão dentro de um quadro de relações de forças. Um currículo que tenha como eixo a desconstrução da naturalização dos processos históricos é de extrema importância para uma sociedade multicultural e à luta antirracista. Silva, no trecho abaixo, deixa claro a importância de uma educação das relações étnico-raciais:

A educação das relações étnico-raciais tem por alvo a formação de cidadãos, mulheres e homens empenhados em promover condições de igualdade no exercício de direitos sociais, políticos, econômicos, dos direitos de ser, viver, pensar, próprios aos diferentes pertencimentos étnico-raciais e sociais. Em outras palavras, persegue o objetivo precípuo de desencadear aprendizagens e ensinos em que se efetive participação no espaço público. Isto é, em que se formem homens e mulheres comprometidos com e na discussão de questões de interesse geral, sendo capazes de reconhecer e valorizar visões de mundo, experiências históricas, contribuições dos diferentes povos que têm formado a nação, bem como de negociar prioridades, coordenando diferentes interesses, propósitos, desejos, além de propor políticas que contemplem efetivamente a todos. (SILVA, 2007, p. 490).

É um grande desafio desenvolver políticas educacionais, processos de aprendizagem e ensino em sociedades multiétnicas e pluriculturais, ainda mais, 
em uma sociedade racializada. Daí a relevância da Lei 10.639/03, que tem como um dos seus objetivos fomentar práticas e estudos pedagógicos que tratem das tensas relações étnico-raciais que marcam o cotidiano da sociedade brasileira. Nesse sentido a história ocupa um papel extremamente importante, por demonstrar os diferentes processos históricos, na tentativa de desnaturalizar as relações sociais, permitindo a desconstrução do mito da democracia racial e demonstrando como a sociedade brasileira projeta-se como branca.

Nesse contexto de luta por uma educação das relações ético-raciais, surge, na década de 1990, o movimento quilombola com a proposta de uma Educação Escolar Quilombola. Uma educação pensada com a participação das comunidades tradicionais negras, com um projeto político-pedagógico voltado para suas realidades históricas e sociais. Nos anos 1990, o movimento quilombola luta por uma normatização diferenciada, pois entende que sua realidade social exige isso. Daí o movimento quilombola negro passa a lutar por Diretrizes Curriculares Nacionais para uma Educação Escolar Quilombola.

A educação escolar quilombola tem uma ancoragem legal que começa com a Lei 10.639/03, que se desdobra nas Diretrizes Curriculares Nacionais para a Educação das Relações Étnico-Raciais e para o Ensino de História e Cultura Afrobrasileira e Africana em 2004. Em 2009, o MEC aprova um Plano Nacional de implementação dessas diretrizes. É importante frisar ser a Lei 10.639 bastante abrangente porque não diz respeito apenas à cultura Afro-brasileira e africana, mas a qualquer pertencimento étnico-racial.

No caso da educação quilombola, o movimento negro quilombola aparece como ator central no processo de fomentação e elaboração das Diretrizes Curriculares Nacionais para a Educação Escolar Quilombola na Educação Básica. O documento das DCNs, iniciado em 2011, na Câmara de Educação Básica (CEB) do Conselho Nacional de Educação (CNE), com a participação do movimento quilombola, estabelece orientações ao sistema educacional com o propósito de criar projetos político-pedagógicos em conformidade com as realidades, vivências e história das comunidades quilombolas do Brasil. Desse processo de luta do movimento quilombola originaram-se o Parecer CNE/CEB 16/2012 e a Resolução CNE/CEB 08/2012 que normatizam diretrizes para uma educação escolar quilombola. Essas medidas são oriundas de demandas históricas 
por uma educação escolar quilombola e, por isso, devem ser pensadas como uma conquista do protagonismo do movimento negro, em especial, o quilombola.

A educação escolar quilombola é uma ação afirmativa, seu objetivo é corrigir desigualdades sociais históricas que afligem determinados grupos. Cabe ressaltar o protagonismo do movimento quilombola no CONAE/2010 (Conferência Nacional da Educação) que reivindicou uma educação escolar quilombola como modalidade da Educação Básica. Em função disto, no texto das diretrizes gerais da Educação Básica aparece pela primeira vez a educação quilombola enquanto modalidade. Após isso, ocorrem os encaminhamentos para a regulamentação dessa nova modalidade que desdobra nas Diretrizes Curriculares Nacionais para Educação Escolar Quilombola na Educação Básica, em 20 de novembro de 2012. Essa nova modalidade implica em se repensar as outras modalidades no sentido de atender às demandas das comunidades quilombolas, como a EJA e a educação profissional.

Nessa direção, podemos falar de um diálogo entre educação quilombola e educação escolar. O movimento percebe como a estrutura de aprendizagem controla os conteúdos, compartilha valores e contribui para se aprender a pensar individualmente e coletivamente. O movimento quilombola coloca em evidência o currículo e o sistema educacional ao pleitear uma educação escolar quilombola.

\subsection{Escola Áurea Pires da Gama e Educação Escolar Quilombola.}

$\mathrm{Na}$ tentativa de compreender esse contexto de luta, cabe lançar um olhar sobre as Diretrizes para uma Educação Escolar Quilombola que, por sua vez, explicita a importância da construção coletiva das propostas. O que implica também em ouvir os atores envolvidos no processo de construção de propostas que configuram a Escola Áurea Pires como escola quilombola. A primeira questão que se colocou aos entrevistados foi o porquê da escolha da Escola Áurea Pires da Gama para a implementação de uma escola quilombola. A Liderança B justifica a escolha com base nas DCNs para uma Educação Escolar Quilombola:

\footnotetext{
Alguns jovens começaram a ter contato com as DCNs para uma Educação Escolar Quilombola quando faziam Educação do Campo na Universidade Rural, depois trouxeram a discussão para a comunidade de se pensar a Áurea Pires como uma escola quilombola. Aliás, a Áurea Pires já era uma escola quilombola segundo os DCNs, só que não sabíamos porque não conhecíamos. Até porque ela diz que escola quilombola são aquelas que estão dentro do território e a Âurea Pires está
} 
dentro do território que a gente pede ao INCRA para ter o título. Foi a partir desse momento que a comunidade começou a pensar sobre a Áurea Pires ser uma escola quilombola para se implementar as diretrizes da educação básica escolar quilombola.

A Liderança B nos permite compreender que a Escola Áurea Pires já era quilombola, em função de estar dentro do território quilombola, independente se em termos pedagógicos ainda não se efetivou um Projeto Político Pedagógico adequado à modalidade. Coloca, também, o vínculo histórico da escola com a comunidade quilombola, destacando que a escola foi criada para atender à comunidade:

Eu passei pela escola Áurea Pires, as pessoas mais velhas têm essa memória que a Áurea Pires foi montada para as pessoas que moravam no Bracuí. Os nativos que eram quilombolas, afirmaram que ali do lado tinha um barracão para estocar banana e mandar embora. Lá tinha uma salinha de aula de alfabetização. Depois se construiu o prédio que hoje é a Áurea Pires, que na época se chamava, eu acho, de outro nome. Eu acho que a comunidade não sabe até hoje quem foi Áurea Pires. A escola deveria ter o nome mais representativo da Comunidade, como Joana Azevedo, que era a Parteira da comunidade quilombola. Teria um peso maior.

A escola é parte desse território quilombola, logo, também é parte da história dessa comunidade. A caracterização da escola como quilombola abre precedentes para novas demandas, como a ressignificação do espaço escolar, inclusive, com a possibilidade de se debater a mudança do nome da escola para um nome ligado à história da comunidade, que para a Liderança $\mathrm{B}$ seria muito mais representativo. ${ }^{32} \mathrm{~A}$ Liderança A aponta como se deu esse processo de escolha:

Então, aqui não tinha escola em toda essa região do Bracuí, foi a primeira escola a ser construída. A escola que tinha mais próxima era a do Frade, nem no Ariró tinha escola. A escola foi construída para a comunidade, nós fizemos uma discussão e o sim ganhou para que a escola fosse incluída no território como quilombola. O fato do Bracuí e a escola ter crescido fez com que muita gente defendesse que a escola não correspondia mais para uma educação quilombola. Nós fomos mostrando às pessoas que não era nada disso. Então, a escola Áurea Pires acabou ficando dentro do território. A escola atendia à comunidade Negra Rural no passado, ainda não tinha esse título de quilombo. Ela atendia ao sertão e à região da praia (os caiçaras).

O depoimento da Liderança A nos permite perceber que não havia um consenso entre os próprios quilombolas que participaram da discussão para definir se a escola deveria fazer parte do território a ser demarcado. Porém, ao analisarem

${ }^{32} \mathrm{O}$ nome da escola é uma homenagem a poetisa e professora angrense Áurea Pires da Gama (1876-1949). 
o processo histórico, identificaram o quanto a história da comunidade e da escola se entrelaçam. Nesse sentido, a escola pertence ao território porque sua história de existência se cruza com a história desse território. A escola pode ser inclusive considerada como espaço de resistência na medida em que foi criada para atender, inicialmente, à comunidade quilombola antes mesmo de se identificarem enquanto quilombolas. Sendo assim, a escola está dentro do território, na medida em que é parte importante desse território à reprodução cultural e social. Suas memórias coletivas e individuais perpassam pela experiência escolar na Áurea Pires da Gama, assim como seria impossível falar da história da escola Áurea Pires da Gama sem se remeter à história do quilombo. Cabe explicitar que a ideia de pertencimento da escola à comunidade quilombola também foi algo ressaltado nas entrevistas dos educadores. A Educadora $\mathrm{B}^{33}$ também contribui para o debate ao ressaltar que a escola foi incluída após muito esforço dos quilombolas:

Eu achei muito bonito esse processo de legalização do território que já passou por várias fases, a certificação do Instituto Palmares - já houve uma medição aqui. É claro que o território não é original, já perdeu muito terreno. Quando eles se reuniram para fazer essas medidas, eles também não tiveram aquele sangue nos olhos de medir tudo e querer tirar todo mundo. Eles quiseram evitar o máximo possível de conflitos e evitar tirar pessoas que já moram aqui, por isso, que existem as ilhas do Quilombo. Existem alguns territórios que pertencem ao quilombo que são verdadeiras ilhas e a escola faz parte das seis ilhas do Quilombo - eles fizeram questão que a escola fizesse parte do Quilombo.

$\mathrm{Na}$ tentativa de acelerar o processo e não entrar em conflito com as famílias de posseiros que moram há muito tempo na região, os quilombolas resolveram por bem não pleitear a titulação das terras na sua totalidade original, ou seja, a demarcação acabou por não ser contínua, tendo diversas ilhas. A escola entrou no território como uma ilha. Esse esforço foi realizado antes da escola entrar no censo como quilombola, isso demonstra o valor histórico que a escola tem para a comunidade de Santa Rita do Bracuí.

As DCNs para uma Educação Quilombola são taxativas ao frisar como dever dos governos assegurar escolas dentro do território quilombola. Cabe enfatizar que, como dito acima, a Escola Áurea Pires da Gama só está dentro do

\footnotetext{
${ }^{33} 40$ anos; graduada e mestre em Educação; cursando doutorado na mesma área; especialista em Diversidade Cultural e Interculturalidade: matrizes indígenas e africanas na educação brasileira; especialista em Psicopedagogia e Orientação Educacional; especialista em Alfabetização das Classes Populares; educadora desde os 16 anos; Pedagoga da Prefeitura de Angra dos Reis desde 2008; integrante da equipe gestora da escola Áurea Pires da Gama desde 2016 e militante do Movimento Negro.
} 
território porque os quilombolas a incluíram como uma ilha, não havendo por parte do governo um movimento de assegurar tal direito a essa comunidade. Daí a necessidade, já apontada pelos entrevistados, de construção de uma escola, de preferência pré-escolar e de primeiro segmento do ensino fundamental, no interior do quilombo. As DCNs quilombolas além de definirem escola quilombola como sendo aquelas que estão dentro do território, também atribuem a tal modalidade aquelas "que atendem estudantes oriundos de territórios quilombolas" (DCNs quilombolas, 2012, Título III, Art. 9º parágrafo II, p.7).

Já a Liderança $\mathrm{C}$ ressalta a importância dos trabalhos realizados a partir da realidade local, na escola, para sua identificação oficial como quilombola:

Na verdade, a Áurea Pires já havia trabalhado com a história local na década de 90 , projeto Paulo Freire pela realidade local. (...) Então, quando veio as DCNs, no dia 20 de novembro, a gente queria colocar essa questão na escola. As DCNs vinham dizendo que dentro do território quilombola a escola pode se identificar como quilombola. Então, porque não se identificar como quilombola? Já que houve um trabalho no passado - o trabalho não foi construído agora - já que houve esse resgate da memória, feito há alguns anos atrás, por que não voltar? Por que não entrar nesse debate? Como nos formamos em 2014, resolvemos levar esse debate para escola, tentando trabalhar a história local e colocar no PPP atual.

Esses trabalhos, desenvolvidos na escola Áurea Pires da Gama na década de 1990, mesmo não tendo sido dado continuidade após mudanças de direções, marcaram a comunidade escolar ao ponto dos mais jovens, que não vivenciaram tal período, reproduzirem essa memória como se tivessem vivido, e alguns professores de forma isolada continuaram a trabalhar temas locais. Essa memória empoderou os quilombolas a lutarem por uma educação quilombola na escola Áurea Pires da Gama.

A pesquisa entrevistou as lideranças do quilombo de Santa Rita do Bracuí e os educadores da Escola Áurea Pires com o objetivo, também, de compreender o que entendiam por educação escolar quilombola. Essa indagação é importante porque possibilita identificar as convergências, divergências e envolvimento desses atores nesse processo. Cabe destacar que o depoimento dos educadores ocorre após uma trajetória que incluiu uma formação continuada de 180 horas na escola Áurea Pires da Gama, entre os anos de 2014 e 2015, que visava permitir conhecer a história local e inseri-los na discussão sobre educação quilombola. $\mathrm{O}$ curso foi ministrado por lideranças quilombolas e professores da Universidade Federal Rural do Rio de Janeiro. A organização dos encontros foi realizada em 
parceria com alguns educadores da Escola Áurea Pires da Gama, por meio de um GT (grupo de trabalho). Esse curso se desdobrou na inclusão da escola no Censo de 2015 como Escola Quilombola e em uma incipiente discussão sobre Currículo diferenciado. A discussão sobre esses temas será retomada ao longo desse capítulo, porém, é importante mencioná-la para dimensionar o momento de tais depoimentos, tendo em vista que ideias e posições pessoais são influenciadas por experiências históricas.

$\mathrm{O}$ depoimento do Educador $\mathrm{D}^{34}$ expõe a urgência de se dialogar com a comunidade ao definir aquilo que entende por educação quilombola: "No ideal, deveria ser uma escola onde a comunidade fizesse muito mais parte do que em uma escola tradicional, como tomar decisões de organização, participação em eventos e na vida escolar diária”. As DCNs para uma Educação Quilombola põem como um dos seus objetivos:

IV - assegurar que o modelo de organização e gestão das escolas quilombolas e das escolas que atendem estudantes oriundos desses territórios considerem o direito de consulta e a participação da comunidade e suas lideranças (Título I, Art. $7^{\circ}$, parágrafo IV, p. 4-5)

As diretrizes para uma educação quilombola expressam algo caro para as populações negras no Brasil e as camadas populares, que seria a participação nos processos políticos. Em especial, os ligados à educação. A educação quilombola tenta quebrar com esse paradigma ao dar protagonismo aos educadores e à comunidade nos processos de decisão da escola. A Educadora G, ${ }^{35} \mathrm{em}$ consonância com a colocação anterior, coloca a comunidade quilombola no centro, ao dizer que a educação quilombola deve ser pensada a partir do prisma do território: “a proposta seria pensar a educação a partir de um território que é quilombola, de forma que não fosse puramente uma educação formal, digamos colonizadora que nós temos, que nós carregamos na nossa pedagogia escolar historicamente".

É importante pensar território não como uma unidade uniforme, mas como espaço de circulação, de trocas e de sobrevivência material e cultural. Nessa

\footnotetext{
${ }^{34} 33$ anos, graduado em História e pós-graduado (lato sensu) em Culturas Africanas e Indígenas, professor de História da Escola Áurea Pires da Gama desde 2009 e da Secretaria de Educação do Estado do Rio de Janeiro desde 2011.

3531 anos, graduada e mestre em Geografia, cursando Doutorado em Geografia, professora de Geografia na rede privada no ano de 2010 e professora de Geografia na Escola Áurea Pires da Gama desde 2016.
} 
direção as DCNs para educação quilombola definem os territórios tradicionais como "II - espaços necessários à reprodução cultural, social e econômica dos povos e comunidades tradicionais, sejam eles utilizados de forma permanente ou temporária" (Art. 5, DCNs para a Educação Escolar Quilombola, p. 4). Os quilombolas se autodeclaram como comunidades ou povos tradicionais. O que significa serem detentores de aspectos diferenciados em relação à cultura, à organização social, de conhecimentos baseadas na tradição e assentados em territórios. Se o território é a base da existência econômica, cultural e social da comunidade, logo, quilombo e território são indissociáveis. Adotar uma pedagogia escolar do território quilombola teria a função de contextualizar a partir do próprio território. Ou seja, iria territorializar esses sujeitos com base na experiência da comunidade e do movimento social:

Os movimentos sociais nos puxam para radicalizar o pensar e fazer educativos na medida em que nos mostram sujeitos inseridos em processos de luta pelas condições elementaríssimas, por isso radicais, de viver como humanos. (...) eles nos remetem ao perene da condição humana: a terra, o lugar, o trabalho, a moradia, a infância, a sobrevivência, a identidade e diversidade de classe, idade, raça ou gênero. (ARROYO, 2003, p. 36-37)

Uma pedagogia para uma escola quilombola deve convergir com a pedagogia do movimento social quilombola no que diz respeito à emergência de educar para transformar as condições de desigualdade. O depoimento da Liderança A segue nessa direção ao explicitar o que entende por educação quilombola:

Para mim seria educação escolar quilombola o aluno ou a pessoa com quem ele vai estudar recebendo uma educação plural, ou seja, a governamental e a Educação do próprio ser dele, na família, do próprio território onde ele vai aprender a ser um integrante e compreender o porquê disso. Muitas vezes as pessoas sabem que tem aquilo, como a luta, mas não compreendem. Então, na escola, desde pequeno, como se fosse o berço, começa a aprender sobre o seu ser, sua própria vivência, o seu território e também porque não dizer passa a amar aquilo que a pessoa tem, aquilo que a pessoa é. Então, aprender desde pequeno, como as pessoas dizem: do berço. Isso para mim que é educação quilombola, pode ser feito em qualquer outra comunidade desde que pertença àquele ninho, a vivência daquele povo. Nossa educação quilombola não foge a isso também.

Daí a relevância de refletirmos acerca da questão de Miguel Arroyo: "Mas o que aprender dos movimentos sociais no campo da pedagogia?" (ARROYO, 2012, p.25). O próprio autor tenta responder ao afirmar que: 
A resposta mais contundente é que os coletivos populares se reconhecem sujeitos de conhecimentos, de valores, culturas, sujeitos de processos de humanização/emancipação. Sujeitos pedagógicos produzindo Outras Pedagogias. (ARROYO, 2012, p.25).

É fundamental entender "a escola como um território de luta e que a pedagogia é uma forma de política cultural”. (GIROUX; SIMON, 2002, p. 93). Giroux e Simon chamam a atenção para a importância de se desenvolver uma pedagogia crítica "através das vozes e para as vozes daqueles que são quase sempre silenciados". (GIROUX; SIMON, 2002, p. 93). Os quilombolas estão propondo uma pedagogia ao lutarem por educação quilombola: "É nesse sentido que propor uma visão pedagógica é formular uma visão política”. (GIROUX; SIMON, 2002, p. 98). A Liderança B dá indícios da proposta pedagógica do movimento:

É apenas para o povo quilombola? Não acredito em uma educação escolar quilombola na qual ficamos segregados, onde a gente não consiga passar esses saberes. Para passar nossos pensamentos é preciso estar ali incluído, com outras pessoas, passando a nossa realidade e disseminando a nossa cultura. Uma educação escolar quilombola vai respeitar os saberes locais, pegar esse saber local e trazer para dentro das instituições de ensino. (...) A educação escolar quilombola, no caso da Áurea, tem que pegar os saberes da comunidade quilombola de Santa Rita do Bracuí, tanto as nossas práticas culturais, como nossas práticas de plantio e colheita, nossa história antiga e dessa vivência. O próprio representante, como militante quilombola, deve levar para dentro da escola como elemento interdisciplinar, pegar isso e transformar em uma forma em que todas as disciplinas, Matemática, Geografia, História e Ciências, consigam implementar essa educação em cima das nossas vivências, ou seja, estou ensinando a Matemática falando sobre a colheita da própria Jussara. Enfim, conseguir fazer com que o estudante se veja dentro da escola, como ele se vê na própria comunidade.

Educadora $\mathrm{A}^{36}$ ressalta a necessidade de inverter a lógica que impera nos espaços escolares: "Nós temos o costume de valorizar aquilo que o aluno aprende a partir da escola. Na educação escolar quilombola é preciso entender esse processo do que eles têm, seus saberes e conhecimentos precisam ser trabalhados". A pedagogia é compreendida por grupos mais conservadores como o meio de levar o "conhecimento" aos ignorantes, primitivos, etc. Os movimentos quilombolas afrontam tal lógica ao afirmarem serem capazes de produzir uma pedagogia em bases comunitárias, com seus valores, saberes, modos de pensar,

\footnotetext{
${ }^{36} 32$ anos, graduada em Música e Pedagogia, integrante da equipe pedagógica da Escola Áurea Pires da Gama desde 2010
} 
experiências, resistência etc. Em outras palavras, o movimento social vem disputando as concepções e as instituições que sustentam as pedagogias escolares dominantes:

Há um ponto que os coletivos populares em movimentos destacam ao afirmar-se sujeitos de processos pedagógicos: que na história foram vítimas de ocultamentos, inferiorizações até de sua sofrida história de afirmação de seus saberes, culturas, identidades. De suas pedagogias. Ignorar esses povos e suas pedagogias representa uma lacuna intencional nas narrativas da história das idéias de práticas pedagógicas. Qual a intenção dessa ignorância? Perpetuar uma das funções da autoidentidade das teorias pedagógicas hegemônicas: ignorar os saberes, valores, culturas, modos de pensar e de se afirmar e humanizar dos povos colonizados, dos trabalhadores para, reafirmar sua inferiorização, afirmar a função da pedagogia de trazê-los para a cultura e o conhecimento legítimos, para a civilização e a maioridade. Reconhecer que esses povos têm Outras Pedagogias produtoras de saberes, de modos de pensar, de se libertar e humanizar desestabilizaria a própria autoindentidade da pedagogia hegemônica. (ARROYO, 2012, p.30).

O movimento quilombola ao propor uma "Outra Pedagogia" se reconhece como sujeito pedagógico, pois percebe nas suas práticas cotidianas, enquanto movimento social e enquanto comunidade, elementos educativos que deveriam fazer parte do universo escolar: "A gente tenta trazer para dentro da escola esses saberes, tentando dialogar, tentando fazer com que todos respeitem, quebrando esse preconceito, discriminação que, por muitas vezes desconhecido, se torna um grande monstro" (Liderança C). Na tentativa de corrigir essas injustiças, o movimento negro quilombola propôs essa modalidade.

São duas coisas importantes, uma coisa é a modalidade, tem uma modalidade do que é educação escolar quilombola e tem uma lei que vai amparar essa modalidade. Então educação escolar quilombola não vai acontecer em qualquer escola. Ela vai acontecer em unidades específicas que estejam no território de Quilombo, que atendam os meninos e meninas que são quilombolas. Nesse sentido é que eu entendo que aqui é uma escola quilombola. Eu tenho um sonho, acho que a escola Áurea Pires vai ser um dia uma grande escola de referência, vai ser uma Escola de Formação. Tem outra coisa que acho importante dizer, tem a modalidade de educação escolar quilombola, só que a gente tem uma lei que é a 10.639 que depois virou 11 e alguma coisa, que coloca obrigatoriedade para dentro dos currículos desse estudo da história da África e da história dos nossos povos indígenas. Isso torna universal essa inclusão da discussão da escravidão no Brasil para a gente se constituir enquanto sociedade. Então não dá para dizer que só Áurea Pires tem que passar por esse processo. Todas as escolas precisam fazer a discussão da questão racial. Isso precisa integrar o currículo, esse é um grande desafio. Nesse sentido é que a nossa escola tinha que ser pioneira, tinha que ser um polo de formação, tinha que ser onde essas discussões deveriam irradiar, daqui. (Educadora B)

É interessante ter a compreensão que uma educação quilombola dialoga fortemente com a Lei 10.639/03, porém, tem uma responsabilidade ainda maior, 
pois deve atentar às especificidades locais da comunidade quilombola. Além disso, "não existe um formato para escola quilombola. Então a escola deve ser construída de acordo com a comunidade porque as comunidades são diferentes no Brasil e as escolas atendem públicos diferentes nas comunidades" (Educadora $\left.\mathrm{E}^{37}\right)$.

\title{
3.2 Desafios para uma Educação Quilombola na Escola Áurea Pires da Gama.
}

Os educadores e lideranças quilombolas, mesmo após a caracterização da Escola Áurea Pires da Gama como quilombola no Censo de 2015, mencionaram dificuldades para a efetivação de um Projeto Político Pedagógico adequado à realidade da comunidade quilombola de Santa Rita do Bracuí. Os depoimentos que serão apresentados contribuem para a reflexão acerca dos desafios para uma Educação quilombola, que se encaixa na mesma clave de uma Educação Diferenciada. A Educadora B exprime a seguir alguns desses desafios:

\begin{abstract}
Eu penso logo na questão estética, as pessoas precisam chegar aqui e ver que essa escola é diferente. Teria que ter outra estética, outra organização dos espaços, outras imagens. A gente precisava fazer essas modificações para dentro da questão do currículo. É claro que isso é muito difícil porque pra dentro do mesmo aparato que coloca uma lei que nos ajuda muito, que ampara a gente, ao mesmo tempo tem uma base curricular nacional. Isso é contraditório porque a educação quilombola e a educação indígena são afirmação da diferença. A educação do Campo, onde ela se encaixa, é afirmação da diferença, do peculiar, de trabalhar o único mesmo de acordo com o território. Mas se você tem uma base comum, como é que você faz isso? Você puxa para um lado e ao mesmo tempo puxa para o outro.
\end{abstract}

Se por um lado, a Educadora B aponta caminhos para pensar a efetivação de uma educação quilombola, em especial, no que tange à organização do espaço, por outro, ela também nos apresenta um paradoxo no tocante à legislação, que cria obstáculos para a efetivação de uma educação diferenciada. Se por um lado, o Governo Federal cria em 2012 as DCNs para uma educação quilombola, valorizando as diferenças sociais, em especial, dos negros. Por outro, o MEC (Ministério da Educação) publicou no dia 22 de dezembro de 2017 a Resolução $\mathrm{CNE} / \mathrm{CP} \mathrm{n}^{\circ} 2,{ }^{38}$ que estabelece e orienta a implementação da BNCC (Base

\footnotetext{
3737 anos, graduada em Língua Portuguesa, professora de Língua Portuguesa da Escola Áurea Pires da Gama desde 2012 e da Secretaria de Educação do Estado do Rio de Janeiro há 13 anos.

38 Disponível em: http://portal.mec.gov.br/conselho-nacional-de-educacao/base-nacional-comumcurricular-bncc. Acesso em:
} 
Nacional Comum Curricular), devendo ser aplicada nas diferentes modalidades da Educação Básica. ${ }^{39} \mathrm{O}$ MEC atual está indo na direção oposta a uma educação quilombola, indígena e do campo, pois uma Base Nacional Comum não valoriza o peculiar, o particular. Nesse sentido, se torna difícil romper com essa estrutura educacional que se consolida em governos conservadores. Essa política de uniformizar e/ou padronizar os espaços escolares também pode ser sentida nas esferas locais. No trecho a seguir, a Liderança A destaca a dificuldade de dialogar com a Secretaria Municipal de Educação de Angra dos Reis e com os educadores em função do universo escolar estar impregnado por um modelo tradicional que anula as diferenças, negando a urgência de uma educação que atenda às singularidades:

\begin{abstract}
O maior desafio é falar para a instituição educacional o que é essa educação quilombola. Para eles é uma coisa nova, então é difícil. O governo fala mais de diversidade. Dizem: educação quilombola é mais uma invenção do Povo. Então, o mais difícil é isso. As pessoas da Educação estão muito acostumadas com educação normal. Quando aparece algo novo, eles falam que é uma invenção, mas a educação quilombola sempre existiu do jeito que as pessoas contavam nas suas casas. O que queremos resgatar é essa educação quilombola, aquela da educação mais central, de dentro de casa, mais familiar, homenageando a comunidade toda. Mas como a gente depende de governantes, precisamos dançar conforme a música deles.
\end{abstract}

Daí a importância de termos espaços escolares diferenciados, que de fato consigam valorizar a história dos grupos historicamente marginalizados. E, dentre estes, os quilombolas. A diversidade deve ser trabalhada sempre nas escolas, porém, esse trabalho pode reforçar estereótipos por conta da história ser permeada pelo passado hegemônico de determinados grupos sociais. É importante assegurar que a diversidade apareça como garantia da atenção às especificidades. A Liderança A afirma que sempre houve uma educação não formal ou, como denomina, uma educação quilombola. Isso reforça a ideia de uma pedagogia que ocorre em outros espaços que não apenas os escolares. A Liderança B segue indicando como desafio o reconhecimento da escola como quilombola e a urgência de um PPP:

uma das maiores lutas, o maior desafio, foi o reconhecimento, de fato, da escola Áurea Pires como quilombola. Além de construir o Projeto Político Pedagógico

\footnotetext{
${ }^{39}$ Cabe ressaltar que a BNCC é aprovada pelo governo de Michel Temer que assumiu após o impeachment sofrido por Dilma Roussef, ato considerado por muitos grupos como um golpe contra a Democracia.
} 
que atenda a necessidade dessa escola quilombola, se tornando na prática. Ela está no território quilombola, mas ainda está engatinhando para que seja de fato uma escola quilombola. Nos moldes que ela está hoje nunca será quilombola, só conseguirá alcançar todas as nossas expectativas interagindo com a comunidade.

Embora a Escola Áurea Pires da Gama tenha sido caracterizada no Censo de 2015 como quilombola, não houve um reconhecimento por parte do governo na medida em que não foi publicado no BO (Boletim Oficial) da prefeitura de Angra dos Reis. Essa demora impede a escola de receber verbas do Governo Federal voltadas para uma educação quilombola. $\mathrm{O}$ depoimento a seguir enfatiza essa questão da ausência de um plano governamental para implementação das diretrizes:

Essa questão do plano de implementação das diretrizes, todas as instâncias têm obrigações: Estado, Governo Federal e Municípios. Principalmente, esse governo de agora questiona muito a gente em relação a sermos uma escola quilombola, mas eles não falam das obrigações enquanto governo municipal que não vêm sido cumpridas. Eles têm obrigação em relação a nossa formação diferenciada. Não estou criticando porque a coordenação fez aquele curso da plataforma, acho legal tem que ter mesmo, faz parte das obrigações, mas aquilo ali não dá conta para o grupo dos professores daqui que passaram por uma formação feita pelo quilombo. Não é mais aquilo, já teria que ter aqui um grupo apoiando de forma efetiva. Não é chegar aqui um dia e dizer as coisas, porque ninguém quer participar das nossas coordenações no "miudinho", encarar dificuldades com a gente para fazer isso. Então, o governo tem obrigação em relação a isso. A outra coisa que a gente pergunta e fica no impasse é esse reconhecimento oficial através do BO, para conseguirmos as verbas diferenciadas, poder participar dos editais diferenciados. Enfim, estão se amarrando em relação a isso. (Educadora B)

Esse não reconhecimento em $\mathrm{BO}$ pode ter duas explicações: ao se reconhecer a escola, o governo estaria reconhecendo a existência do território, a escola se tornou quilombola por conta de estar dentro de um território quilombola que está em disputa porque não houve ainda a titulação dessas terras; a outra seria o descaso com a modalidade, tendo em vista que implicaria maiores gastos e atenção por parte dos Governos. A Educadora A ressalta a falta de apoio do governo: "Nosso maior desafio é conseguir um apoio do governo, conseguir parcerias, porque ficamos muito sozinhos". A ausência de um projeto para a efetivação de uma Educação Quilombola pode ser percebida no fato da Secretaria não ter adotado, até então, a política de lotação, na escola, de educadores que se identifiquem com a modalidade de ensino. Isso aparece nos depoimentos de boa parte dos educadores: 
A lotação de todo mundo está aqui por qualquer motivo, menos porque é uma escola quilombola e eu quero trabalhar dessa forma. Isso, de certa forma, é um entrave também. As pessoas precisam saber que elas estão vindo para cá, tem que saber o que significa trabalhar com uma escola como essa. Elas precisam saber isso primeiro. Alguns vêm de fora, têm que ter essa clareza, eu acho que isso também é um desafio. As pessoas que trabalham aqui, a forma como lidam com os alunos, a relação que têm com essa discussão, não estou falando somente dos professores, porque em uma escola todos têm um papel educativo, todos sem exceção. (Educadora B)

Há uma rotação muito grande de educadores na escola, isso, de certa forma, está associado à falta de critério na lotação dos professores. Tal fato gera um problema porque nem todos os professores que estão na escola se identificam com o projeto de construir uma educação quilombola: "É uma luta muito nossa mesmo, às vezes acaba sendo a luta de grupos, temos o grupo do Quilombo que tem a luta deles, o grupo da escola que acredita e temos aqueles que não acreditam" (Educadora A). Uma participação do governo poderia ajudar a equalizar essas situações de conflito. Com base nos depoimentos, é possível perceber que o governo municipal não assumiu as suas responsabilidades colocadas pela DNCs para uma educação quilombola:

b) ofertar e executar a Educação Escolar Quilombola diretamente ou por meio do regime de colaboração com os Estados;

c) estruturar, nas Secretarias de Educação, instâncias administrativas de Educação Escolar Quilombola como a participação de quilombolas e de profissionais especializados de quilombolas e de profissionais especializados nas questões quilombolas, destinando-lhes recursos financeiros específicos para a execução das ações voltadas para a Educação Escolar Quilombola;

d) prover as escolas quilombolas e as escolas que atendem estudantes oriundos dos territórios quilombolas de recursos financeiros, técnicos, materiais e humanos visando, o pleno atendimento da Educação Básica (DCNs para a Educação Escolar Quilombola, 2012, Título VIII, Capítulo I, Artigo 58, p. 20).

É imprescindível para uma Educação de qualidade recursos materiais e humanos, em especial, quando se quer implantar uma escola diferenciada num bairro pobre com tantas demandas sociais que se estendem para dentro dos muros da escola. Outro desafio colocado pela Educadora $\mathrm{G}$, diz respeito à resistência que ocorre por parte dos educadores da escola:

O primeiro desafio é a resistência que não é no sentido quilombola, mas do corpo docente e dos funcionários da escola. Eu não sei como esse processo começou porque não acompanhei, quando cheguei esse processo já estava em curso há uns dois anos. Não sei como foi abordado e como foi instituído, se foi de cima para baixo, mas me parece que existe uma resistência muito grande porque tem especificidades no local. Há uma resistência em relação à própria educação 
quilombola que significa reconhecer a importância, a força do Quilombo e ter que repensar sua prática docente, que não é fácil. E uma resistência também de ver aquele espaço como quilombola. Então, tem esses dois processos tanto no que tange à própria atividade, o trabalho, à docência, e aí reconhecer a educação quilombola como importante.

O reconhecimento da escola como quilombola pelos educadores implicaria em repensar as práticas pedagógicas, tão enraizadas via formação ou prática docente. A Educadora $G$ segue explicitando outros possíveis motivos para essa resistência:

Não tenho dúvidas que seria o reflexo da sociedade e, exatamente, essa dificuldade que passa um pouco por essa ideia de que índio não pode usar calça jeans. É um pouco assim, se o território não é completamente rural, senão é extremamente negro em relação a todas as pessoas que o formam, se não estão dançando qualquer coisa relacionada ao Jongo, então não seria um quilombo. Acho que as pessoas têm muita dificuldade em entender. De um lado estão às pessoas relacionadas ao quilombo que queriam que ela fosse uma ferramenta política de reafirmação do Quilombo e de sua importância e, do outro, outras pessoas não queriam ou não enxergavam a escola como quilombola. Inclusive, há um discurso afirmando que isso minaria as outras manifestações culturais que compõem a escola.

Os motivos, segundo a Educadora G, à negação da comunidade como quilombola passa por uma ideia preconceituosa, ou seja, por uma cristalização dos povos tradicionais que impede alguns indivíduos de perceberem aquelas pessoas (quilombolas) ou aquele espaço como pertencente a uma comunidade tradicional. Além disso, há por parte de alguns professores uma resistência alicerçada na ideia de que uma escola quilombola excluiria as manifestações culturais dos alunos não quilombolas. Essa preocupação mostra um desconhecimento em relação às diretrizes quilombolas, já que elas partem do pressuposto que se faz necessário afirmar a diferença cultural e construir uma Educação Pluricultural.

Há uma visão distorcida e preconceituosa, acerca do que seriam as comunidades tradicionais, que atrapalham a construção de uma educação que acolha e valorize a diferença. Como exemplo, podemos citar a essencialização da cultura indígena, inclusive, no espaço escolar. Cabe lembrar da representação pretérita feita nas escolas no dia do Índio. Da mesma forma, como visto na discussão do Capítulo I sobre o conceito de quilombo, os quilombos são associados aos acampamentos militares do período da escravidão. Em alguns casos, há o reconhecimento da comunidade como quilombola, porém, se saírem da imaginada "cartilha" das práticas tradicionais, logo são taxados como não quilombolas, como se houvesse uma cultura petrificada ou pura. Esse mesmo 
argumento é usado para negar direitos, dentre os quais, estão o direito a uma educação quilombola e à titulação de suas terras.

A seguir, destaca-se outro episódio que ilustra a resistência, por parte de alguns educadores da Escola Áurea Pires, no final do ano de 2015, quando da realização de uma reunião entre corpo docente, direção, Secretaria de Educação e algumas lideranças quilombolas para a tomada de decisão acerca da entrada da escola no Censo como escola quilombola.

Teve gente que discordou na reunião que a escola virasse quilombola porque achou que os quilombolas iam adentrar na escola, mandar na escola e mudar tudo. Aí falamos que não era bem assim: - Nós estamos em 2015, calma!

Tinha esse medo até na cabeça dos professores:

- Vai mudar alguma coisa?

- Vai, é lógico! Isso está nas diretrizes de uma educação quilombola!

- Mas não vai haver uma mudança drástica?

- Vai quase que continuar sendo uma escola normal, até porque não tem só quilombolas aqui, tem outras pessoas também!

Não é essa mudança radical como o pessoal achava. Os professores também têm a mesma confusão na cabeça. (Liderança A).

A Educadora $\mathrm{F}^{40}$ afirma que houve um erro no processo de discussão da entrada da escola no Censo de 2015 que levou os educadores a terem dificuldade em compreender o que significava vir a ser uma escola quilombola:

Eu avalio que não houve discussão. Os encontros vinham acontecendo e quando se aproximou do censo, marcaram uma reunião para discutir com a presença da secretária. Eu acho que foi uma forçação [sic], eu, por exemplo, não votei, não quis votar, não acreditei naquele processo. Aquela discussão estava muito rasa para decidir aquilo de forma tão rápida. (...) Eu não vi resistência por parte dos colegas para que escola se tornasse quilombola. As pessoas discutiram e votaram, praticamente, foi unanimidade. Não houve resistência na votação, mas havia uma resistência no sentido do entendimento, ou seja, faltou discutir. Não vi ninguém afirmando que a escola não deveria ser quilombola, só achavam que deveria haver mais discussão.

O Educador D também parte do pressuposto de que a resistência não era em relação a se classificar como quilombola, mas do que isso significava para a comunidade e quais as suas implicações no cotidiano escolar, nos seus trabalhos. Além disso, os educadores apontam que haveria necessidade de uma discussão por um tempo maior, com o envolvimento de toda a comunidade escolar:

${ }^{40} 37$ anos, graduada em Artes Visuais, professora de Artes da Escola Áurea Pires da Gama e da Secretaria do Estado do Rio de Janeiro desde 2009. 
Acho que a discussão foi falha, porque nem todo mundo participou e não, necessariamente, quem participou estava inteirado do assunto, tanto os funcionários da escola, quanto os alunos, que não foram consultados, quanto a comunidade. Era interesse de quem que a escola virasse quilombola? A reunião estava esvaziada se compararmos com quantidade de funcionários da escola. Foi uma discussão de um dia, não foi um debate aprofundado, foi uma discussão de um dia com aceita ou não aceita. Então, foi uma decisão tomada no susto, sem discussão, sem aprofundamento e reflexão. Eu acho que deveria ter havido discussão para decidir. A resistência aconteceu por causa do desconhecimento e do que significa para comunidade. Segundo, é não saber como lidar com o assunto, muito da resistência vem do: E agora o que eu vou fazer?

Já nas palavras do Educador $\mathrm{C},{ }^{41}$ nota-se uma defesa da ideia da escola não se tornar quilombola:

Primeiro, eu acho que não precisava colocar a escola Áurea Pires como escola quilombola, sem esse status de quilombola. Mas poderia ser um grande centro de estudos. A Cândido Mendes fez um Centro de Estudos Afro-Asiáticos, ela não virou uma Universidade Quilombola. Quando você coloca a escola como quilombola, você vai ter que dar mais ênfase no currículo e cultura quilombola. Eu me pergunto até que ponto não estamos deixando de ampliar o horizonte de nossos alunos. Será que não vamos negar aos alunos o acesso a um concurso público? Eu acho que não deveria se tornar uma escola quilombola, mas um excelente Centro de Estudos, um grêmio ou grupo de estudos para que as pessoas conheçam a sua cultura, valorizar, mas, também saibam que o mundo não é só o Quilombo do Bracuí, tem ENEM e concurso público... Mas, eu sou aberto, se conseguir me convencer dentro de um argumento plausível, ganharão mais um aliado.

Há entre os educadores contemporâneos uma preocupação muito grande em permitir aos alunos o acesso a conteúdos do currículo prescritivo para participarem de processos seletivos em Universidades e/ou concursos. Isso tem dificultado a implementação de uma educação quilombola, já que essa exige o fim dessa centralidade dos currículos prescritivos. O depoimento do Educador D exprime um pouco a complexidade para se construir uma educação quilombola:

O Primeiro desafio é que não tem um modelo, você cria no fazer. Isso é complicado, principalmente quando se encontra resistência de algumas pessoas que não querem participar do processo. Uma parte é da secretaria, a outra são educadores e a própria comunidade - pessoas que não querem ser reconhecidas como quilombolas. Isso se deve ao preconceito que existe com essa nomenclatura do que acarreta ser quilombola. Quanto aos profissionais, o problema é a novidade, não conhecer: como sair do tradicional que você já está acostumado, falar de uma coisa que você vai ter o trabalho de aprender. Então tem um comodismo misturado com medo. A secretaria não reconhece as individualidades. Ela quer tratar todas as escolas como um padrão, não reconhece a autonomia da Unidade Escolar.

\footnotetext{
${ }^{41} 48$ anos, graduado em História e pós-graduação (lato sensu) em História da África, professor de História da prefeitura do Rio de Janeiro há 15 anos e professor de História na Escola Áurea Pires da Gama há 12 anos.
} 
Mesmo com as DCNs quilombolas, é possível perceber que os professores não se sentem seguros, não sabem se suas práticas condizem ou não com uma Escola Quilombola. Por isso, parte dos educadores da Escola Áurea Pires da Gama coloca a falta da formação como um dos desafios para se construir uma Educação Escolar Quilombola: “O primeiro desafio é o meu conhecimento sobre o assunto". (Educadora F). O movimento quilombola de Santa Rita do Bracuí, percebendo essa dificuldade dos educadores, propôs o curso de formação já mencionado anteriormente. Cabe enfatizar que nessa época a escola ainda não havia sido caracterizada no Censo como quilombola, além disso, muitos educadores sequer sabiam que a escola poderia se tornar uma escola quilombola, assim como desconheciam o fato da escola estar dentro do território quilombola. Nos trechos das entrevistas, a seguir, serão explicitadas impressões dos educadores e lideranças do como se deu esse processo de formação na Escola Áurea Pires da Gama, assim como ajuda a pensar sobre o futuro desse processo de formação na escola, abrindo caminhos para refletir acerca de futuras formações no campo da educação diferenciada, em especial, quilombola.

A Liderança $\mathrm{C}$ nos explica a seguir como o movimento quilombola teve a ideia de propor um curso de formação na Escola Áurea Pires da Gama logo após alguns jovens quilombolas se formarem em Educação do Campo pela Universidade Federal Rural do Rio de Janeiro:

Quando nos formamos pensamos que retorno daríamos para comunidade. A gente não quer só guardar e colocar o diploma na parede. Conversando com uma liderança, chegamos à conclusão que a Áurea Pires já teve tanta coisa bonita, a Feira Frutos da Terra, que permanece até hoje, é uma delas. A gente pensou em fazer algumas oficinas, a princípio. Pensamos em fazer sobre a história do Quilombo, sobre o palmito Jussara e o Jongo. Levamos essa proposta para a escola, quando nós fizemos a reunião, depois de nos formarmos no dia 14 de setembro de 2013 na graduação. Fomos até a escola com a AQUISABRA ${ }^{42}$ propor essas oficinas. Nós pedimos ajuda para a Marília (professora da UFRRJ) porque era época do concurso em Angra. Aí ela foi conosco conversar com a Secretaria. O objetivo era animar os professores, já que tinham professores que levavam suas turmas no quilombo. Então, a Marília propôs fazer um projeto de extensão. Fomos à escola no dia 24 de setembro de 2013 para fazer a primeira reunião com a direção. Depois, tivemos a ideia de fazer um fórum com o nome Redescobrindo o Bracuí. Fizemos um fórum com direito a uma feijoada do EJA. Foi muito boa a participação de todos. Foi quando começou a formação de 180 horas em parceria com a Universidade. Foi na cara e na coragem, sem nenhuma ajuda ou incentivo.

\footnotetext{
${ }^{42}$ Associação Quilombola de Santa Rita do Bracuí.
} 
A escolha do espaço da escolar da Áurea Pires da Gama como campo de atuação da militância demonstra o quanto é significativa uma educação diferenciada para a comunidade. É importante destacar a coragem desses jovens que não tiveram nenhuma ajuda financeira do governo municipal para darem um passo tão importante rumo a uma Educação diferenciada. Uma experiência nova, já que nunca haviam participado de algo desse tipo. No trecho a seguir, a Liderança B relata um pouco dessa experiência:

Acho que foi um curso muito rico, de experiência para gente, principalmente, para o pessoal que estava fazendo licenciatura no campo. Foi um aprendizado, porque não sabemos tudo sobre a comunidade, vamos nos formando ao longo dessa vivência. Nós sempre estamos aprendendo alguma coisa, conversando, informalmente, na casa dos mais velhos. Nos cursos que participamos, sempre levamos coisas ou trazemos, como, por exemplo, o mapa falado que se chama Passado Presente e Futuro. Aprendi semana passada sobre o galpão, há um tempo, não tinha essa informação. $\mathrm{O}$ curso de formação trouxe um aprendizado muito grande para nós. Serviu, inclusive, para percebermos até onde podemos chegar na escola Áurea Pires da Gama e até onde, de fato, acreditamos nessa educação quilombola que está sendo implementada ali pela escola. (...) $\mathrm{O}$ curso de formação, como espaço, teve limitações, mas foi um espaço super válido, até para nossa formação política. Se hoje estou falando de educação quilombola é graças àquele momento de formação, antes eu não tinha conhecimento sobre escola quilombola e hoje em dia até já falo nos meus trabalhos da faculdade sobre educação quilombola.

É importante ressaltar essa perspectiva da Liderança B de que vamos sendo formados ao longo das nossas experiências. A construção de uma educação quilombola pressupõe um processo permanente, as trocas contínuas entre comunidade e escola irão dar forma as práticas escolares de uma educação quilombola. Essa troca de experiência no curso permitiu o debate não apenas acerca da história local, mas de se pensar uma escola diferenciada, na construção de uma escola quilombola. Nas palavras da Liderança C: "O que a gente queria mesmo era plantar uma sementinha, por mais que a terra seja grande para gerar frutos lá na frente". Segue a avaliação da Educadora E sobre o curso de formação:

Percebo que durante o curso comecei a me policiar mais. Inconscientemente, vamos mudando o nosso modo de trabalhar. Achei isso muito positivo, porque mudou não só a minha postura na escola, mas, também, a minha postura como professora do ensino médio na rede estadual. (...) Todos nós mudamos, amadurecemos em relação à questão do preconceito, a demonização das religiões de matrizes africanas.

Daí a importância das DCNs quilombolas e da Lei 10.639, serem seguidas por políticas de formação continuada. No caso da Escola Áurea Pires da Gama 
foram os quilombolas que ofereceram uma formação, mesmo com todas as suas dificuldades, cumpriram um papel que, por lei, não seria deles. A Educadora B segue apontando algumas reflexões que julga importantes para se pensar em formação continuada para uma educação quilombola:

Tem outra coisa que tem me incomodado muito ultimamente, a formação. Para formar um bom profissional se pensa a questão técnica do estudo, mas não tem uma questão de sensibilidade. Como se forma as pessoas para essa sensibilidade? Isso eu não sei. Alguma coisa tem a ver com aquilo que a pessoa é. Tem um autor português, o Antônio Nóvoa, que diz que o professor é a pessoa e a pessoa é o professor. Então, tem a ver com nossas histórias, com a nossa trajetória, com a nossa experiência de vida. $\mathrm{O}$ contexto de formação não é apenas a formação acadêmica, são os espaços religiosos que a gente frequenta, é a nossa família, é o lugar onde a gente nasceu e cresceu, é a classe social a qual a gente pertence, se identifica ou de origem. Tudo isso faz parte dessa complexidade da questão da formação. Então, na minha cabeça tem muitos problemas, tem muitas perguntas sobre formação que vão se desenhando. (...) Em termo de formação continuada para quem já está na escola, não tem como não pensar em formação sem pensar em respeito às pessoas que estão na escola, respeito ao espaço físico e dessas pessoas, dignidade para as pessoas que estão aqui. Acho que para transformar a escola em um espaço de formação, precisamos começar a trabalhar os espaços da comunidade como espaço para nossa formação e assumir o nosso papel de produção intelectual porque a nossa tarefa é intelectual. (...) quanto mais a gente valoriza aquele espaço de coordenação, como espaço de produção intelectual militante, isso nos torna mais fortes, nos valoriza enquanto categoria, enquanto escola.

Uma formação talvez não preencha todos os requisitos para ser professor de uma escola quilombola. Os educadores precisam se identificar com a modalidade de educação quilombola e, assim, se engajarem nesse processo de construção. Além disso, como mencionou a Educadora $\mathrm{B}$, os educadores precisam se compreender como produtores intelectuais, pois, exercem uma atividade intelectual de produção de conhecimento, o escolar. Não são apenas mediadores ou reprodutores de uma cultura escolar. Uma educação quilombola, por ser específica, exige ainda mais dessa autoria dos educadores junto com a comunidade quilombola. A Educadora G não participou do curso de formação por ter entrado na escola depois, porém defende uma formação que deve ser realizada no cotidiano escolar: "A formação deve se fazer no dia a dia escolar, com os professores tendo mais abertura. Eu não tive a experiência mais formal sobre educação quilombola. Hoje eu diria que seria mais no dia a dia, de estar experimentando outras formas de fazer educação, mais ligado à realidade quilombola que de fato não acontece". Antônio Nóvoa (2011) destaca a importância de uma formação que seja feita na escola pelos próprios educadores 
escolares, pois são eles, junto com a comunidade escolar, os mais capazes ou únicos para identificarem demandas na escola para um processo de formação. Além disso, a Educadora B adverte os educadores para o fato da ausência de políticas de formação continuada ser, provavelmente, uma estratégia dos governos:

Sempre quando se quer apontar qualquer dificuldade, qualquer falha se bate na tecla da formação, o problema é a formação, consequentemente, o problema são os professores. Então, se busca um bode expiatório e são sempre os professores. Quem aponta o dedo para os professores e diz que o problema é a formação é o próprio Governo Federal, o mesmo que certifica os cursos de formação dos professores e que autoriza o MEC a certificar os cursos onde os professores são formados, isso quando oferece cursos. Esse discurso da formação, às vezes, pode ter uma armadilha para jogar para cima dos professores, é claro que as graduações são muito deficitárias, ainda são disciplinas optativas que tratam de questões específicas em relação à questão racial, o que vai dificultar muito depois para a gente como profissional dentro da escola.

Ainda falando do curso de formação, alguns educadores criticaram a forma como foi conduzindo:

Acho que a ideia foi muito boa, mas eu senti falta de que aqueles encontros tivessem um formato de aula. Aula no sentido tradicional, de professora que vai falar e o aluno que vai ouvir. No início desse curso - estou falando do formato que também tem relação com os conteúdos - houve alguns encontros com aulas, os meninos estavam na Rural trazendo muitas informações. Depois, havia momentos em que os professores se reuniam para decidirem ações ou retomarem ações que já tinham sido feitas. Após esse primeiro momento, o restante não foi produtivo porque ficou faltando mais, cadê as informações que eu não tenho? Na formação você precisa primeiro sentar e ouvir. Você não começa logo dissertando, você primeiro ouve e lê sobre o assunto. Daí você já terá uma base de onde partir, podendo explorar mais, você tem referência, informação. Isso me faltou aqui. Como falei antes, o primeiro desafio é o conhecimento e o curso não supriu isso. Nós tínhamos aqui bons professores que poderiam ter feito isso de forma excelente, mas não aconteceu, provavelmente, porque eles quiseram um formato diferente para o nosso curso, de uma forma que julgavam mais dinâmica. Acho que esse caráter dinâmico não funcionou. Eu queria uma coisa mais tradicional, queria aula, estudar igual na graduação. (Educadora F)

Parte dos educadores criticou o curso de formação por não ter um programa, por não haver uma ementa, uma bibliografia, ou seja, por não ter um formato tradicional. Os educadores, assim como os alunos, estão embebidos por esse modelo de formação tradicional. Talvez, pensar um novo modelo de educação implique repensar a própria formação. A Educadora A participou da organização da formação e expõe a seguir o objetivo pretendido do curso de formação e algumas dificuldades: 
A proposta era trazer essa formação do que é, do que a gente quer, trazer o entendimento para o grupo. A proposta inicial era que todos participassem, não só os professores, porque queríamos que todos compreendessem. Só que isso foi se perdendo ao longo do caminho, eu não sei se foi a falta de organização - não saberia como explicar - ou de um projeto de curso porque em 2014 aconteceu legal. A partir daí, de 2015, começou a se perder, tivemos greves, professores contratados que saíram e não conseguimos dar uma continuidade. A Universidade deveria ter se organizado mais, não digo as meninas do quilombo, nem digo as professoras que vinham aqui por conta própria, já que não havia investimento nenhum, gastavam o dinheiro delas e a escola ajudava como podia, mas precisavam de uma organização, como, por exemplo, o material para ler, material didático e várias outras coisas que precisávamos e não aconteceu.

A falta de recursos impediu a produção de materiais, de convidar outros palestrantes, de fazer encontros em outros espaços e outras tantas coisas que uma formação demanda. O apoio da Secretaria de Educação se resumiu a autorizar a formação, não houve aporte financeiro ou material. Essa falta de apoio explica um dos desafios que seria produzir materiais didáticos que pudessem servir de apoio para os professores em suas aulas. A Liderança C enfatiza a importância de materiais específicos para uma escola cuja rotatividade de professores é muito grande:

O desafio, também, foi encontrar material didático, livros que falem da temática. Um material que servisse de apoio para tratar sobre a questão do cabelo, que ajudasse as crianças. (...) Seria bom se conseguíssemos livros para tratar da cor da pele, sobre o racismo, sobre quilombo para que os professores tenham material didático. (...) Se mantessem [sic] a equipe seria legal, os que estão chegando não terão a mesma formação, não tem como fazer a toda hora uma formação. Mas se tivéssemos o material de apoio, ficaria melhor.

Ainda sobre a formação, a Liderança A mencionou o fato dos professores reclamarem do curso ter sido repetitivo. Entretanto, afirmou que faz parte da cultura oral da comunidade quilombola. Ou seja, é de tanto contar e recontar que os indivíduos acabam se educando.

Outra questão que se impõe é como a comunidade irá lidar com o fato da escola se tornar quilombola. A Educadora $G$ afirma que não foi colocada essa discussão de forma ampliada: "Nós nem chegamos a levar essa discussão para a comunidade escolar". Uma questão delicada, pois dentro da própria comunidade de remanescentes de escravizados há membros que não se identificam como quilombolas. A Educadora $\mathrm{F}$ expõe o preconceito racial como um fator de dificuldade à construção de uma educação quilombola: 
Sacaneiam uns aos outros com essa questão, debocham uns dos outros por serem quilombolas, talvez, porque achem o nome engraçado, sem nem saber o que significa. Afirmam que fulano mora lá longe, lá no quilombo, como se a escola já não estivesse no Quilombo. É um grande desafio a brincadeira que os alunos têm uns com os outros, de forma preconceituosa, que tem relação com a forma como eles próprios se enxergam, brincam chamando o outro de macaco, preto, seu isso, seu aquilo. Entender isso como brincadeira, é um problema. Por que debochar do outro com essas questões? Por que isso é engraçado? Acho que reverter tudo isso é um desafio muito grande.

O preconceito quando instalado na educação é muito mais perigoso na medida em que a escola é um dos principais instrumentos de formação dos indivíduos. A escola deveria ser o espaço de acolher as diferenças e valorizá-las, não deveria ser utilizada para manter os preconceitos. Contudo, a escola de hoje não está fora de uma sociedade racista, e, assim, ela também reproduz preconceitos. Daí a importância da escola estar a serviço do respeito à alteridade e da afirmação da diferença.

Ao longo da nossa história houve uma desvalorização da cultura de origem africana, o preconceito maior está em relação a isso. A sociedade só vê a questão do negro chegando como escravo, não olha para o todo, como o enriquecimento cultural. Tentam, ao longo da história, justificar a escravidão desmerecendo toda sua cultura, como a questão religiosa. Tudo isso alimenta o preconceito. Há uma demonização das culturas africanas, como consequência disso nós vemos o preconceito, acabamos não conhecendo e o desconhecimento leva ao preconceito. Romper esses paradigmas é muito difícil porque está enraizado dentro da gente, de nós mesmos, professores. Às vezes nós temos um pensamento preconceituoso, mas já temos uma autocrítica, pensa e se corrige, imagine a população em geral. (Educadora E)

Uma violência que está intrínseca nas práticas de sala de aula e na sociedade em geral, um racismo velado e, por isso, muito mais danoso por se camuflar na ideia de que somos todos iguais. Esse racismo se revela como uma dificuldade para a implementação de uma educação quilombola. Uma das formas mais violentas desse racismo pode ser percebida no preconceito com as religiões de matriz africana. O Educador C coloca, inclusive, esse preconceito como uma das dificuldades para uma educação quilombola:

Uma das dificuldades que já vi numa escola de outra prefeitura, e que pode acontecer aqui, é o advento das novas religiões evangélicas que vão assumindo esses espaços e se agarrando em uma espécie de preconceito. Por exemplo, quando você vai falar sobre História da África, uma lei que eu acho que foi sancionada em 2003, a lei 10.639, você encontra pais que se recusam que se fale dos orixás. Então, esse embate é o maior risco. 
O processo de marginalização das manifestações culturais de matrizes africanas, em especial as religiões, vem dificultando o desenvolvimento desses conteúdos nas salas de aula. A resistência parte do pressuposto de que esses conteúdos ferem a liberdade religiosa. Entretanto, essa justificativa esconde em seu cerne o preconceito racial, este, envelopado na acusação de proselitismo. No caso do Bracuí, parte dos moradores do bairro e dos alunos associa o Jongo às religiões de matrizes africanas, independente, se os jongueiros afirmam serem de variadas religiões, inclusive, cristã.

Alguns professores reforçam o racismo quando não tratam de tais temáticas nas escolas e, também, quando abordam esporadicamente nas escolas ou de forma rasa. Nesse sentido, Pereira e Roza chamam a atenção para os riscos de um tratamento não adequado das temáticas: "Tais riscos explicitam-se em perspectivas focalizadas na folclorização, superficialidade, banalidades, exotismo, alegorização e estereotipagem, tornando-se assim problemática a visibilização, assim como seu oposto". (PEREIRA e ROZA, p. 94, 2012).

O movimento quilombola de Santa Rita do Bracuí, percebendo essa necessidade, vem exigindo uma educação diferenciada, compreendendo que essa seria a forma mais apropriada para sua realidade de quilombola e negro. $\mathrm{Na}$ tentativa de construir essa educação, a Liderança B indica caminhos para lidar com as resistências, chamando a atenção para a necessidade de um trabalho pedagógico com toda a comunidade escolar, ensinado o que significa uma educação quilombola. Dessa forma seria possível ressignificar o conhecimento sobre o assunto e, talvez, um engajamento na causa por uma educação quilombola:

A resistência ela vai existir para tudo aquilo que é pautado pela minoria. Ela também existe pelo fato de sermos criados para não aceitar o diferente. Somos criados para seguirmos um padrão, esse estranhamento no começo é algo natural. Quando começou essa discussão de quilombo aqui na comunidade havia grande estranhamento, as pessoas diziam que além de serem pretas ainda tinham que se reconhecerem como quilombolas. Depois, as pessoas sabendo o que é, tendo acesso à informação, tenderam a mudar as suas opiniões, a reinventar o pensamento, ressignificar. Obviamente, tem aquelas pessoas que não mudam. 


\subsection{Urgência de um Currículo Diferenciado}

O movimento quilombola, ao indicar nas DCNs quilombolas a urgência de um currículo diferenciado, está propondo repensar uma nova epistemologia educacional, pois compreende que apenas uma nova epistemologia poderá reparar desigualdades sofridas por negros e quilombolas. Santos (2010) chama atenção para o fato de essas desigualdades estarem ancoradas no pensamento moderno ocidental, denominada pelo autor de Epistemologia do Norte ou de Pensamento Abissal. O Pensamento Abissal é, segundo o autor, um sistema de distinções visíveis e invisíveis que atravessam todo o tecido social.

As distinções invisíveis são estabelecidas através de linhas radicais que dividem a realidade social em dois universos distintos: o universo 'deste lado da linha' e o universo 'do outro lado da linha'. A divisão é tal que o 'o outro lado da linha' desaparece enquanto realidade, torna-se inexistente, e é mesmo produzido como inexistente. Inexistência significa não existir sob qualquer forma de ser relevante ou compreensível. (SANTOS, 2010, p. 32)

Santos sugere a construção de uma epistemologia do Sul, ou seja, de um pensamento pós-abissal que estaria alicerçado em uma "ecologia de saberes". O objetivo principal seria superar essas desigualdades históricas. É impossível construir uma sociedade menos desigual sem uma epistemologia que se contraponha a esse pensamento hegemônico, monolítico e excludente. A construção de uma epistemologia do Sul se faz necessária para desnaturalizar, descortinar, possibilitar ver como há uma cortina de fumaça que nos impede de enxergar o que sustenta nossos problemas sociais, como a questão do racismo, homofobia, xenofobia e outras tantas formas de exclusão.

Confronta a monocultura da ciência moderna com uma ecologia de saberes. É uma ecologia, porque se baseia no reconhecimento da pluralidade de conhecimentos heterogêneos (sendo um deles a ciência moderna) e em interações sustentáveis e dinâmicas entre eles sem comprometer a sua autonomia. A ecologia de saberes baseia-se na ideia de que o conhecimento é interconhecimento. (SANTOS, 2010, p. 53)

Esse processo de desconstrução e construção não seria possível sem uma reflexão do papel que a educação escolar ocupa. Seja para uma educação emancipatória, como uma ecologia de saberes, onde os conhecimentos dos grupos são apresentados em uma perspectiva horizontal ou, como se apresenta hoje, segundo alguns estudos, negando as diferenças, afirmando uma visão monolítica de sociedade na qual só é possível viver dentro desse modelo capitalista. O 
movimento quilombola, no geral, e do Bracuí, em específico, vão na direção dessa epistemologia do Sul ao proporem um currículo para uma educação quilombola que valorize as diferenças, pois pensar as especificidades de forma horizontal é ir na direção de uma ecologia de saberes. O currículo quilombola deve ter como um dos horizontes a construção de uma ecologia de saberes, uma construção coletiva, por isso, horizontal. Nesse sentido, o diálogo com educadores e lideranças do movimento quilombola do Bracuí corrobora para adensar o debate acerca dos currículos escolares.

No início de 2016, após o curso de formação e da escola ter sido caracterizada como quilombola no Censo escolar de 2015, houve um encontro na Escola Áurea Pires da Gama com o objetivo de começar uma discussão e elaboração de um currículo diferenciado, porém, não houve continuidade. A Educadora $\mathrm{G}$ apresenta como se deu a proposta de encaminhamento desse encontro:

\begin{abstract}
A única coisa que eu participei foi uma espécie de oficina mediada por professoras que tentaram, com a ajuda de pedagogas da escola, a partir de eixos, integrando grandes linguagens, história e geografia, português e artes, matemática e ciências, enfim, tentaram pensar a partir desses grandes eixos um currículo diferenciado. (...) Quem participou tentou avançar de alguma forma, mas o resultado foi nulo. Eu não diria que tenho experiência na construção de um currículo diferenciado para uma escola quilombola, o avanço foi muito pouco e acho que o trabalho deveria ser de uma forma constante e sistemática e, tenho certeza, exigiria muito da gente.
\end{abstract}

A Educadora $G$ está correta ao afirmar que a construção de um currículo para uma Educação Quilombola exigiria muito dos envolvidos no processo. O autor Michel W. Apple (2002) coloca que a escolha de conhecimentos a serem ensinados está para além de uma questão meramente educacional ou curricular, mas se trata de um assunto ideológico e político. Segue afirmando que o “currículo e as questões educacionais mais genéricas sempre estiveram atrelados à história dos conflitos de classe, raça, sexo e religião, tanto nos Estados Unidos quanto em outros países" (APPLE, 2002, p. 39). Sendo assim, é de suma importância e urgência a discussão sobre currículo. Sobretudo, quando se trata de um currículo quilombola, envolto em tantas demandas de uma população historicamente subtraída de seus direitos básicos de cidadania, dentre os quais o direito à terra, educação, a uma memória social, ao respeito, à dignidade, à moradia, à saúde e outros tantos direitos. O currículo não é apenas território de 
conteúdos. Portanto, o currículo para uma educação quilombola pressupõe pensar a:

Organização dos tempos e espaços escolares de suas atividades pedagógicas, das interações do ambiente educacional com a sociedade, das relações de poder presentes no fazer educativo e nas formas de conceber e construir conhecimentos escolares, constituindo parte importante dos processos sociopolíticos e culturais de construção de identidades. (DCNs para Educação Escolar Quilombola, art. 34, p. 13, ano 2012)

Essas questões são de suma importância para compreendermos o currículo para além dos conteúdos e refletirmos acerca da urgência de currículos diferenciados, em especial, o quilombola. Isto posto, seguem as impressões do Educador D sobre a discussão de currículo diferenciado na Escola Áurea Pires da Gama:

Como a gente também não teve fundamentos sobre currículo, acabamos discutindo com base naquilo que nós conhecemos que é o currículo tradicional. Então, acho que o quilombola acabou não entrando naquele currículo que estava construindo. Deveria ter mais preparação. Nós falamos no curso de formação das leis, apesar de não ter pegado as leis para destrinchar, e da questão histórica, mas faltou o que os quilombolas querem dessa educação escolar, porque se ouviu muito a parte dos educadores, mas e o que os quilombolas querem? Porque senão, a gente estará fazendo por eles. Mas e a participação deles?

O depoimento do Educador D converge com as DCNs quilombolas: "Os Currículos da Educação Básica na Educação Escolar Quilombola devem ser construídos a partir dos valores e interesses das comunidades quilombolas em relação ao seu projeto de sociedade e de escola, definidos nos projetos políticopedagógico" (DCNs para Educação Escolar Quilombola, 2012, art. 34, p. 13). A Educadora B expõe as dificuldades de se colocar essas discussões para dentro do currículo:

Eu acho que a gente não conseguiu caminhar para fazer essas inserções no currículo, fazer essas modificações. Vários fatores contribuíram para que isso acontecesse, vários atravessamentos naquele período de tempo: greve, falta de pagamento de salário, várias coisas aconteceram que acabaram desmobilizando a discussão. Outra coisa diz respeito ao atravessamento das relações pessoais. Com o tempo fui percebendo que existia uma insatisfação no grupo em relação àquela formação, em relação como o processo estava acontecendo. Então, acho que essas questões atravancavam as coisas.

É importante fazer um planejamento para prevenir situações que são corriqueiras na educação pública, pois a desmobilização em torno de temas tão caros, como o currículo, são uma constante. Além disso, é importante elaborar 
estratégias que envolvam os educadores e a comunidade escolar nessa empreitada curricular, antes mesmo de propor um currículo quilombola. A mesma entrevistada ratifica o enraizamento dos currículos tradicionais como sendo algo que também atravanca a discussão de currículos diferenciados:

Ao mesmo tempo também é uma discussão muito difícil de fazer. Pensemos em mim, depois dos 3 anos de idade eu nunca saí da escola, primeiro como aluna e depois como professora. Acho que a única profissão que a gente aprende a ser profissional desde que entra na escola. Então a gente aprende o que é ser professor dentro daquele modelo desde os 6 anos, em média. Isso está muito enraizado na gente. Então, fazer a discussão curricular é mexer em questões que estão muito cristalizadas nas disciplinas de História, Matemática, Português, etc. Tem questões que as pessoas defendem porque tem convicções, acreditam que aquilo é imprescindível para os alunos aprenderem, a discussão de currículo é mexer em um território complicado. (Educadora B)

Os educadores devem compreender o currículo como um território em disputa, ou seja, o currículo personifica projetos sociais em disputa. Os currículos são parte de uma engrenagem social, marcada por escolhas que legitimam determinados conhecimentos e relações de poder. A seleção de determinados conhecimentos em detrimentos de outros é um ato de poder:

O currículo não é um elemento inocente e neutro de transmissão desinteressada do conhecimento social. O currículo está implicado em relações de poder, o currículo transmite visões sociais particulares e interessadas, o currículo produz identidades individuais e sociais particulares. O currículo não é um elemento transcendente e atemporal - ele tem uma história, vinculada a formas específicas e contingentes de organização da sociedade e da educação. (MOREIRA E SILVA, 2002, p. 8)

Compreender as tensões imbricadas no currículo é fundamental para se pensar acerca da relevância de construir um currículo quilombola em outros moldes. Definir um tipo de identidade ou subjetividade também é uma ação de poder. (SILVA, 2010). Os envolvidos no processo de discussão de currículos diferenciados devem estar conscientes do "papel da escola e do currículo na reprodução da estrutura social e, ainda preocupados em construir uma escola e um currículo afinados com os interesses dos oprimidos" (MOREIRA E SILVA, 2002, p. 14). No caso de uma educação quilombola há, claramente, enfrentamentos que passam pelo currículo na medida em que o projeto por uma educação passa por conhecimentos e saberes que estão fora do currículo prescritivo. É necessário discutir o currículo como um território em disputa, sabendo que a luta será muito difícil para desconstruir um currículo tradicional e construir currículos múltiplos. 
Ou seja, que personifiquem as diferenças dos vários territórios ou realidades socioculturais. As DCNs quilombolas abrem precedentes para uma possível ruptura, porém, é preciso traçar caminhos. A Educadora B segue expressando as dificuldades de se discutir currículos diferenciados:

Por que temos tanta dificuldade? A gente nem se vê como construtores de um currículo, quanto mais construtores de um currículo com qualquer comunidade. Isso é inconsciente. Mesmo a gente vê o currículo como algo que está dado, está colocado e nos transcende. Às vezes temos dificuldade em entender que o currículo nada mais é do que opção. Não existe conhecimento Universal. O que está ali são opções. Aquilo está ali porque um milhão de outras coisas está fora. Para pensar qualquer currículo a gente precisa pensar em opções. A primeira coisa é ver a escola como um lugar de produção intelectual, tirando o aspecto da desvalorização externa que, não preciso nem falar, nós não nos valorizamos muito, a nossa função, o nosso trabalho e o companheiro. Então, primeiro, é esse resgate de nós como produtores intelectuais, produtores de conhecimento.

Por isso, é importante que os educadores estudem e discutam as teorias do currículo, sobretudo, para desconstruírem a ideia de que o currículo prescritivo é neutro, objetivo e, por isso, o único possível. Os profissionais de educação são peças chave nesse processo. Por isso, como já mencionado anteriormente, precisam se perceber como produtores intelectuais e não apenas reprodutores de conhecimentos sacralizados nas academias. Sem essa perspectiva será muito difícil construir currículos diferenciados já que esses pressupõem, como dito anteriormente, elencar por muitas vezes conhecimentos externos à academia. É importante desconstruir a naturalização dos currículos para que os educadores e a sociedade se empoderem e construam, em conjunto, currículos apropriados a suas realidades sociais.

Santomé (1995) afirma que há, no mundo contemporâneo, uma coisificação do currículo. Ou seja, são fórmulas vazias que são reproduzidas sem uma reflexão dos agentes envolvidos no processo de ensino-aprendizagem que, em muitos casos, não fazem nenhuma relação com as realidades dos alunos. Segundo o autor, os currículos, na sua maioria, se encontram nas mãos de editoras, em forma de materiais didáticos que, por muitas vezes, se constituem como o único material disponível para os professores que passam a reproduzi-los como únicos conteúdos possíveis, reforçando, dessa maneira, uma representação histórica e social de culturas hegemônicas. Esse processo de coisificação dos currículos ocorre, também, por meio de avaliações externas, vestibulares, organização dos espaços, calendários festivos, formação de professores, disciplinas, conteúdos, etc. Essa 
padronização vai cristalizando os currículos e as práticas educacionais como se fossem quase que inatas ao processo educacional. Mas, por outro lado, existem grupos ou indivíduos que militam por outra educação, dentre os quais estão os quilombolas, Movimento Sem Terra (MST), grupos de professores, etc. Estes "estão atuando de forma que podem oferecer importantes bases para um trabalho “contra-hegemônico", também”. (APPLE, 2002, p.47)

Ele é parte de uma tradição seletiva, resultado da seleção de alguém, da visão de algum grupo acerca do que seja conhecimento legítimo. É produto de tensões, conflitos e concessões culturais, políticas e econômicas que organizam e desorganizam um povo. (APPLE, 2002, p. 59)

O atravessamento do currículo por interesses e relações de poder permite também o questionamento da ideia de conhecimento enquanto representação da realidade. Uma vez que o currículo tem um processo histórico marcado por projetos de sociedade, é preciso compreendê-lo como um elemento ativo na formação de identidade particular, coletiva e social. Sendo assim, não está associado apenas a conhecimento, mas também a questão de identidade, ou seja, os currículos são um documento de identidade. (SILVA, 2010). Nesse sentido, a Educadora E está certa quanto à importância de definir: "como será essa escola? Estamos caminhando em relação a isso, mas se não decidirmos que tipo de escola queremos, e como queremos, não conseguiremos construir um currículo específico". Um currículo quilombola precisa exprimir os elementos que constituem essa identidade quilombola:

Nas discussões cotidianas, quando pensamos em currículo pensamos apenas em conhecimento, esquecendo-nos de que o conhecimento que constitui o currículo está inextricavelmente, centralmente, vitalmente, envolvido naquilo que somos, naquilo que nos tornamos: na nossa identidade, na nossa subjetividade. (SILVA, 2010, p.15)

O depoimento da Educadora A assinala caminhos para se pensar um currículo que funcione como um documento de identidade da comunidade quilombola do Bracuí:

O currículo tem que valorizar aquilo que o aluno traz. Não é aquele currículo pronto. Eu acredito na educação quilombola que valoriza a ancestralidade, que valoriza a realidade da Comunidade, naquilo que a comunidade acredita. A oralidade. A educação quilombola é o contrário daquilo que é a educação formal. É valorizar aquilo que é falado, a oralidade. A educação formal valoriza muito o que é escrito. Acho que é isso. É ter um currículo que valorize os saberes que os alunos 
trazem, o que a comunidade tem de mais importante, tem essa questão da horta na comunidade, do meio ambiente, dos griôs, do que eles falam sobre suas histórias, o jongo. Então, o currículo deve valorizar os saberes que a comunidade tem, não o que achamos, mas aquilo que eles acham que é importante.

Como já mencionado, a positivação da história e da cultura dos povos quilombolas passa por transformar essas experiências cotidianas e/ou saberes em um saber escolar a ser aprendido e ensinado. Goodson (2007) contribui para esse trabalho, ao chamar a atenção para a urgência de se pensar o currículo levando em consideração o fato de vivermos em um mundo em constantes mudanças, cada vez mais fragmentado. $\mathrm{O}$ autor sugere um currículo como "identidade narrativa e de gerenciamento da vida". (GOODSON, 2007, p.242). Neste, a trajetória do aluno e os seus planos seriam centrais no processo de aprendizagem. Na contramão, o currículo prescritivo ignora as singularidades, parte do pressuposto de que é possível escolher os conteúdos a serem ensinados de forma imparcial e sistematizá-los para o processo de aprendizagem.

O currículo prescritivo sustenta a mística de que a normatização do universo escolar deve ser campo do governo central, das burocracias educacionais e da comunidade universitária. As escolas seriam distribuidoras dessas determinações, obtendo certa autonomia ou participação caso não questionem as regras ou desafiem a ordem já estabelecida. O custo dessa dinâmica é a manutenção das relações de poder que visam o controle social e a permanência das desigualdades.

o currículo foi basicamente inventado como um conceito para dirigir e controlar o credenciamento dos professores e sua potencial liberdade nas salas de aula. Ao longo dos anos, a aliança entre prescrição e poder foi cuidadosamente fomentada, de forma que o currículo se tornou um mecanismo de reprodução das relações de poder existentes na sociedade. (GOODSON, 2007, p.243).

O currículo desalinhado da realidade dos alunos funciona como um mecanismo que aprofunda a exclusão, pois não trata a diferença por mecanismos apropriados. A uniformização veste uma roupagem democrática, de que o acesso ao mesmo currículo irá equipar os alunos com as mesmas ferramentas para adentrarem nos mais variados setores sociais, nas universidades e no mundo do trabalho. É uma falácia, na medida em que não valoriza a diferença e vem aprofundando as desigualdades sociais. Os mais ricos conseguem a inclusão porque os pais compram o acesso ao currículo. A posição dos pais na sociedade afeta o resultado dos exames que validam os conteúdos de um currículo 
prescritivo. A cada dia é mais comum planos de governos que alinham suas políticas à valorização e imposição de currículos fechados, que não levam em consideração as diferentes experiências vivenciadas individualmente ou coletivamente.

Segundo os seus idealizadores, defensores e a sociedade, que só conhece essa narrativa, o acesso ao currículo prescritivo e o bom desempenho nas avaliações seriam a garantia de uma boa escolarização. O processo de inclusão social estaria completado quando todos tivessem acesso a esse tipo de experiência educacional. Goodson aponta como caminho para desnaturalizar essa narrativa o estudo da história da escolarização, afirmando que "muitos blocos da construção do currículo tradicional são, eles mesmos, mecanismos de exclusão social, e não de inclusão". (Goodson, 2007, p. 244).

Goodson elucidará com o exemplo das disciplinas escolares tradicionais serem escolhidas com base em interesses de determinado grupos sociais ligados aos núcleos de decisão política: "quanto mais poderoso é o grupo social, mais provável que ele vá exercer poder sobre o conhecimento escolar" (Goodson, 2007, p. 245). Se por um lado, a ordem desse jogo pode vir a sofrer alterações em função de pressões sociais por novas demandas que o currículo prescritivo não dá conta, como no caso de uma educação escolar quilombola, por outro, o próprio currículo prescritivo pode sofrer alteração para atender a novas exigências dos detentores do poder político ou econômico.

Um dos caminhos apontados pelo autor para resolver essa crise da educação, seria pensar o currículo como narrativa, ou seja, compreender como a aprendizagem informal pode contribuir para o desenvolvimento escolar. A aprendizagem se alicerçaria em uma "narrativa de vida ou de identidade" (Goodson, 2007, p.248). Essa aprendizagem levaria em consideração o trajeto, a busca e o sonho. Esses elementos são chamados por Goodson de capital narrativo. O capital narrativo vai no sentido oposto ao capital cultural e social que são partes dessa lógica de relações de poder incutidos no currículo prescritivo e em outras formas de reprodução social presentes na escolarização ou na educação.

Dessa forma, ver a aprendizagem como algo ligado à história de vida é entender que ela está situada em um contexto, e que também tem história - tanto em termos de histórias de vida dos indivíduos e histórias e trajetórias das instituições que oferecem oportunidades formais de aprendizagem, como de histórias de 
comunidades e situações em que a aprendizagem informal se desenvolve. (Goodson, 2007, p. 250)

Um currículo narrativo teria o papel de empoderar os alunos com capacidades críticas e autocríticas acerca da realidade em que vivem, permitindo aos mesmos serem reflexivos sobre suas trajetórias e os possíveis caminhos em uma sociedade com rápidas mudanças. Um currículo narrativo está a serviço não da manutenção de relações de poder e exclusão, mas das paixões, missões e propósitos que cada um planeja ou pensa para sua vida. A conclusão de Goodson (2007, p.251) resume muito bem as aspirações do que chama de um currículo narrativo:

Isto seria verdadeiramente um currículo para empoderamento. Passar da aprendizagem prescritiva autoritária e primária para uma aprendizagem narrativa e terciária poderia transformar nossas instituições educacionais e fazê-las cumprir sua antiga promessa de ajudar a mudar o futuro social de seus alunos.

A Liderança A chama a atenção para a necessidade de se pensar o currículo quilombola não apenas de forma acadêmica: "Acho que o professor vai ter que ter outro olhar para além do acadêmico, às vezes o estudo de faculdade é muito reto, não faz curva". O currículo quilombola exige, portanto, "o reconhecimento da existência de uma pluralidade de formas de conhecimento além do conhecimento científico". (SANTOS, 2010, p. 54)

A Liderança B segue apontando elementos para o currículo quilombola que estariam na contramão desses conhecimentos que hoje são afirmados pelos currículos prescritivos:

Eu penso que as danças de matriz africana devem ser um deles, também é importante as pessoas compreenderem o que é uma comunidade quilombola, como surge o movimento quilombola, o direito pela terra e pelo território. Isso é essencial dentro de uma escola quilombola. Outro elemento importante é o Jongo, uma dança de matriz africana. Nós somos uma comunidade Jongueira de raiz, não aprendemos o Jongo com ninguém, isso foi passado pelos mais antigos, com outras comunidades pelo Sudeste do Brasil que mantemos contato. Nossa oralidade, as nossas histórias, nossos pontos de reminiscências, a nossa agricultura, o processo histórico que passamos. (...) Há relações sociais entre as famílias, entender os parentescos. Existem pessoas na própria escola Áurea Pires que são quilombolas e não se entendem como quilombola, nem passam pela cabeça delas. $\mathrm{O}$ bairro inteiro, para nós, é quilombola. São essas coisas mais pontuais que trazem uma carga identitária muito grande e que nos fazem mover esse engenho de saberes.

O depoimento da Liderança B está em consonância com as DCNs no sentido de "promover o fortalecimento da identidade étnico-racial, da história e 
cultura afrobrasileira e africana ressignificada, recriada e reterrritorializada nos territórios quilombolas" (DCNs Quilombola, 2012, Art.35, p. 13). Isso pode contribuir para o empoderamento do negro e quilombola na medida em que passa por uma valorização da cultura afro-brasileira e africana. É fundamental em um currículo quilombola a história de construção dos territórios quilombolas, suas especificidades e semelhanças.

Como já mencionado no Capítulo 2, a oralidade ocupa uma centralidade na medida em que foi por meio da oralidade que todo esse passado chegou ao tempo presente, seja por meio das histórias passadas aos mais jovens, seja por meio do Jongo. Cabe pensar o significado da oralidade para a comunidade, refletir acerca da sua dimensão pedagógica, como o seu uso enquanto ferramenta de transmissão de conhecimento do passado e de outros saberes para os mais jovens:

\begin{abstract}
A questão da oralidade é extremamente importante para as sociedades africanas tradicionais e para as classes populares. A oralidade é fundamental para a apropriação da linguagem escrita. Pecado que por muitas vezes a gente pratica na escola ao não deixar os alunos falarem. Para desenvolver a linguagem escrita você precisa também desenvolver a oralidade. As sociedades tradicionais africanas, tem que ser no plural porque tem uma infinidade muito grande. Não podemos esquecer que também tem a base da escrita na África, que atravessa o Atlântico com esses homens e mulheres e com os árabes que vem para o Brasil, principalmente, na região da Bahia. O próprio ponto riscado que a gente tem dentro da umbanda é uma forma de escrita, é uma forma de simbolização e também atravessa o Atlântico. Assim, a escrita, os símbolos, também estão presentes nas sociedades africanas. É claro que a oralidade, a palavra, tem um peso muito grande. Diferente do que se fala, que a fala não tem o valor da escrita, uma palavra falada tem muito valor dentro da sociedade africana. Isso é importantíssimo. A gente investe pouco nisso. Desqualifica inclusive isso. A escrita sempre esteve identificada nas sociedades europeias, com essa base europeia. Essa escola tem o trabalho de quebrar com essa hierarquia em relação a esses saberes. (Educadora B)
\end{abstract}

O Jongo, por exemplo, se torna imprescindível em um currículo quilombola, pois oriundo da tradição oral, personifica saberes e conhecimentos que precisam ser explorados pelos professores em uma escola quilombola em Santa Rita do Bracuí. Professores não devem apresentar o Jongo aos alunos como apenas uma dança, mas compreender todo o seu potencial pedagógico para a comunidade e compartilhar com os alunos toda essa experiência. Nesse sentido, a Liderança A segue demonstrando o potencial pedagógico do Jongo para a comunidade de Santa Rita do Bracuí: "O Jongo é fortaleza, resistência, diversão, sabedoria, ancestralidade, dança, crença, uma arma, não é uma arma de cortar, é uma arma 
de fortalecimento. "Na mesma direção, a Liderança B exprime a importância do Jongo para a comunidade:

Ele é quem vai pegar a criança, o jovem e vai formar o próprio movimento quilombola. (...) Esses jongueiros e jongueiras estão o tempo todo circulando, levando e trazendo informações pela comunidade inteira, estando em espaço específico com pessoas mais velhas e novas, dentro das festas de casamento, dentro das festas de aniversário, nos encontros na pedra e no campo. O Jongo está nesse espaço como um todo. (...) Então, ele é formador da nossa identidade, de pertencimento ao território, porque ele utiliza desse território para fazer essa teia, essa rede de conexão que essas pessoas constroem através da troca de saberes, para que o Jongueiro venha saber o que é ser quilombola, para que o quilombola possa saber o que é ser jongueiro, para que o quilombola consiga fazer suas práticas ancestrais, saber o ponto do jongo, como se toca um tambor, o tratamento que você tem que ter na roda com os mais velhos. Estamos vendo que hoje em dia as pessoas estão transformando o Jongo em uma mercadoria e estão se esquecendo de toda essa relação social de território, de identidade, de respeito aos mais velhos. Eu falo das comunidades jongueiras de raiz. Os folclóricos enxergam o Jongo como uma dança, que se faz para um turista porque é legalzinho mostrar. No Bracuí isso não acontece, dançamos para mostrar nossa história, nossa história está dentro do Jongo, está embutido no Jongo, está aqui muito antes desse conceito de quilombo.

As histórias expressas nos pontos (versos cantados) são compartilhadas com os mais jovens quando ocorrem as rodas de Jongo, mas também quando esses jongueiros circulam pela comunidade e compartilham essas histórias e seus ensinamentos com a comunidade, nos mais variados espaços do território. Nesse sentido, o jongo está em todo o território e, por isso, é um elemento importante na construção da identidade dessa comunidade. É importante entender que o jongo está sempre sendo ressignificado, na medida em que vão ocorrendo novas experiências históricas. Há uma preocupação dessas comunidades, que salvaguardaram o jongo, de que ele não vire uma mercadoria, ou seja, que seja desprovido dos seus mais variados significados e ensinamentos. A Liderança B enumera alguns dos ensinamentos do jongo que devem fazer parte do currículo para uma educação quilombola:

Os ensinamentos do jongo seriam viver em comunidade, respeitar os mais velhos, conhecer o território, respeitar o outro, ter essa troca de saberes entre as pessoas, porque tudo isso está dentro de uma roda de jongo. Está embutido essa reverência a ancestralidade, esse pensamento de igualdade que a educação escolar quilombola traz.

Nas manifestações culturais, como o Jongo, por exemplo, há uma dimensão corporal da aprendizagem, na qual significados históricos e políticos podem ser compartilhados. E ainda, contribui à problematização das noções de identidade e 
cultura afro-brasileira, sempre referendando seu caráter "relacional, instável, social e historicamente construído, sugerindo a oposição com noções estáticas e essencializadas de identidade e cultura”. (PEREIRA e ROZA, 2012, p.102). Nesse sentido, os autores questionam a ideia de cultura "pura" e autêntica reproduzida de seus ancestrais: "uma identidade negra com as tradições vivas que no Brasil contemporâneo se realizam e se deslocam”. (PEREIRA e ROZA, 2012, p.102). As manifestações culturais podem contribuir para descristalizar o passado, ou seja, percebê-lo como um processo dinâmico e em constante mudança. Dessa maneira, é possível desconstruir imagens estereotipadas e essencializadas. Enfim, é importante apresentar as diversas identidades em um cenário relacional, não como algo cristalizado que apenas ofusca os processos de significação e ressignificação dessas identidades. A Liderança $\mathrm{C}$ sugere caminhos de como desenvolver esse processo curricular:

Com respeito à história local, a cultura, não só do jongo, como de outros saberes, a valorização da identidade negra, ou seja, da negritude. Isso deve ser colocado na escola porque tem crianças negras que não vão saber como lidar com isso. Trabalhar da mesma maneira, isso que eu quero frisar. A escola é quilombola, mas ela não atende só quilombola. Ela atende o bairro como um todo. A escola deve trabalhar a diversidade e a história local também. Ela não atende só quilombola, ela não quer excluir os outros alunos. $\mathrm{O}$ outro aluno é negro e pobre, assim como o quilombola. Trabalhar relações étnico-raciais, trabalhar o racismo, a identidade negra, a negritude. E abraçar todos, falar de gênero, religiosidade. Porque tocou tambor, é macumbeiro, isso é um absurdo!

As escolas precisam, urgentemente, tratar da questão da negritude para que os alunos possam valorizar sua identidade negra e quilombola. Isso pressupõe acolher e dar um novo tratamento aos elementos da cultura afro-brasileira nas salas de aula. "Assim, a diferença que é socialmente marginalizada por um suposto sinal de inferioridade é reelaborada como um ponto central das identidades" (ANDRADE, 2007, p.22). Além de serem identitários, também são multiculturais porque partem da diferença que os formam. Podemos afirmar que as reivindicações assentadas na diferença anseiam por reconhecimento e por garantias de direitos a suas identidades. Portanto, um currículo quilombola deve estar preocupado também em proporcionar o reconhecimento social, lutando contra a produção de preconceitos e significados negativos acerca dos marginalizados, em especial, dos quilombolas. 
A escola pode dar acesso a importantes instrumentos de redistribuição de poder nesta sociedade, tais como o conhecimento sistematizado sobre os direitos, o domínio sobre a língua nacional, o conhecimento sobre a própria história ou o controle sobre os argumentos científicos. Por outro lado, como instrumento de sociabilidade, a escola poderia ajudar também a construir o prestígio social dos grupos socialmente marginalizados, valorizando as diferentes identidades, reconhecendo valores e riqueza em todos os grupos culturais, desconstruindo preconceitos, favorecendo a coexistência pacífica entre todos e reforçando uma convivência mais dialógica entre os diferentes". (ANDRADE, 2009, p.29).

$\mathrm{Na}$ direção de construir esse reconhecimento social, o Educador D afirma que o currículo quilombola deve: "Primeiro, acabar com o eurocentrismo da história”. Ele chama atenção para a importância de se pensar um currículo que permita ao aluno perceber o protagonismo do negro na história: "É o negro assumir o seu papel de protagonismo na história”. Esse protagonismo é importante para a positivação da história do negro que, na sua maioria, é apresentado como submisso.

Trata-se de algo mais subterrâneo, que tem relação com a superação do eurocentrismo e dos fundamentos da hierarquização que durante séculos informou os currículos. Essa superação é um dos emblemas mais caros às lutas pela renovação necessária ao Ensino de História há décadas. (PEREIRA e ROZA, 2012, p. 101).

Sendo assim, "a escola é um instrumento fundamental tanto nas lutas de redistribuição de poder quanto nas de reconhecimento social". (ANDRADE, 2009, p.28). Nessa perspectiva, a Educadora G expõe a relevância de uma educação diferenciada:

\begin{abstract}
Acho que não só do movimento quilombola, mas do indígena, do Caiçara e tantos outros que buscam, considerando que educação é central. Lógico que eu entendo que não existe uma cultura quilombola, indígena, caiçara e eurocêntrica. Não estou falando de uma cultura purista, mas uma cultura que se quer não só relembrar, mas que se quer continuar construindo. Você recebe em sala de aula, digamos, tem que participar de discussões e ensinamentos que vem totalmente de uma cultura colonizadora, totalmente eurocentrada. Isso faz com que você esteja de forma institucionalizada minando qualquer possibilidade dessa cultura, inclusive, de se reconstruir no sentido de continuar existindo e se transformando. Uma educação colonizadora do ponto de vista único que se repassa em toda e qualquer situação. Uma escola que ignora a cultura quilombola politicamente está minando essa Cultura através desse processo.
\end{abstract}

Santomé aponta um caminho para pensar um currículo que seja antimarginalização que, segundo ele, é "aquele que todos os dias do ano letivo, em todas as tarefas acadêmicas e em todos os recursos didáticos estão presentes as culturas silenciadas sobre as quais vimos falando". (1995, p. 172). Nesse sentido é 
que vejo como necessário refletir acerca da ausência da cultura negra do quilombo de Santa Rita do Bracuí no universo escolar e, assim, identificar os elementos que compõe essa estrutura racista impregnada nos currículos escolares.

Tratar esporadicamente dos assuntos referentes à cultura negra é cair em uma proposta de trabalho de um "currículo turístico" (SANTOMÉ, 1995, p. 173). Segundo o autor, o currículo turístico pode ser percebido nas seguintes situações: trivialização (tratar o assunto de forma superficial e banal), como souvenir (esporadicamente, poucas tarefas, poucos livros nas bibliotecas sobre a temática), desconexão (apenas vistos em uma determinada data), estereotipagem (imagens estereotipadas para explicar o seu silenciamento) e tergiversação (ocultar ou deformar a história e as origens, como exemplo, podemos citar a teoria da inferioridade genética dos negros):

uma educação libertadora exige que se leve a sério os pontos fortes, experiências, estratégias e valores dos membros dos grupos oprimidos. Implica também ajudálos a analisar e compreender as estruturas sociais que os oprimem para elaborar estratégias e linhas de atuação como probabilidades de êxito. (...) um currículo antimarginalização é aquele em que todos os dias do ano letivo, em todas as tarefas acadêmicas e em todos os recursos didáticos estão presentes as culturas silenciadas sobre as quais vimos falando. (SANTOMÉ, 1995, p. 171- 172)

A Educadora B aponta caminhos para se construir um currículo quilombola anti-marginalização, que seria a partir da trajetória da própria escola, ou seja, dos trabalhos que já são feitos dentro dos pressupostos para uma educação quilombola:
A Feira Frutos da Terra precisa se tornar o nosso eixo curricular. As pessoas precisam chegar na escola e perceber que nessa escola se trabalha com os Frutos da Terra. (...) Temos que pegar o trabalho do cotidiano e começar com essa questão dos Frutos da Terra desde o início do ano para ver se conseguimos transformar isso em algo maior, que agregue mais, ajude a discutir mais a escola e o movimento dentro da questão étnico-racial. Fazemos tanta coisa, mas parece que não fazemos nada. É importante que o trabalho seja orgânico, tenha continuidade e desenraize dessa produção curricular. Tem um autor chamado Mauríce Tardif que fala sobre o saber na prática. Tudo é construído na prática. Você tem que partir do que já acontece, do que o grupo já produz, o que o grupo já faz. Não adianta querermos apostar em outras coisas, temos que valorizar o que é feito.

A Educadora destaca o desafio de pensar a educação quilombola para além do evento. Ou seja, não mais como um currículo turístico, onde o aluno terá acesso aos temas da modalidade apenas em datas ou eventos. Mas que os eventos sejam transformados em eixos curriculares. Dessa forma, deixa de serem eventos 
e passam a serem os norteadores de todas as práticas pedagógicas. Um dos caminhos sugeridos seria transformar a "Feira Frutos da Terra" - evento que ocorre uma vez ao ano na escola, com um tema ligado às temáticas da cultura e história local - nesse eixo curricular para uma educação quilombola na Escola Áurea Pires da Gama. Pereira e Roza vão ao encontro quando sinalizam para o perigo de se criar um currículo marcado pela estereotipia. Ou seja, os temas hegemônicos são tratados cotidianamente, enquanto os temas oriundos das minorias são apresentados apenas em eventos, deslocados de um processo que só poderá ser compreendido se for apresentado dentro de sua dinâmica e com as devidas pontes com o tempo presente.

A utilização de datas, de algum modo, quebra o silenciamento, podendo se dar até mesmo como uma ressignificação importante em relação à trajetória, à história e à cultura negra. Porém, não se alcança o objeto de valorização da cultura negra e do negro apenas com essas datas. No Bracuí, a história do Quilombo e de suas práticas culturais é apresentada em momentos específicos, porém, não se percebe entre os alunos e os demais moradores do bairro, o respeito ou a compreensão mais aprofundados da história local. Isto demonstra que essa prática pedagógica não tem sido efetiva no combate ao racismo e nem uma valorização da história do negro e de suas manifestações advindas do Quilombo do Bracuí. A maioria dos alunos continua associando jongo a macumba e negando, por muitas vezes, sua própria identidade enquanto negro e/ou quilombola. O depoimento da Liderança B vai na direção de como pensar esse currículo quilombola:

Tinha que primeiro derrubar, figuradamente, as paredes da escola. Eu penso que educação escolar quilombola não se faz dentro da sala de aula apenas. Os estudantes e educadores precisam rodar na comunidade quilombola, até porque, é isso, quando a gente fala de quilombo a gente fala de território quilombola. Então, precisamos conhecer esse território, precisamos andar por ele, usá-lo como exemplo, fazer ele ser vivo dentro dessa escola para uma educação escolar quilombola. Para validá-la de fato, é preciso sair dessas paredes da escola, porque assim você consegue atingir de fato os estudantes que moram naquela localidade e você consegue fazer de fato com que aqueles alunos não quilombolas possam conhecer uma realidade que ele não conhece, que, às vezes, ele nem consegue imaginar porque isso não é palpável para ele, por ele não fazer parte desse cotidiano e que não é falado em lugar nenhum dentro da escola. É aquilo: você pegar as disciplinas e trazer para realidade do próprio estudante.

A Educadora B menciona a seguir as visitas dos alunos ao quilombo como um desses elementos que podem potencializar o currículo: 
Isso tudo exige conhecimento sistematizado. De qualquer maneira não é ficar como as pessoas pensam ficar só estudando história local, indo lá no quilombo e voltando. Não é só isso. Pode ser isso também. Até como uma boa pesquisa de campo porque não é só ir lá e voltar. A gente tem que começar a qualificar um pouco mais as nossas idas, fazer cadernos de campo com os alunos, trabalhar a questão da observação interdisciplinar. Acho que isso é uma grande potência para dentro do currículo. Não desqualifica o currículo, não impede os alunos de aprenderem o conteúdo de Matemática, Física, Química e Biologia. Pelo contrário, as histórias locais são a grande força.

As visitas dos alunos ao Quilombo devem fazer parte do currículo como parte do calendário escolar, não deve funcionar apenas como uma ferramenta isolada à qual alguns professores utilizam em dias e épocas esporádicas. É preciso aproveitar todo o potencial da história local e com isso compreender os espaços de sociabilidade, suas práticas culturais, seus meios de sobrevivência, a importância do território, a trajetória social da comunidade e do bairro, a importância do território como espaço de resistência material, social e cultural. Esses elementos podem engendrar nos alunos uma compreensão maior dos processos históricos. A Educadora B afirma que:

Precisamos entender como nos constituímos para entender como somos hoje. A nossa história aqui no Bracuí é muito forte em relação a isso. Então, não consigo ver essas coisas dissociadas, vejo que estudar história local, a história do território, é ponto de partida.

Essa troca pode contribuir no sentido dos alunos identificarem as marcas da ancestralidade no presente, mas também as mudanças dessas práticas em função das novas demandas do presente. As histórias do tempo presente quando colocadas em diálogo com o passado também podem mostrar esse caráter de mutabilidade da história e da cultura. É imprescindível a compreensão das mudanças e as permanências no tempo/espaço pelas quais passam a cultura e a história, principalmente, no caso do Ensino de História. A Liderança A ressalta a importância da relação histórica entre escola e comunidade, sendo essa experiência imprescindível à construção de um currículo diferenciado:

Houve esse estudo antes, livros que a escola tem, tudo isso já é um caminho andado. O povo sempre gostou de receber as turmas nas casas das famílias. Então, agora com a escola sendo quilombola, podemos voltar com essas práticas de antes. $\mathrm{O}$ conhecimento do local é muito importante. As pessoas vivem ali e às vezes não sabem de nada. É como se você se mudasse para algum lugar e não perguntasse como é que se deram as coisas naquele lugar. Quando a escola leva o aluno no Quilombo, o próprio aluno que mora aqui, passa a conhecer, a valorizar e a estudar 
seu próprio eu, seu próprio eixo, seu próprio território. Ele começa a ver com outros olhos. É como diz o livro: "Bracui, Conhecer para Amar". Tem que levar as crianças para conhecer aquilo que elas já conhecem, assim, elas podem valorizar, por isso, o projeto do livro. Tudo vem trazendo um rastro para uma educação quilombola.

Os projetos com a história local, desenvolvidos ao longo da história da Escola Áurea Pires e da própria comunidade, como o do livro "Bracuí, conhecer para amar"43, são experiências importantes para transformar a história local em eixo do currículo, como sugeriu a Educadora B. No caso do Quilombo do Bracuí, pensar a história local é pensar também a história do negro no Brasil: "A gente abre o livro de história e vê o negro sendo chicoteado, humilhado. (...) É óbvio que é importante saber toda a história de luta, de sacrifício, mas é preciso saber tudo o que trouxeram para o Brasil e fizeram. (Liderança C) Um currículo quilombola deve estar a serviço de desconstruir e construir conceitos, como bem afirma a liderança $\mathrm{B}$ :

Uma educação escolar quilombola serviria para desconstruir conceitos, como a ideia de que tudo que vem, ou é do negro, é ruim, estigmatizado. Que negro não presta. Mostrar as coisas boas. As DCNs quilombolas trazem essas questões. Com as DCNs quilombolas eu posso trabalhar esses conceitos, negritude, território, trabalhando de forma ampla para entender o processo como realmente foi, não só pela fala dos "vencedores", mas sim pelos "vencidos". (...) Eu vejo que essa educação diferenciada promove a autoestima para essa população negra ou população quilombola, mas também do próprio indígena, do branco que está inserido na escola. Acho que toda escola deveria tratar desses assuntos de forma específica, a gente vai criando esses outros espaços para certas pessoas, parecem até guetos. Mas é porque não conseguimos ter acesso às escolas normais, onde passam o ensino bancário onde tudo é igualzinho.

O exemplo prático da Educadora G contribui para a reflexão de como um currículo diferenciado pode ter um efeito positivo sobre os alunos, em especial, negros e quilombolas, quando colocados em uma condição de protagonistas, de valorização:

Às vezes quando a gente usava o exemplo do Quilombo e pedia para eles virem contar, ficava claro como era bacana para eles, porque se sentiam valorizados, como qualquer pessoa quando é colocado ali no centro de um processo que é, inclusive, educativo. Eu acho que considerando que os povos negros são sempre marginalizados, não teria certeza, porque se envolvem questões psicológicas, mas não teria dúvida de que tratar de forma não subalterna inverteria a lógica. Sempre tive a impressão de que tratar do tema do Quilombo de forma pedagógica dava uma

\footnotetext{
43 Segundo a Liderança A o livro, oriundo de um projeto da Escola Áurea Pires da Gama na década de 1990 , teve por objetivo fazer uma pesquisa sobre a história local.
} 
melhora na autoestima, não sei se a palavra seria autoestima, mas parecia que era uma coisa positiva. Em geral, nós temos um currículo que vai usar páginas e mais páginas para falar da Oceania, Europa Ocidental e Oriental e quantas vezes eu vejo aquelas caras de tédio que não sabem de que mundo é esse que nós estamos falando.

Essa dimensão do lugar social dos alunos deve ser pensada para se elaborar um currículo que contribua na luta do movimento negro e quilombola. Do contrário, a educação estará fazendo um desserviço à sociedade na medida em que colabora para perpetuar uma educação excludente. A Liderança A mostra como o entendimento contribui para a desconstrução e construção de identidades:

Quando a palavra quilombola começou era vista como carregada de uma negatividade, as pessoas não querem mais ser negativas. Quando passaram a entender o que é quilombola, ninguém se espanta mais se for chamado de quilombola, nem o outro vai chamar de quilombola para o lado negativo. Então é isso, as pessoas vão se esclarecendo e aquilo vai deixando de ser um bicho papão.

Sendo assim, o currículo quilombola deve ser pensado dentro da perspectiva de uma educação em movimento e para o movimento. Em movimento no sentido de estar se reconstruindo permanentemente na sua relação com a realidade local e para o movimento porque deve estar a serviço de colaborar na luta do movimento quilombola por mais justiça social. A Liderança A destaca a seguir como uma educação quilombola pode contribuir para a luta junto ao movimento quilombola:

Vão dizer que antes a gente não tinha escola para isso, mas nós tínhamos a escola familiar. Hoje as famílias estão mais separadas, tem que cuidar da própria vida. Tendo a escola, ela reúne essas ideias e dá continuidade, passando as ideias na escola. É outro jeito de lutar, de manter a luta que não é tão diferente. O que antes a gente ouvia na casa de um vizinho, na casa de um pai, na casa de um tio ou de qualquer que seja, vai ter que estar na escola que é onde as pessoas estão. Hoje o pai e a mãe não têm mais tempo de ficar, de passar mais coisa para os filhos. Hoje tem pessoas com mais preparação, professores, lideranças, os mais velhos. A nossa ideia de escola quilombola é também ouvir essas pessoas, de ouvir os mais velhos, essa força deles.

É imprescindível em uma educação quilombola tratar das demandas sociais, lutas históricas do movimento quilombola. Um currículo de história deve se alimentar dessas lutas por meio de experiências, em especial, as advindas do próprio movimento via história oral: "A educação vai ajudar a se identificar, e descobrir quem eu sou, de onde eu vim, depois que eu descubro quem são meus ancestrais, aí sim, estarei pronto para saber para onde eu quero ir". (Educador C). 


\section{Considerações Finais:}

A Educação formal também é um espaço de disputa. É preciso compreender que há nos espaços escolares e em seus currículos relações de poder que precisam ser percebidos para que se possa construir a escola voltada à inclusão social. Nesse sentido que os movimentos sociais estiveram frequentemente lutando por uma educação que seja de fato democrática, que acolha as diferenças e potencialize as singularidades na tentativa de estabelecer uma sociedade que respeite a alteridade e se engaje nas lutas para superar as desigualdades sociais. "É a partir do reconhecimento dessas diferenças que o diálogo do currículo pode prosseguir" (APPLE, 2002, p.77).

Não se trata apenas de quebrar o silenciamento, mas de emergir do subterrâneo a história desses agentes históricos que tiveram suas vidas marcadas pela exclusão. Trata-se de quebrar com a hierarquização que permeia os currículos escolares e acadêmicos. Isto poderá ser superado com a revisão dos currículos e práticas docentes, em especial, com mudanças no currículo de história. Nesse sentido, é de suma importância construir práticas pedagógicas e currículos orientados pela pluralidade cultural, sem proselitismo ou imposição identitária, porém, marcadas por uma positivação das diversas identidades, em especial, daquelas subterrâneas, negativizadas, estereotipadas e sub-representadas. Enfim, a Educadora F resume bem os pressupostos de uma educação quilombola:

Uma educação que privilegia o estudo e a preservação dessa Cultura, dessa memória cultural das pessoas descendentes de escravizados que herdaram essas terras. As pessoas que habitam o Bracuí têm essa história e lidam com isso, preservando essa memória. Então, querem uma escola quilombola que valoriza isso e que traga para o contexto do conteúdo escolar. 


\section{Conclusão:}

A educação escolar vem sendo marcada por uma tentativa de homogeneizar o processo de aprendizagem com currículos prescritivos, materiais didáticos comuns e avaliações externas. Ações que pouco levam em consideração a pluralidade cultural local e o diálogo com vários segmentos sociais ligados à educação. O movimento quilombola vai contra esse sistema escolar que visa uniformizar, pois luta por uma educação que pensa as especificidades de um povo, não nega a diversidade cultural e nem hierarquiza as diferenças.

Esse processo de desconstrução e construção não seria possível sem uma reflexão do papel que a educação escolar ocupa, seja para uma educação emancipatória, como uma "ecologia de saberes" (SANTOS, 2010), na qual os conhecimentos dos grupos são apresentados em uma perspectiva horizontal ou, como se apresenta hoje, segundo alguns estudos, negando as diferenças, afirmando uma visão monolítica de sociedade, na qual só é possível viver dentro desse modelo capitalista. Um modelo que silencia, nega, inferioriza, invisibiliza via currículos prescritivos, matérias e práticas docentes do universo escolar.

A educação quilombola propõe uma aprendizagem que leva em conta os saberes da comunidade para uma educação transformadora da realidade social e política. Uma educação libertadora na medida em que não visa uniformizar, mas valorizar esses saberes como algo a ser ensinado e ser aprendido. Portanto, um aprendizado que agrega sentidos, valorização e pertencimento à identidade. A educação escolar "tradicional" não dá conta dessas demandas porque nega a necessidade de um currículo diferenciado, exigindo um conhecimento distante da realidade social dos quilombolas, e ainda, em alguns casos, reforçando o preconceito sobre os saberes tradicionais e silenciando outros saberes.

Uma educação quilombola propõe uma educação que reduza esse distanciamento entre a cultura escolar e a cultura dos estudantes, em especial, quando se trata dos grupos marginalizados. A cultura escolar impõe um padrão, aquele que não se encaixa não obtém o sucesso. Como se sentem nesse contexto, os alunos do quilombo, os negros, os de religiões de origem africana, indígenas, homossexuais e os com alguma necessidade especial? A escola acaba por aprofundar a exclusão ao invés da socialização, fugindo assim de uma das suas principais funções sociais. Biesta (2013), afirma que há uma "necessidade de se 
reconectar com a questão das finalidades na educação.” (p.821) O autor parte do pressuposto que vivemos em uma época de discussões educacionais pautadas na mensuração e por comparações de resultados educacionais. Isso vem orientando boa parte das políticas educacionais no Brasil e no mundo. Essa discussão acaba tendo um reflexo nas práticas educacionais que passam a estar voltadas para atender os resultados exigidos pelo sistema educacional.

O perigo aqui é que acabamos por valorizar o que é medido, em vez de nos envolvermos com a mensuração do que valorizamos. No entanto é isso que deve, em última instância, embasar nossas decisões sobre a orientação da educação, e é por isso que argumentei que devemos ressaltar a questão do que constitui uma boa educação, em vez de apenas prestar atenção à educação eficaz. (BIESTA, 2013, p. 821-822)

O autor também destaca o perigo das estatísticas e dos rankings decidirem pela sociedade e pelos educadores sobre o se constitui como uma boa educação. "Precisamos, portanto, manter a questão da finalidade - a questão do que constitui uma boa educação - em posição central em nossas discussões educacionais e empreendimentos mais amplos.” (BIESTA, 2013, p. 823). Nesse sentido, a educação quilombola é um contraponto à discussão centrada na "eficácia". Os quilombolas partem da premissa do que seria uma boa educação para sua realidade. Nessa discussão, não querem ser espectadores, mas exigem sua participação no processo de construção dessa educação. Afirmam que seus interesses são essenciais para o processo educacional. $\mathrm{O}$ seu protagonismo não se resume a participarem de uma agenda do sistema educacional ou das escolas. Se colocam como produtores de uma pedagogia e de conhecimentos que devem fazer parte das agendas educacionais. Esse protagonismo também inspira outros grupos a lutarem por políticas educacionais diferenciadas.

Enfim, "deveria haver uma discussão constante sobre os propósitos da educação, tanto em relação à educação pública quanto privada.” (BIESTA, 2013, p.817). Fazer essa discussão se coloca como algo bastante difícil, sobretudo, porque a educação serve a interesses de grupos econômicos e também constrói visões de mundo. Porém, os quilombolas conseguiram aprovar as DCNs para uma Educação Escolar Quilombola, um grande passo para a construção de uma outra educação. A luta do Movimento Negro Quilombola, no geral, e do Bracuí, em especifico, deve servir de inspiração para encamparmos uma luta reivindicando a necessidade de pensarmos os propósitos da educação. 
A construção de uma Educação quilombola pressupõe uma construção coletiva, na qual as diferentes vozes da comunidade escolar sejam ouvidas. As entrevistas foram fundamentais na identificação do que esses atores educacionais querem enquanto escola quilombola. Os atores deixam transparecer que um currículo quilombola está para além de propor novos conteúdos pedagógicos, como alguns defendem em algumas reformas educacionais. Uma proposta educacional multicultural deveria estar centrada na pluralidade cultural. O grande ideal seria uma pedagogia crítica que desenvolvesse propostas de como trabalhar a igualdade e o respeito às diversidades. É de suma importância estar atento ao fato de, em nome da igualdade, não tratar as diferenças como uma incapacidade de aprender ou deficiência de aprendizagem, ou seja, tratar como diferentes aqueles que não se enquadram em um determinado padrão, não hierarquizando essas diferenças, mas valorizando de forma horizontal sem perder a sensibilidade para tratar questões que são urgentes, como a questão racial e dos inúmeros grupos que sofrem com a desigualdade material, social e cultural.

O currículo, sobretudo o de História, é de suma importância nesse processo em função de serem desigualdades históricas reproduzidas em currículos marcados por conhecimentos hegemônicos. A revisão dos currículos de história tem reflexo, inclusive, em outras disciplinas por utilizarem o conhecimento histórico como ferramenta de contextualização. Além disso, essas exclusões se alicerçam no silêncio, apagamento e negatividade dos conhecimentos históricos acerca desses grupos. Um currículo de história para uma educação quilombola tem a obrigação de positivar a presença dessas minorias na sociedade, em especial, dos negros e quilombolas. Com isso, abrirá portas, no presente e no futuro, para possibilidades de uma sociedade mais democrática, pluricultural, valorizando as diferentes identidades. 


\section{Referências Bibliográficas e Documentais:}

ABREU, Martha. O caso do Bracuhy. In: Mattos, Hebe. e Schnoor, Eduardo. (orgs.) Resgate: Uma Janela para o Oitocentos. Rio de Janeiro: Top Books, 1995.

ABREU, Martha e Mattos, Hebe. "Remanescentes das comunidades dos Quilombos": memória do cativeiro, patrimônio e direito à reparação. In: "Iberoamericana, XI, 42 (2011), 145-158.

Jongo, registros de uma história. In: Pacheco,

Gustavo e Lara, Silvia Hunold (orgs). Memória do Jongo. As gravações históricas de Stanley J. Stein. Vassouras, 1949. Rio de Janeiro: Folha; Campinas SP: CECULT, 2007.

nacionais para a educação das relações ético-raciais e para o ensino de história e cultura afro-brasileira e africana": uma conversa com historiadores. IN: Estudos Históricos. Rio de Janeiro, vol. 21, n. 41, 2008.

ABREU, Marthae MATTOS, Hebe e DANTAS, Carolina Vianna. Em torno do passado escravista: as ações afirmativas e os historiadores. In: Antíteses. vol. 3, n. 5,2010 .

ALBERTI, Verena e PEREIRA, Amilcar Araujo. História do Movimento Negro no Brasil: depoimentos ao CPDOC. Rio de Janeiro: Pallas; CPDOC-FGV, 2007.

ALMEIDA, Afredo Wagner Berno de. Terras de Quilombo, Terras Indígenas, "Babaçuais Livres", "Castanhais do Povo", Faxinais e Fundos de Pasto: Terras Tradicionalmente Ocupadas.Manaus: PPGSCA-UFAM, 2006.

ANDERSON, Benedict R. Comunidades imaginadas: reflexões sobre a origem e a difusão do nacionalismo. São Paulo: Companhia das letras, 2008.

ANDRADE, Marcelo (org.). A Diferença que desafia a escola: A prática pedagógica e a perspectiva intercultural. Rio de Janeiro: Quartet, 2009.

APLLE, Michael W. A política do conhecimento oficial: Faz sentido um currículo Nacional? In: In: MOREIRA, Antônio Flávio e SILVA, Tomaz Tadeu da (org.). Currículo, Cultura e Sociedade. $8^{\mathrm{a}}$ ed. São Paulo: Cordez, 2005.

Repensando ideologia e currículo. In: Currículo, Cultura e Sociedade. 7. ed. São Paulo: Cortez, 2002.

ARROYO, Miguel G. Outros Sujeitos, Outras Pedagogias. In: Outros Sujeitos, Outras Pedagogias. Petrópolis, RJ: Vozes, 2012.

Pedagogias em Movimento - o que temos a aprender dos movimentos sociais? In: currículo sem fronteiras, v.3, n. 1, p. 28-29, jan/jun 2003. 
ARRUTI, José Maurício. Quilombos. In: Raça: novas perspectivas antropológicas. 2 ed. rev. Salvador: ABA: EDUFBA, 2008.

A Emergência dos "remanescentes": notas para um diálogo entre indígenas e quilombolas. MANA. 3(2):7-38, 1997.

Da 'educação do campo' à 'educação quilombola': Identidade, conceitos, números, comparações e problemas.2012 In: http://lapfpuc-rio.blogspot.com.br/ (O último acesso ao texto foi realizado no dia 01/07/2017).

BARATA, Jade Prata Bueno. Educação entre alienação e emancipação: Um estudo de caso do Quilombo Campinho da Independência. Dissertação (mestrado) - Universidade de Pós-Graduação em Psicossologia de Comunidades e Ecologia Social - EICOS, 2013.

BERNARDO, Délcio José. Jongo: Uma Didática a Caminho da Escola. In: SILVA, René Marc da Costa. Cultura Popular e Educação. Brasília: Ministério da Educação, Secretaria de Educação a Distância, 2008.

BIESTA, Gert. Boa Educação na Era da Mensuração. In: Cadernos de Pesquisa. v. 42 n.147. p. 808-825. set./dez. 2012.

BITTENCOURT, Circe Maria Fernandes. Ensino de História: Fundamentos e métodos. 4 ed. São Paulo: Cortez, 2011.

BOSI, Ecléa. Memória-sonho e memória-trabalho. In: Memória e sociedade: lembranças de velhos. São Paulo: Companhia das Letras, 1994. $4^{a}$ edição. p. 4170.]

Tempo de lembrar. In: Memória e sociedade: lembranças de velhos. São Paulo: Companhia das Letras, 1994. $4^{\text {a }}$ edição. p. 71-91.

BRAGATTO, Sandra. Descendentes de Escravos em Santa Rita do BracuíMemória e Identidade na Luta pela terra. Dissertação de Mestrado em História. CPDA/UFRRJ, 1997.

CALDART, Roseli Salete. Movimento Sem Terra: Lições de Pedagogia. In: Currículo sem Fronteira, v.3, n. 1, pp.50-59, jan/jun 2003.

CAIMI, Flávia Eloisa. História escolar e memória coletiva: como se ensina? Como se aprende? In: ROCHA, Helenice; MAGALHÃES, Marcelo; GONTIJO, Rebeca (org.). A escrita da história escolar: memória e historiografia. Rio de Janeiro: FGV, 2009. p. 65-79.

CAMACHO, Mariana Moraes. Ser Jovem Quilombola na Comunidade Santa Rita do Bracuí - Angra dos Reis. Disertação de Mestrado em Educação. Universidade Federal Fluminense, 2010. 
CARDOSO, Lourenço e GOMES Lilian. Movimento social Negro e Movimento Quilombola: para uma teoria da tradução. XI Congresso Luso Afro Brasileiro de Ciências Sociais. Diversidade e (Des)igualdades. Salvador, 07 a 10 de agosto de 2011. Universidade Federal da Bahia (UFBA) - PAF I e II, Campus de Ondina.

CATROGA, Fernando. Memória, História e historiografia. Coimbra: Quarteto, 2001.

CARVALHO, Ediléia. "Tem que partir daqui, é da gente": A construção de uma escola "outra" no Quilombo Campinho da Independência. Paraty/RJ: Imperial novo milênio, 2016.

DOMINGUES, Petrônio. Movimento Negro Brasileiro: alguns apontamentos históricos. In: Tempo. ${ }^{\mathbf{o}}$ 23, vol. 12, março de 2007, pp. 100-122.

FERREIRA, Augusta Eulália Ferreira e CASTILHO, Suely Dulce de Castilho. Reflexões sobre a educação escolar quilombola. In: Revista de Pesquisa em Políticas Públicas. Edição nº 03, agosto de 2014.

FERREIRA, Marieta de Moraes (orgs.). Usos e Abusos da História Oral. Rio de Janeiro: Ed. Da Fundação Getúlio Vargas. 1996.

FREIRE, Gilberto. Casa-Grande e Senzala: formação da família brasileira sob o regime da economia patriarcal. São Paulo: Global, 2006, $51^{a}$ edição.

GIROUX, Henry A. e McLaren, Peter. Formação do Professor como uma ContraEsfera Pública: A Pedagogia Radical como uma Forma de Política Cultural. In: MOREIRA, Antônio Flávio e SILVA, Tomaz Tadeu da (org.). Currículo, Cultura e Sociedade. $8^{\mathrm{a}}$ ed. São Paulo: Cordez, 2005.

GIROUX, Henry A. e SIMON, Roger. Cultura popular e pedagogia crítica: A vida cotidiana como base para o conhecimento curricular. In: MOREIRA, Antônio Flávio e SILVA, Tomaz Tadeu da (org.). Currículo, Cultura e Sociedade. $8^{\mathrm{a}}$ ed. São Paulo: Cordez, 2005.

GOODSON, Ivor F. Ensino, Currículo, Narrativa e o Futuro Social. In: Revista Brasileira de Educação. Vol. 12, n.35, maio/ago. 2007, p.241-251.

GOHN, Maria da Glória. Movimentos Sociais na Contemporaneidade. In: Revista Brasileira de Educação, v.16, n.47, maio-ago. 2011.

GONÇALVES, Márcia de Almeida. Entre o local e o nacional: Uma reflexão sobre ética de pertencimento e identidades sociais. Apresentado: IV Seminário Perspectivas do Ensino de História, realizado em Ouro Preto, Minas Gerais, em 2001. http://www.historiadesaogoncalo.pro.br/hp_hsg_lista_artigos.htm (O último acesso ao texto foi realizado no dia 01/07/2017). 
GOMES, Flávio dos Santos. - História de quilombolas: mocambos e comunidades de senzalas no Rio deJaneiro, século XIX. Ed. revisada e ampliada. São Paulo: Companhia das Letras, 2006.

GOMES, Nilma Lino. O Movimento Negro Educador: Saberes Construídos nas Lutas por Emancipação. Petrópolis: Editora Vozes, 2017.

GUIMARÃES, Antônio Sérgio Alfredo. Depois da Democracia Racial. In: Tempo Social, revista de sociologia da USP, v. 18, n.2, 2006.

GUIMARÃES, Antônio Sérgio. Raça e os estudos de relações raciais no Brasil. In: Novos Estudos CEBRAB. São Paulo, n. 54, 1999, p. 147-156.

HALL, Stuart. Da Diáspora: Identidades e Mediações Culturais. Belo Horizonte: UFMG, 2003.

HEYMANN, LucianaQuillet. O "devoir de mémore" na França contemporânea: entre memória, história, legislação e direitos. Anais do III Seminário Pronex "cidania e Direitos", na mesa dever e direito à memória. Rio de janeiro: CPDOC, 2006.

HUYSSEN, Andreas. Resistência à Memória: usos e abusos do esquecimento público. In: Culturas do passado-presente: modernismos, artes visuais, políticas da memória. Rio de Janeiro: Contraponto / MAM, 2014. p. 155-176.

KOSELLECK, Reinhart. Uma história dos conceitos: problemas teóricos e práticos. IN: Estudos Históricos. Rio de janeiro, vol. 5. n. 10, 1992, p. 134-146.

Sobre a Indigência Teórica da Ciência da História. In:

Estratos do Tempo: Estudos Sobre História. RJ: Contraponto, Editora Puc-RJ, 2014.

LOURENÇO, Thiago Campos Pessoa. O império dos Souza Breves nos oitocentos: política e escravidão nas trajetórias dos Comedadores José e Joaquim Breves. Disertação de Mestrado - na Universidade Federal Fluminense, Instituto de Ciências Humanas e Filosofia, Departamento de História, 2010.

MAROUN, Kalyla. Jongo e Educação: A construção de uma identidade quilombola a partir de saberes étnico-culturais do corpo. Tese de Doutorado. Rio de Janeiro: PUC-Rio, Departamento de Educação, 2013.

MATTOS, Hebe e ABREU, Martha e SOUZA, Mirian Alves de e COUTO, Patrícia Brandão. Relatório Antropológico de Caracterização Histórica, Econômica e Sócio-cultural do Quilombo de Santa Rita do Bracuí. Niterói: Universidade Federal Fluminse (UFF)/INCRA-SRRJ, 2009.

MEIHY, José Carlos Sebe Bom. Definindo História Oral e Memória. In: Cadernos CERU. n.5 , série 2, 1994. 
Ministério da Cultura. Dossiê: Jongo no Sudeste. Brasília: IPHAN, 2007.

MONTEIRO, Ana Maria. Os saberes que ensinam: o saber escolar. In: Professores de História: entre saberes e práticas. Rio de Janeiro: Mauad X, 2007. p. 81-111.

MOREIRA, Antonio Flávio e SILVA, Tomaz Tadeu da (orgs). Sociologia e Teoria Crítica do Currículo: Uma introdução. In: Currículo, Cultura e Sociedade. 7. ed. São Paulo: Cortez, 2002.

NÓVOA, Antônio. Pesquisa em Educação Como Processo Dinâmico, Aberto e Imaginativo: Uma Entrevista com Antônio Nóvoa. Educ. Real, Porto Alegre, v.36, n. 2, 533-543, maio/ago. 2011.

O’DWYER, Eliane Cantarino (1995) (Org.): Terra de Quilombo. (Apresentação, 1-2). Rio de Janeiro: Publicação da Associação Brasileira de Antropologia (ABA).

PEREIRA, Júnia Sales e ROZA, Luciano Magela. O Ensino de história entre o dever de memória e o direito à história. In: Revista História. V.1, n. 1, 2012.

PEREIRA, Amilcar Araujo. Por uma autêntica democracia racial? Os movimentos negros nas escolas e nos currículos de história. In: Revista História Hoje. V.1, N ${ }^{\circ}$ 1, 2012, p.111-1128.

POLLAK, Michael. Memória, esquecimento, silêncio. In: Estudos Históricos. Rio de Janeiro, vol. 2, n. 3, 1989.

Memória e identidade social. In: Estudos históricos. Rio de Janeiro, vol. 5, n. 10, 1992, p. 200-212.

PORTELLI, Alessandro. A filosofia e os fatos. Tempo. Rio de Janeiro. vol.1, $\mathrm{n}^{\mathrm{o}}$ 2, 1996. p. 59-72.

. O que faz a história oral diferente? Projeto História. São Paulo. № 14 , fev. 1997, p. 25-39.

. O Massacre de Civitella Val di Chiana (Toscana, 29 de junho de 1944): mito e política, luto e senso comum. In: FERREIRA, Marieta de Moraes. AMADO, Janaína. (orgs.). Usos e Abusos da História Oral. $8^{\text {a }}$ ed. Rio de Janeiro: Ed. FGV, 2006. p. 103-130.

ROSSI, Paolo. Lembrar e esquecer. In: O Passado, a memória, o esquecimento: seis ensaios da história das ideias. São Paulo: Editora UNESP, 2010. p. 15-38.

RÜSEN, Jörn. Razão Histórica: Teoria da História: Os Fundamentos da Ciência Histórica. Brasília: UNB, 2001.

REZNIK, Luís. História local e comunidade: o exercício de memória e a construção de identidades. Apresentado: $6^{a}$ mostra de extensão da UERJ. 
Laureado com o prêmio da mostra de extensão da UERJ, 2002. http://www.historiadesaogoncalo.pro.br/hp_hsg_lista_artigos.htm $\quad(\mathrm{O}$ último acesso do texto foi realizado no dia 01/07/ 2017).

SANTOMÉ, Jurjo Torres. As Culturas negadas e silenciadas no Currículo. In: SILVA, Tomaz Tadeu (org.). Alienígenas na Sala de aula. Petrópolis, RJ: vozes, 1995.

SANTOS, Boaventura de Sousa. Uma sociologia das ausências e uma sociologia das emergências. In: A gramática do tempo: para uma nova cultura política. Para um novo senso comum: a ciência, o direito e a política na transição paradigmática. vol. 4, Porto: Edições Afrontamento, 2006. p. 86-125.

Para além do pensamento abissal: das linhas globais a uma ecologia de saberes. In: Epistemologia do Sul. São Paulo: Editora Cortez, 2010.

SILVA, Petronilha B. Gonçalves e. Aprender, ensinar e relações étnico-raciais no Brasil. In: Educação. Porto Alegre, n. 3 (63), p. 489-506, 2007.

SILVA, Tomaz Tadeu da (org.). Alienígenas na Sala de aula. Petrópolis, RJ: vozes, 1995.

. Documentos de Identidade: Uma introdução às teorias do currículo. Belo Horizonte: Autêntica, 2010.

WANDERLEI, Sonia. Cultura Histórica, mídia e ensino de História: problemas políticos de ensinar e aprender. A História e seus públicos: Anais do Simpósio Internacional de História Pública. São Paulo: USP, 2012, p. 161-169.

Legislação:

MINISTÉRIO da Educação. Diretrizes Curriculares Nacionais para a Educação Escolar Quilombola na Educação Básica. Brasília: MEC, 2012.

MINISTÉRIO da Educação. Diretrizes Curriculares Nacionais para a Educação das Relações Étnico-Raciais e para o Ensino de História e Cultura Afro-brasieleira e Africana. Brasília: MEC, 2005.

BRASIL. Constituição Federal. Brasília: Senado Federal, 1988. Disponível em: http://www.senado.gov.br/atividade/const/con1988/ADC1988_12.07.2016/art_68 .asp

https://www.senado.leg.br/atividade/const/con1988/con1988_15.12.2016/art_215 .asp https://www.senado.leg.br/atividade/const/con1988/CON1988_05.10.1988/art_21 $\underline{6}$. asp

http://www.planalto.gov.br/ccivil_03/decreto/2003/d4887.htm

http://www.planalto.gov.br/ccivil_03/decreto/d3551.htm 
Vídeos:

GOMES, Nilma Lino. Educação Escolar Quilombola. Parte 1 e 2. Publicado em 2 de julho de 2013. IN: https://www.youtube.com/watch?v=MDhbq-NMpAI (acessado no dia 01/07/2017)

Documentários:

Memórias do cativeiro. Direção: Hebe Mattos e Martha Abreu. Rio de Janeiro: UFF, 2005.

Jongos, calangos e folias. Música negra, memória e poesia. Direção: Hebe Mattos e Martha Abreu. Rio de Janeiro: UFF, 2007.

Bracuí: velhas lutas, jovens histórias. Realização: Observatório Jovem do Rio de Janeiro, do Programa de Pós-Graduação em Educação da Universidade Federal Fluminense - UFF, 2007. Direção: Paulo Carrano.

Sou de jongo. Realização: Pontão do Jongo e do Caxambu - UFF, 2009. Produção: Observatório Jovem - UFF. Direção: Paulo Carrano.

Sites:

http://www.cpisp.org.br/terras/asp/terras_tabela.aspx

http://www.cpisp.org.br/terras/ASP/tituladas.asp

www.koinonia.com.br

www.palmares.gov.br

www.historia.uff.br/jongos /

http://www.labhoi.uff.br/

$\underline{\text { www.brevescafe.com.br }}$ 